\title{
\#USAS
}

science for a changing world

\section{Groundwater, Surface-Water, and Water-Chemistry Data, Black Mesa Area, Northeastern Arizona-2009-10}

Prepared in cooperation with the BUREAU OFINDIAN AFFAIRS and the ARIZONA DEPARTMENT OFWATER RESOURCES
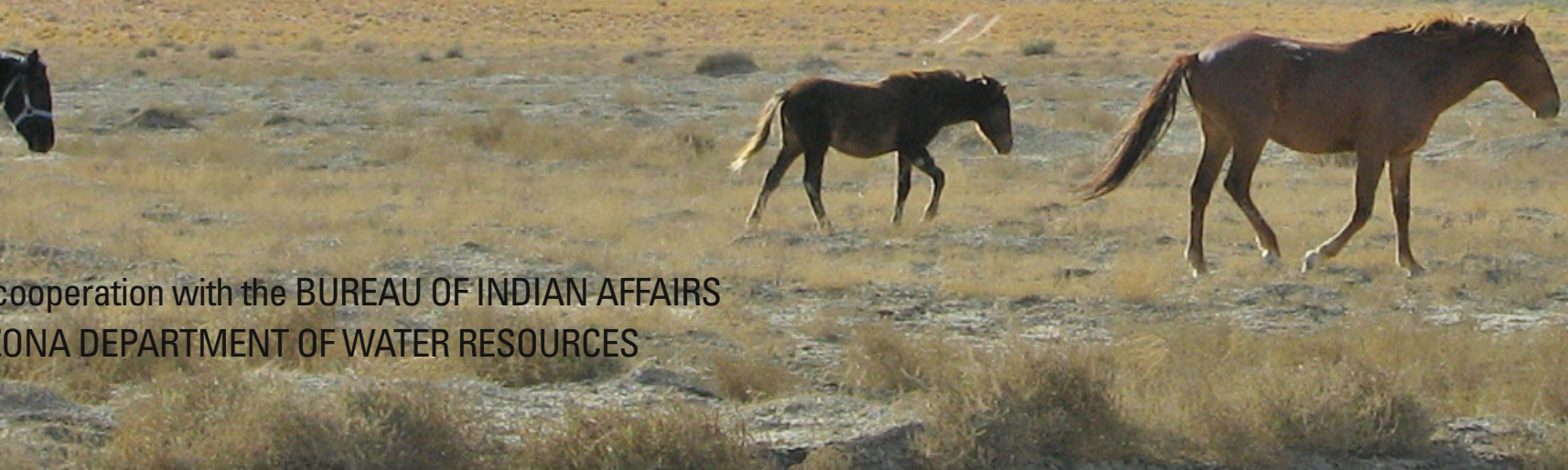

\section{as}

Open-File Report 2011-1198

U.S. Department of the Interior

U.S. Geological Survey 
COVER:

Photograph of the northern cliffs of Black Mesa near Black Mesa observation well \#2, Arizona. (USGS photograph taken by Geoff DeBenedetto.) 


\section{Groundwater, Surface-Water, and Water-Chemistry Data, Black Mesa Area, Northeastern Arizona-2009-10}

By Jamie P. Macy and Christopher R. Brown

Prepared in cooperation with the BUREAU OF INDIAN AFFAIRS

and the ARIZONA DEPARTMENT OFWATER RESOURCES

Open-File Report 2011-1198

U.S. Department of the Interior

U.S. Geological Survey 


\title{
U.S. Department of the Interior \\ KEN SALAZAR, Secretary
}

\author{
U.S. Geological Survey \\ Marcia K. McNutt, Director
}

\section{U.S. Geological Survey, Reston, Virginia: 2011}

This report and any updates to it are available online at:

http://pubs.usgs.gov/of/2011/1198/

For product and ordering information:

World Wide Web: http://www.usgs.gov/pubprod

Telephone: 1-888-ASK-USGS (1-888-275-8747)

For more information on the USGS - the Federal source for science about the Earth,

its natural and living resources, natural hazards, and the environment:

World Wide Web: http://www.usgs.gov/

Telephone: 1-888-ASK-USGS (1-888-275-8747)

Any use of trade, product, or firm names in this publication is for descriptive purposes only and does not imply endorsement by the U.S. Government.

Although this report is in the public domain, permission must be secured from the individual copyright owners to reproduce any copyrighted materials contained within this report. 


\section{Contents}

Abstract
Introduction
Purpose and Scope
Previous Investigations
Hydrologic Data.
Withdrawals from the N Aquifer
$\quad$ Withdrawals in Calendar Year 2009 Compared to Previous Years
$\quad$ Glowmeter Quality Assurance
$\quad$ Spring Discharge from the N Aquifer
Surface-Water Discharge, 2009 water year
$\quad$ Water-Chemistry Data for Wells Completed in the N Aquifer

\section{Figures}

1. Location of study area, Black Mesa area, northeastern Arizona....................................3

2. Rock formations and hydrogeologic units of the Black Mesa area, northeastern Arizona

3. Annual withdrawals from the $\mathrm{N}$ aquifer, Black Mesa area, northeastern Arizona, 1965-2009..

4. Locations of well systems monitored for annual withdrawals from the $\mathrm{N}$ aquifer, Black Mesa area, northeastern Arizona, calendar year 2009........................................11

5. Water-level changes in monitoring program wells completed in the $\mathrm{N}$ aquifer, Black Mesa area, northeastern Arizona ...

6. Water-level changes in $\mathrm{N}$ aquifer wells from the prestress period (prior to 1965) to 2010, Black Mesa area, northeastern Arizona.

7. Observed water-level changes in continuous-record observation wells, BM1-BM6, 1963-2010, N aquifer, Black Mesa area, northeastern Arizona

8. Surface-water and water-chemistry data-collection sites, $\mathrm{N}$ aquifer, Black Mesa area, northeastern Arizona, 2009-10

9. Discharge from $A$, Moenkopi School Spring, $B$, Burro Spring, $C$, Pasture Canyon Spring, and $D$, Unnamed Spring near Dennehotso, N Aquifer, Black Mesa area, northeastern Arizona, 1987-2010

10. Annual average discharge, and annual precipitation at Betatakin, Arizona, Black Mesa area, northeastern Arizona..

11. Median winter flow for November, December, January, and February for water years 1977-2009 for Black Mesa area, northeastern Arizona

12. Water chemistry and distribution of dissolved solids in the $\mathrm{N}$ aquifer, Black Mesa area, northeastern Arizona, 2010 
13. Dissolved-solids concentrations for water samples from selected wells, $\mathrm{N}$ aquifer, Black Mesa area, northeastern Arizona, 1974-2010. 36

14. Concentrations of dissolved solids, chloride, and sulfate for water samples, $\mathrm{N}$ aquifer, Black Mesa area, northeastern Arizona, 1982-2010.

\section{Tables}

1. Withdrawals from the $\mathrm{N}$ aquifer, Black Mesa area, northeastern Arizona, 1965-2009 .........5

2. Tabulated list of progress reports for the Black Mesa monitoring program 1978-2010.........7

3. Identification numbers and names of monitoring program study wells, 2009-10, Black Mesa area, northeastern Arizona.

4. Withdrawals from the $\mathrm{N}$ aquifer by well system, Black Mesa area, northeastern Arizona, calendar year 2009.

5. Total, industrial, and municipal withdrawals from the $\mathrm{N}$ aquifer for discrete time periods during 1965 to 2009, Black Mesa area, northeastern Arizona

6. Flowmeter-test results for municipal wells that are completed in the $\mathrm{N}$ aquifer, Black Mesa area, northeastern Arizona, 2010

7. Water-level changes in monitoring program wells completed in the $\mathrm{N}$ aquifer, Black Mesa area, northeastern Arizona, prestress period to 2010 (calendar year)....12

8. Well-construction characteristics, depth to top of $\mathrm{N}$ aquifer, and type of data collected for wells in monitoring program, Black Mesa area, northeastern Arizona, 2009-10.

9. Median changes in water levels in monitoring-program wells, 2009-10 and prestress period (prior to 1965) to 2010, N aquifer, Black Mesa area, northeastern Arizona

10. Discharge measurements from Moenkopi School Spring, Burro Spring, Pasture Canyon Spring, and Unnamed spring near Dennehotso in the Black Mesa area, northeastern Arizona, 1952-2010

11. Discharge data (daily mean values), Moenkopi Wash at Moenkopi, Arizona, calendar year 2009.

12. Discharge data (daily mean values), Dinnebito Wash near Sand Springs, Arizona, calendar year 2009

13. Discharge data (daily mean values), Polacca Wash near Second Mesa, Arizona, calendar year 2009

14. Discharge data (daily mean values), Pasture Canyon Springs near Tuba City, Arizona, calendar year 2009

15. Period of record for monitoring program streamflow-gaging stations and drainage areas for streamflow-gaging stations, Black Mesa area, northeastern Arizona 
16. Physical properties and chemical analyses of water samples from selected industrial and municipal wells completed in the $\mathrm{N}$ aquifer, Black Mesa area, northeastern Arizona, 2010......

17. Specific conductance and concentrations of selected chemical constituents in water samples from selected industrial and municipal wells completed in the $\mathrm{N}$ aquifer, Black Mesa area, northeastern Arizona, 1974-2010.

18. Physical properties and chemical analyses of water samples from four springs in the Black Mesa area, northeastern Arizona, 2010

19. Specific conductance and concentrations of selected chemical constituents in $\mathrm{N}$ aquifer water samples from four springs in the Black Mesa area, northeastern Arizona, 1948-2010

\section{Conversion Factors and Datums}

\begin{tabular}{lcl}
\hline \multicolumn{1}{c}{ Multiply } & By & \multicolumn{1}{c}{ To obtain } \\
\hline & Length & \\
\hline inch (in.) & 2.54 & centimeter $(\mathrm{cm})$ \\
inch (in.) & 25.4 & millimeter $(\mathrm{mm})$ \\
foot (ft) & 0.3048 & meter $(\mathrm{m})$ \\
mile (mi) & 1.609 & kilometer $(\mathrm{km})$ \\
\hline \multicolumn{3}{c}{ Area } \\
\hline square mile (mi) & 2.590 & \\
\hline \multicolumn{3}{c}{ Volume } \\
\hline acre-foot (acre-ft) & 0.001233 & cubic hectometer $(\mathrm{hm})$ \\
\hline & Flow rate & \\
\hline cubic foot per second (ft/s) & 0.02832 & cubic meter per second $(\mathrm{m} / \mathrm{s})$ \\
gallon per minute $(\mathrm{gal} / \mathrm{min})$ & 0.06309 & liter per second $(\mathrm{L} / \mathrm{s})$ \\
gallon per year $(\mathrm{gal} / \mathrm{yr})$ & 3.785 & liter per year $(\mathrm{L} / \mathrm{yr})$ \\
\hline
\end{tabular}

Temperature in degrees Celsius $\left({ }^{\circ} \mathrm{C}\right)$ may be converted to degrees Fahrenheit $\left({ }^{\circ} \mathrm{F}\right)$ as follows: ${ }^{\circ} \mathrm{F}=\left(1.8 \times{ }^{\circ} \mathrm{C}\right)+32$

Vertical coordinate information is referenced to the National Geodetic Vertical Datum of 1929 (NGVD 29). Altitude, as used in this report, refers to distance above the vertical datum.

Horizontal coordinate information is referenced to the North American Datum of 1927 (NAD 27). Specific conductance is given in microsiemens per centimeter at 25 degrees Celsius

$\left(\mu \mathrm{S} / \mathrm{cm}\right.$ at $\left.25^{\circ} \mathrm{C}\right)$.

Concentrations of chemical constituents in water are given either in milligrams per liter (mg/L) or micrograms per liter $(\mu \mathrm{g} / \mathrm{L})$. 
This page is left intentionally blank. 


\title{
Groundwater, Surface-Water, and Water-Chemistry Data, Black Mesa Area, Northeastern Arizona-2009-10
}

\author{
By Jamie P. Macy and Christopher R. Brown
}

\section{Abstract}

The Navajo $(\mathrm{N})$ aquifer is an extensive aquifer and the primary source of groundwater in the 5,400-square-mile Black Mesa area in northeastern Arizona. Availability of water is an important issue in northeastern Arizona because of continued water requirements for industrial and municipal use by a growing population and because of low precipitation in the arid climate of the Black Mesa area. Precipitation in the area is typically between 6 and 14 inches per year.

The U.S. Geological Survey water-monitoring program in the Black Mesa area began in 1971 and provides information about the long-term effects of groundwater withdrawals from the $\mathrm{N}$ aquifer for industrial and municipal uses. This report presents results of data collected as part of the monitoring program in the Black Mesa area from January 2009 to September 2010. The monitoring program includes measurements of (1) groundwater withdrawals, (2) groundwater levels, (3) spring discharge, (4) surface-water discharge, and (5) groundwater chemistry.

In 2009, total groundwater withdrawals were 4,230 acre-ft, industrial withdrawals were 1,390 acre-ft, and municipal withdrawals were 2,840 acre-ft. Total withdrawals during 2009 were about 42 percent less than total withdrawals in 2005 because of Peabody Western Coal Company's discontinued use of water in a coal slurry used for transporting coal. From 2008 to 2009 total withdrawals increased by 3 percent and industrial withdrawals increased by approximately 15 percent, but total municipal withdrawals decreased by 2 percent.

From 2009 to 2010, annually measured water levels in the Black Mesa area declined in 7 of 16 wells that were available for comparison in the unconfined areas of the $\mathrm{N}$ aquifer, and the median change was 0.1 foot. Water levels declined in 12 of 18 wells measured in the confined area of the aquifer. The median change for the confined area of the aquifer was -0.3 foot. From the prestress period (prior to 1965) to 2010, the median water-level change for 34 wells in both the confined and unconfined area was -13.9 feet. Also, from the prestress period to 2009 , the median water-level changes were -0.8 foot for 16 wells measured in the unconfined areas and -38.7 feet for 18 wells measured in the confined area.

Spring flow was measured at four springs in 2010. Flow fluctuated during the period of record, but a decreasing trend was apparent at Moenkopi School Spring and Pasture Canyon Spring. Discharge at Burro Spring and Unnamed Spring near Dennehotso has remained relatively constant since they were first measured in the 1980s.

Continuous records of surface-water discharge in the Black Mesa area were collected from streamflow-gaging stations at the following sites: Moenkopi Wash at Moenkopi 09401260 (1976 to 2009), Dinnebito Wash near Sand Springs 09401110 (1993 to 2009), Polacca Wash near Second Mesa 09400568 (1994 to 2009), and Pasture Canyon Springs 09401265 (2004 to 2009). Median winter flows (November through February) of each water year were used as an index of the amount of groundwater discharge at the above-named sites. For the period of record of each streamflow-gaging station, the median winter flows have generally remained constant, which suggests no change in groundwater discharge.

In 2010, water samples collected from 11 wells and 4 springs in the Black Mesa area were analyzed for selected chemical constituents, and the results were compared with previous analyses. Concentrations of dissolved solids, chloride, and sulfate have varied at all 11 wells for the period of record, but neither increasing nor decreasing trends over time were found. Dissolved-solids, chloride, and sulfate concentrations increased at Moenkopi School Spring during the more than 12 years of record at that site. Concentrations of dissolved solids, chloride, and sulfate at Pasture Canyon Spring have not varied much since the early 1980 s, and there is no increasing or decreasing trend in those data. Concentrations of dissolved solids, chloride, and sulfate at Burro Spring and Unnamed Spring near Dennehotso have varied for the period of record, but there is no increasing or decreasing trend in the data.

\section{Introduction}

The 5,400-mi² Black Mesa study area in northeastern Arizona contains a diverse topography that includes flat plains, mesas, and incised drainages (fig. 1). Black Mesa is a topographic high at the center of the study area that covers about 2,000 $\mathrm{mi}^{2}$. It has 2,000-foot-high cliffs on its northern and northeastern sides, but it slopes gradually down to the south and southwest. Availability of water is an important issue in 
Groundwater, Surface-Water, and Water-Chemistry Data, Black Mesa Area, Northeastern Arizona, 2009-10

the study area because of continued groundwater withdrawals, the growing population, and average annual precipitation in the arid to semiarid climate that ranges between 6 and 14 in. (U.S. Department of Agriculture, 1999). The Navajo (N) aquifer is the major source of water for industrial and municipal uses in the Black Mesa area. The $\mathrm{N}$ aquifer is composed of three hydraulically connected formations - the Navajo Sandstone, the Kayenta Formation, and the Lukachukai Member of the Wingate Sandstone - that function as a single aquifer (fig. 2).

The $\mathrm{N}$ aquifer is confined under most of Black Mesa, and the overlying stratigraphy limits recharge to this part of the aquifer. The $\mathrm{N}$ aquifer is unconfined in areas surrounding Black Mesa, and most recharge occurs where the Navajo Sandstone is exposed in the area near Shonto (fig. 1) (Lopes and Hoffmann, 1997).

Within the Black Mesa study area, the Navajo Nation and Hopi Tribe are the principal municipal water users, and Peabody Western Coal Company (PWCC) is the principal industrial water user. Withdrawals from the $\mathrm{N}$ aquifer in the Black Mesa area increased fairly consistently from 1965 through 2002 (table 1). PWCC began operating a strip mine in the northern part of the study area in 1968 (fig. 1). In 1982, PWCC sold the largest amount of moisture-adjusted tons of coal to the Mohave generating station and the quantity of water pumped by PWCC increased from about 100 acre-ft in 1968 to a maximum of 4,740 acre-ft in 1982 (John Cochran, Manager of Environmental Hydrology, Peabody Investments Corporation, written commun., 2010). During the same time period, municipal withdrawals grew from about 250 acre-ft in 1968 to 1,830 acre-ft in 1982 .

On December 31, 2005, PWCC reduced pumping of the $\mathrm{N}$ aquifer by approximately 70 percent as a result of discontinued use of a coal slurry pipeline. PWCC planned to continue to pump approximately 1,000 to 1,500 acre-ft per year after 2005, primarily for dust control (table 1).

The members of the Navajo Nation and the Hopi Tribe have been concerned about the long-term effects of withdrawals from the $\mathrm{N}$ aquifer on available groundwater supplies, on stream and spring discharge, and on groundwater chemistry. In 1971, these water-supply concerns led to the establishment of a monitoring program for the water resources in the Black Mesa area by the U.S. Geological Survey (USGS) in cooperation with the Arizona Water Commission, which was the predecessor to the present Arizona Department of Water Resources (ADWR). In 1983, the Bureau of Indian Affairs (BIA) joined the cooperative effort. Since 1983, the Navajo Tribal Utility Authority (NTUA), PWCC, the Hopi Tribe, and the Western Navajo, Chinle, and Hopi Agencies of the BIA have assisted in the collection of hydrologic data.

\section{Purpose and Scope}

This report presents results of groundwater, surfacewater, and water-chemistry monitoring in the Black Mesa area from January 2009 to September 2010. Continuous and periodic groundwater and surface-water data are collected to determine the effects of industrial and municipal withdrawals from the $\mathrm{N}$ aquifer on groundwater levels, stream and spring discharge, and groundwater chemistry. Groundwater data include water levels, spring-discharge rates, and water chemistry. Surface-water data include discharge rates at four continuous-record streamflow-gaging stations. Together, these data are compared with data from 1965 to 2008 to describe the overall status of and change over time of groundwater conditions in the $\mathrm{N}$ aquifer, as well as information on how the aquifer responds to groundwater development stresses. Some statistical analyses of the data are included in this report to examine trends in the data that identify groundwater conditions in the $\mathrm{N}$ aquifer.

\section{Previous Investigations}

Twenty-five progress reports on the Black Mesa area monitoring program have been prepared by the USGS, and they are summarized in table 2. Most of the data from the Black Mesa area monitoring program are contained in these progress reports and in the USGS National Water Information System (NWIS) database (http://waterdata. usgs.gov/az/nwis/).

Stream-discharge and periodic water-quality data collected from Moenkopi Wash before the 1982 water year were published by the USGS (1963-64a, b; 1965-74a, b; and 1976-83). Stream-discharge data from water years 1983 to 2009 for Moenkopi Wash at Moenkopi (09401260), Dinnebito Wash near Sand Springs (09401110), Polacca Wash near Second Mesa (09400568), Laguna Creek at Dennehotso (09379180), and Pasture Canyon Spring (09401265) in the Black Mesa area were published in White and Garrett (1984, 1986, 1987, 1988), Wilson and Garrett (1988, 1989), Boner and others (1989, 1990, 1991, 1992), Smith and others (1993, 1994, 1995, 1996, 1997), Tadayon and others (1998, 1999, 2000, 2001), McCormack and others (2002, 2003), Fisk and others $(2004,2005,2006,2007,2008,2009,2010)$, and online at (http://wdr.water.usgs.gov/wy2009/search.jsp) in the 2009 annual data report. Before the monitoring program, a large data-collection effort in the 1950s resulted in a compilation of well and spring data for the Navajo and Hopi Indian Reservations (Davis and others, 1963).

Many interpretive studies have investigated the hydrology of the Black Mesa area. Cooley and others (1969) made the first comprehensive evaluation of the regional hydrogeology of the Black Mesa area. Eychaner (1983) developed a twodimensional numerical model of groundwater flow in the $\mathrm{N}$ aquifer. Brown and Eychaner (1988) recalibrated Eychaner's model by using a finer grid and by using revised estimates of selected aquifer characteristics. GeoTrans, Inc. (1987) also developed a two-dimensional numerical model of the $\mathrm{N}$ aquifer in the 1980s. In the late 1990s, HSIGeoTrans, Inc., and Waterstone Environmental Hydrology and Engineering (1999) developed a three-dimensional numerical model of the $\mathrm{N}$ aquifer and the overlying Dakota (D) aquifer. 


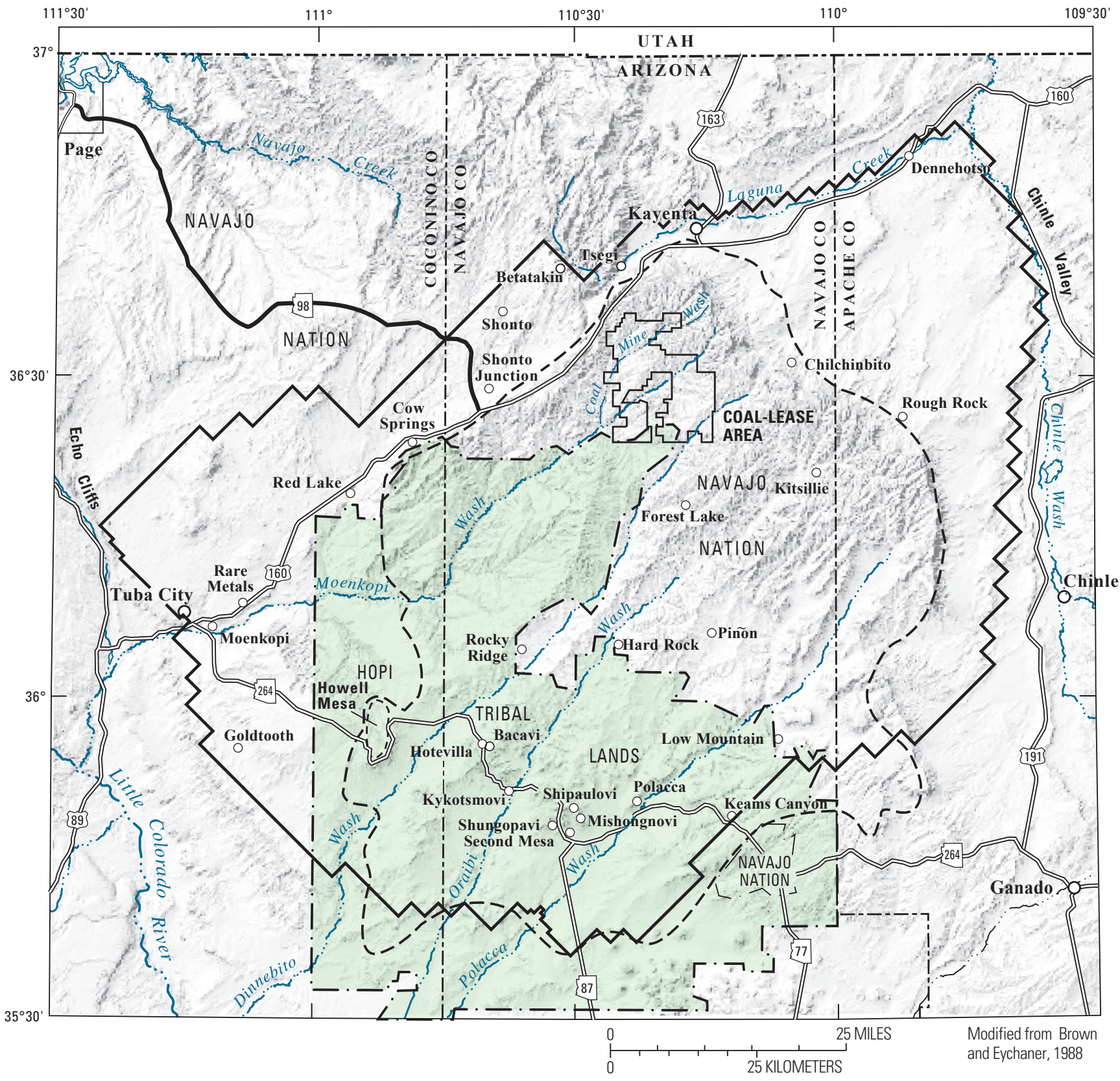

EXPLANATION

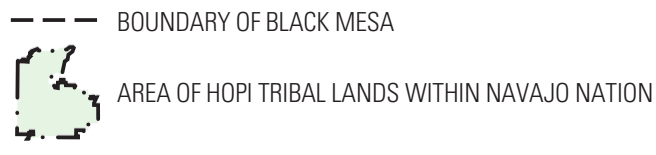

— BOUNDARY OF MATHEMATICAL MODEL_From Brown and Eychaner (1988). The boundary delineates the extent of the $\mathrm{N}$ aquifer monitored in the study area.

Figure 1. Location of study area, Black Mesa area, northeastern Arizona.

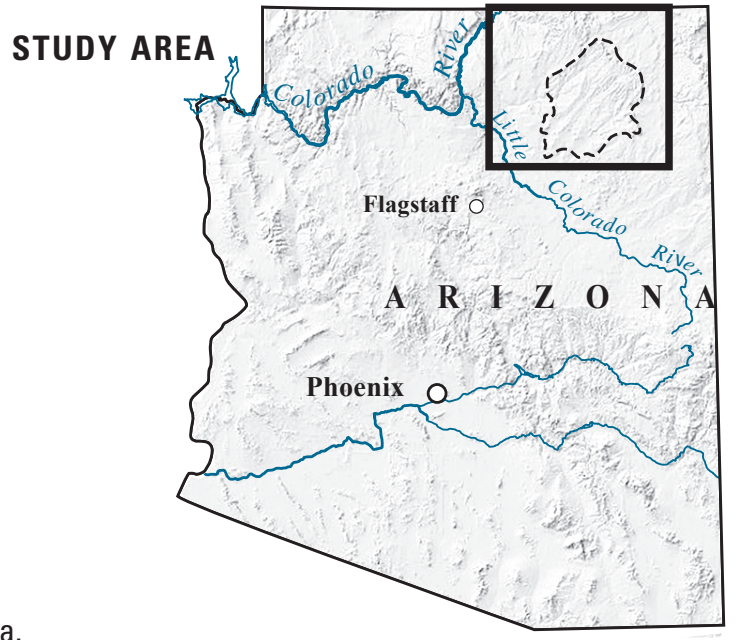




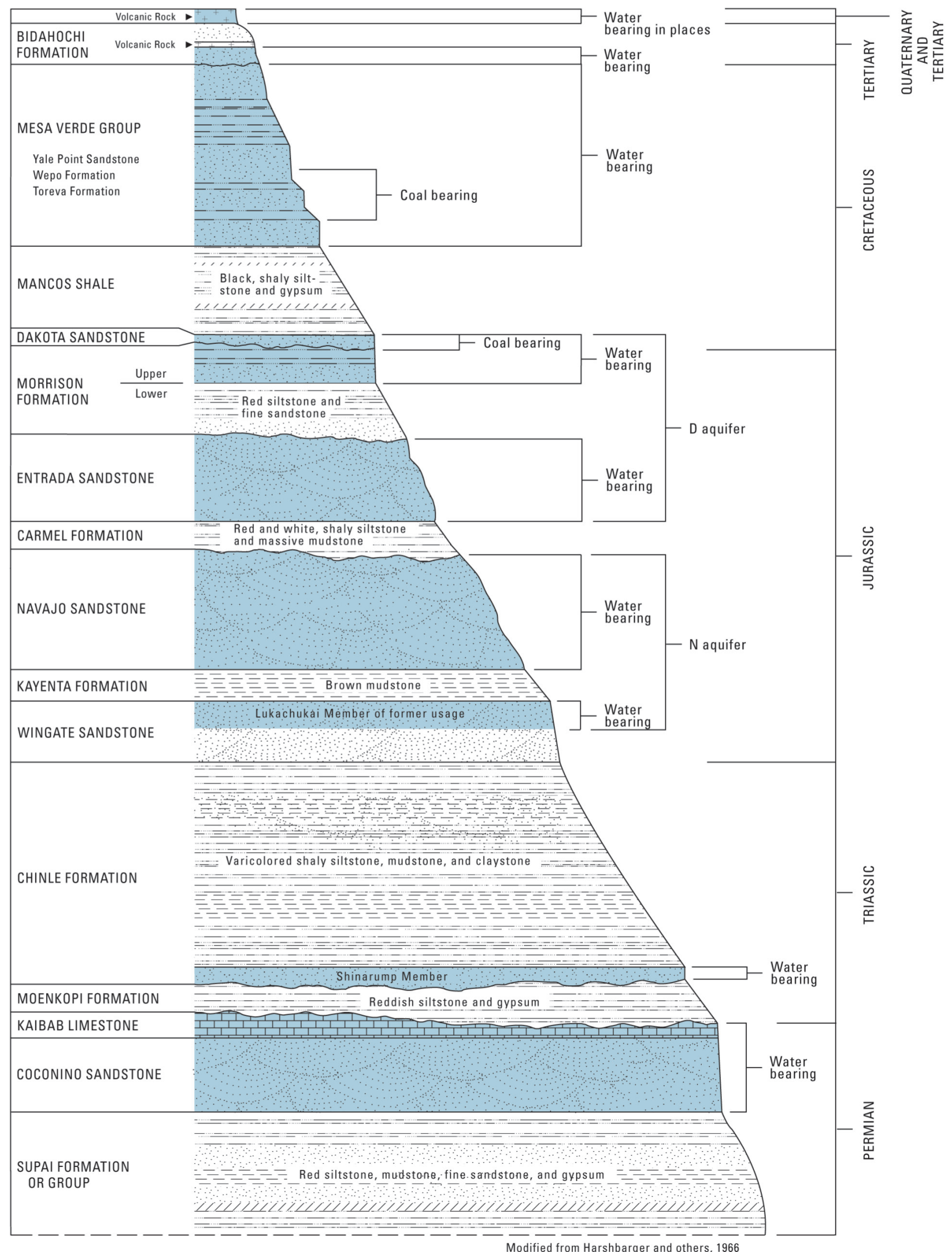

Figure 2. Rock formations and hydrogeologic units of the Black Mesa area, northeastern Arizona (not to scale). The $\mathrm{N}$ aquifer is approximately 1,000 feet thick. 
Table 1. Withdrawals from the N aquifer, Black Mesa area, northeastern Arizona, 1965-2009.

[Values are rounded to nearest 10 acre-feet. Data for 1965-79 from Eychaner (1983).

Total withdrawals in Littin and Monroe (1996) were for the confined area of the aquifer]

\begin{tabular}{|c|c|c|c|c|}
\hline \multirow{2}{*}{$\begin{array}{l}\text { Calendar } \\
\text { Year }\end{array}$} & \multirow{2}{*}{ Industrial1 } & \multicolumn{2}{|c|}{ Municipa|2,3 } & \multirow{2}{*}{$\begin{array}{c}\text { Total } \\
\text { withdrawals }\end{array}$} \\
\hline & & Confined & Unconfined & \\
\hline 1965 & 0 & 50 & 20 & 70 \\
\hline 1966 & 0 & 110 & 30 & 140 \\
\hline 1967 & 0 & 120 & 50 & 170 \\
\hline 1968 & 100 & 150 & 100 & 350 \\
\hline 1969 & 40 & 200 & 100 & 340 \\
\hline 1970 & 740 & 280 & 150 & 1,170 \\
\hline 1971 & 1,900 & 340 & 150 & 2,390 \\
\hline 1972 & 3,680 & 370 & 250 & 4,300 \\
\hline 1973 & 3,520 & 530 & 300 & 4,350 \\
\hline 1974 & 3,830 & 580 & 360 & 4,770 \\
\hline 1975 & 3,500 & 600 & 510 & 4,610 \\
\hline 1976 & 4,180 & 690 & 640 & 5,510 \\
\hline 1977 & 4,090 & 750 & 730 & 5,570 \\
\hline 1978 & 3,000 & 830 & 930 & 4,760 \\
\hline 1979 & 3,500 & 860 & 930 & 5,290 \\
\hline 1980 & 3,540 & 910 & 880 & 5,330 \\
\hline 1981 & 4,010 & 960 & 1,000 & 5,970 \\
\hline 1982 & 4,740 & 870 & 960 & 6,570 \\
\hline 1983 & 4,460 & 1,360 & 1,280 & 7,100 \\
\hline 1984 & 4,170 & 1,070 & 1,400 & 6,640 \\
\hline 1985 & 2,520 & 1,040 & 1,160 & 4,720 \\
\hline 1986 & 4,480 & 970 & 1,260 & 6,710 \\
\hline 1987 & 3,830 & 1,130 & 1,280 & 6,240 \\
\hline 1988 & 4,090 & 1,250 & 1,310 & 6,650 \\
\hline 1989 & 3,450 & 1,070 & 1,400 & 5,920 \\
\hline 1990 & 3,430 & 1,170 & 1,210 & 5,810 \\
\hline 1991 & 4,020 & 1,140 & 1,300 & 6,460 \\
\hline 1992 & 3,820 & 1,180 & 1,410 & 6,410 \\
\hline 1993 & 3,700 & 1,250 & 1,570 & 6,520 \\
\hline 1994 & 4,080 & 1,210 & 1,600 & 6,890 \\
\hline 1995 & 4,340 & 1,220 & 1,510 & 7,070 \\
\hline 1996 & 4,010 & 1,380 & 1,650 & 7,040 \\
\hline 1997 & 4,130 & 1,380 & 1,580 & 7,090 \\
\hline 1998 & 4,030 & 1,440 & 1,590 & 7,060 \\
\hline 1999 & 4,210 & 1,420 & 1,480 & 7,110 \\
\hline 2000 & 4,490 & 1,610 & 1,640 & 7,740 \\
\hline 2001 & 4,530 & 1,490 & 1,660 & 7,680 \\
\hline 2002 & 4,640 & 1,500 & 1,860 & 8,000 \\
\hline 2003 & 4,450 & 1,350 & 1,440 & 7,240 \\
\hline 2004 & 4,370 & 1,240 & 1,600 & 7,210 \\
\hline 2005 & 4,480 & 1,280 & 1,570 & 7,330 \\
\hline 2006 & 1,200 & ${ }^{4} 1,300$ & ${ }^{4} 1,600$ & 44,100 \\
\hline 2007 & 1,170 & 1,460 & 1,640 & 4,270 \\
\hline 2008 & 1,210 & 1,560 & 1,340 & 4,110 \\
\hline 2009 & 1,390 & 1,440 & 1,400 & 4,230 \\
\hline
\end{tabular}

${ }^{1}$ Metered pumpage from the confined part of the aquifer by Peabody Western Coal Company.

${ }^{2}$ Does not include withdrawals from the wells equipped with windmills.

3Includes estimated pumpage 1965-73 and metered pumpage 1974-79 at Tuba City; metered pumpage at Kayenta and estimated pumpage at Chilchinbito, Rough Rock, Piñon, Keams Canyon, and Kykotsmovi before 1980; metered and estimated pumpage furnished by the Navajo Tribal Utility Authority and the Bureau of Indian Affairs and collected by the U.S. Geological Survey, 1980-85; and metered pumpage furnished by the Navajo Tribal Utility Authority, the Bureau of Indian Affairs, various Hopi Village Administrations, and the U.S. Geological Survey, 1986-2009.

${ }^{4}$ NTUA meter data were not available for 2006; therefore, municipal withdrawals are estmated, and total withdrawal uses an estimation in the calculation. 
Kister and Hatchett (1963) made the first comprehensive evaluation of the chemistry of water collected from wells and springs in the Black Mesa area. HSIGeoTrans, Inc. (1993) evaluated the major-ion and isotopic chemistry of the $\mathrm{D}$ and $\mathrm{N}$ aquifers. Lopes and Hoffmann (1997) analyzed groundwater ages, recharge, and hydraulic conductivity of the $\mathrm{N}$ aquifer by using geochemical techniques. Zhu and others (1998) estimated groundwater recharge in the Black Mesa area by using isotopic data and flow estimates from the $\mathrm{N}$ aquifer model developed by GeoTrans, Inc. (1987). Zhu (2000) estimated recharge using advective transport modeling and the same isotopic data from the GeoTrans model. Truini and Longsworth (2003) described the hydrogeology of the $\mathrm{D}$ aquifer and the movement and ages of groundwater in the Black Mesa area by using data from geochemical and isotopic analyses. Truini and Macy (2005) addressed leakage through the confining unit between the $\mathrm{D}$ aquifer and the $\mathrm{N}$ aquifer as part of an investigation of the Carmel Formation.

\section{Hydrologic Data}

In 2009-10, activities of the Black Mesa area monitoring program included metered groundwater withdrawals, measurements of groundwater levels, spring discharge measurements, streamflow gaging, and the collection of water-chemistry samples from wells and springs. All data were collected by the U.S. Geological Survey except withdrawal data from NTUA wells, which were compiled by NTUA personnel. Linear regression and Kendall's tau trend analyses were applied to streamflow data, spring discharge measurements, and waterchemistry samples by using TIBCO Spotfire S+ statistical software. Annual discharge measurements were made at 4 springs, and annual groundwater-level measurements were made at 34 wells. Of those 34 wells, 6 are continuous-recording observation wells that have been upgraded for real-time data telemetry (referred to as "BM observation well" in table 3). The waterlevel data from these six continuous-recording observation wells are available online (http://waterdata.usgs.gov/az/nwis/ $\mathrm{gw})$. Groundwater withdrawal data were compiled during February 2010. The period before appreciable groundwater withdrawals began for mining or municipal purposes (about 1965 ) is referred to in this report as the "prestress period." Spring discharges and groundwater levels were measured from January to June 2010. Groundwater samples were collected from 11 wells and 4 springs in June 2010 and were analyzed for chemical constituents. Annual groundwater-withdrawal data are collected from 28 well systems within the NTUA, BIA, and Hopi municipal systems and the PWCC industrial well field. Identification information for the 34 wells used for water-level measurements and water-quality sampling is shown in table 3. Streamflow data are collected at four USGS gaging stations and are available online (http://waterdata.usgs. gov/az/nwis/rt). All annual data reported in this document are for calendar years beginning January 1 and ending December
31, except for streamflow data which are reported in water years beginning October 1 and ending September 30 .

\section{Withdrawals from the $\mathbf{N}$ Aquifer}

Total annual withdrawals from the $\mathrm{N}$ aquifer are monitored on a continuing basis to determine the effects from industrial and municipal pumping. Withdrawals from the $\mathrm{N}$ aquifer are separated into three categories: (1) industrial withdrawals from the confined area, (2) municipal withdrawals from the confined area, and (3) municipal withdrawals from the unconfined areas. The industrial category includes eight wells in the PWCC well field in the northern Black Mesa area. The BIA, NTUA, and Hopi Tribe operate about 70 municipal wells that are combined into 28 well systems. Information about withdrawals from the $\mathrm{N}$ aquifer is compiled primarily on the basis of metered data from individual wells operated by the BIA, NTUA, and Hopi Tribe (table 4).

Withdrawals from wells equipped with windmills are not measured in this monitoring program and are not included in total withdrawal values reported here. About 270 windmills in the Black Mesa area withdraw water from the $\mathrm{D}$ and $\mathrm{N}$ aquifers primarily for feeding livestock, and the estimated total withdrawal by the windmills is about 65 acre-ft/yr (HSIGeoTrans, Inc., and Waterstone Environmental Hydrology and Engineering, Inc., 1999). The total withdrawal by the windmills is less than 1 percent of the total annual withdrawal from the $\mathrm{N}$ aquifer.

\section{Withdrawals in Calendar Year 2009 Compared to Previous Years}

In 2009, the total groundwater withdrawal from the $\mathrm{N}$ aquifer was about 4,230 acre-ft (table 1). Withdrawals for municipal use from the confined area totaled 1,440 acre-ft. Withdrawals for municipal use from the unconfined areas totaled 1,400 acre- $\mathrm{ft}$. Withdrawals for industrial use totaled 1,390 acre-ft, a 15-percent increase from 2008, and withdrawals for municipal use totaled 2,840 acre-ft, a 2-percent decrease from 2008 (table 5).

Withdrawals from the $\mathrm{N}$ aquifer have varied from 1965 to the present but generally increased from 1965 to 2005 and decreased from 2006 to 2009. Beginning in 2006, Peabody Western Coal Company reduced their pumping by 70 percent, a reduction that is reflected by a decrease in total annual withdrawals from 2005 by about 42 percent (tables 1 and 5, fig. 3). Total withdrawal for the period of record 1965-2009 totaled 235,000 acre-ft; industrial withdrawals were 61 percent and municipal withdrawals were 39 percent of total withdrawals (table 5). During 1965 to 2005, total annual withdrawals increased from 70 to 4,300 acre-ft (table 1); industrial withdrawals were 63 percent and municipal withdrawals were 37 percent of total withdrawals (table 5). A change in the amount of water being pumped from the $\mathrm{N}$ aquifer occurred in 2006; industrial withdrawals accounted for only about 30 percent of the total withdrawals compared to 61 percent the previous year (table 5). From 2006 to 2009, withdrawals totaled 16,710 acre-ft; 
Table 2. Tabulated list of progress reports for the Black Mesa monitoring program 1978-2010.

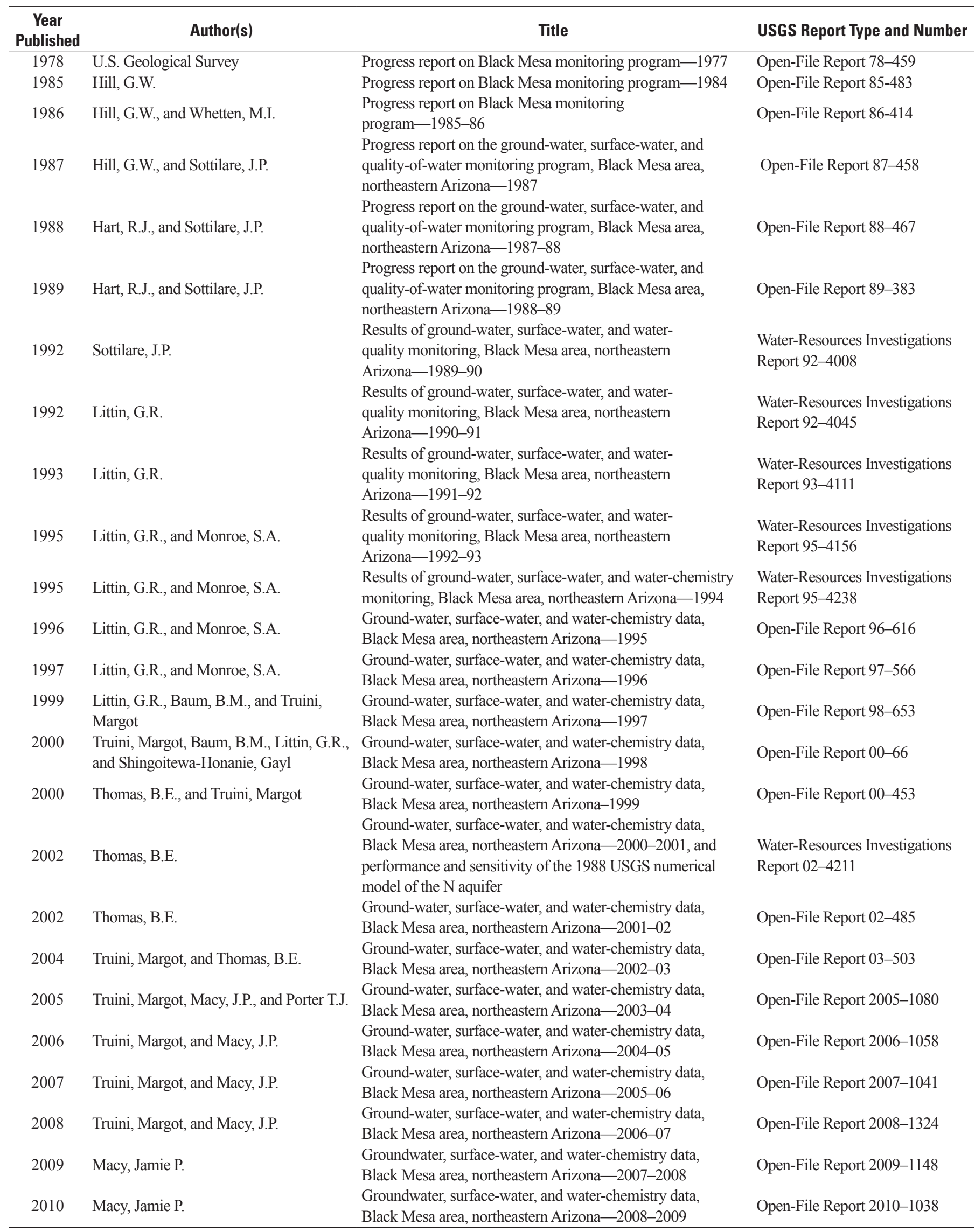


Table 3. Identification numbers and names of monitoring program study wells, 2009-10, Black Mesa area, northeastern Arizona.

[Dashes indicate no data]

\begin{tabular}{|c|c|c|}
\hline $\begin{array}{l}\text { U.S. Geological Survey } \\
\text { identification number }\end{array}$ & Common name or location & $\begin{array}{c}\text { Bureau of } \\
\text { Indian Affairs } \\
\text { site number }\end{array}$ \\
\hline 354749110300101 & Second Mesa PM2 & --- \\
\hline 355023110182701 & Keams Canyon PM2 & --- \\
\hline 355215110375001 & Kykotsmovi PM2 & --- \\
\hline 355230110365801 & Kykotsmovi PM1 & --- \\
\hline 355236110364501 & Kykotsmovi PM3 & --- \\
\hline 355428111084601 & Goldtooth & $3 \mathrm{~A}-28$ \\
\hline 355924110485001 & Howell Mesa & $3 \mathrm{~K}-311$ \\
\hline 360055110304001 & BM observation well 5 & $4 \mathrm{~T}-519$ \\
\hline 360217111122601 & Tuba City & $3 \mathrm{~K}-325$ \\
\hline 360527110122501 & Piñon NTUA 1 & --- \\
\hline 360614110130801 & Piñon PM6 & --- \\
\hline 360734111144801 & Tuba City & $3 \mathrm{~T}-333$ \\
\hline 360904111140201 & Tuba City NTUA 1 & $3 \mathrm{~T}-508$ \\
\hline 360918111080701 & Tuba City Rare Metals 2 & --- \\
\hline 360924111142201 & Tuba City NTUA 3 & --- \\
\hline 360953111142401 & Tuba City NTUA 4 & $3 \mathrm{~T}-546$ \\
\hline 361225110240701 & BM observation well 6 & --- \\
\hline 361737110180301 & Forest Lake NTUA 1 & $4 \mathrm{~T}-523$ \\
\hline 361832109462701 & Rough Rock & 10T-258 \\
\hline 362043110030501 & Kits'iili NTUA 2 & --- \\
\hline 362149109463301 & Rough Rock & 10R-111 \\
\hline 362418109514601 & Rough Rock PM5 & --- \\
\hline 362406110563201 & White Mesa Arch & $1 \mathrm{~K}-214$ \\
\hline 362823109463101 & Rough Rock & 10R-119 \\
\hline 362936109564101 & BM observation well 1 & $8 \mathrm{~T}-537$ \\
\hline 363005110250901 & Peabody 2 & -- \\
\hline 363007110221201 & Peabody 6 & --- \\
\hline 363013109584901 & Sweetwater Mesa & $8 \mathrm{~K}-443$ \\
\hline 363103109445201 & Rough Rock & $9 Y-95$ \\
\hline 363143110355001 & BM observation well 4 & $2 \mathrm{~T}-514$ \\
\hline 363213110342001 & Shonto Southeast & $2 \mathrm{~K}-301$ \\
\hline 363232109465601 & Rough Rock & 9Y-92 \\
\hline 363309110420501 & Shonto & $2 \mathrm{~K}-300$ \\
\hline 363423110305501 & Shonto Southeast & $2 \mathrm{~T}-502$ \\
\hline 363558110392501 & Shonto PM2 & --- \\
\hline 363727110274501 & Long House Valley & $8 \mathrm{~T}-510$ \\
\hline 363850110100801 & BM observation well 2 & $8 \mathrm{~T}-538$ \\
\hline 364034110240001 & Marsh Pass & $8 \mathrm{~T}-522$ \\
\hline 364226110171701 & Kayenta West & $8 \mathrm{~T}-541$ \\
\hline 364248109514601 & Northeast Rough Rock & $8 \mathrm{~A}-180$ \\
\hline 364338110154601 & BM observation well 3 & $8 \mathrm{~T}-500$ \\
\hline 364344110151201 & Kayenta PM2 & $8 A-295$ \\
\hline 365045109504001 & Dennehotso PM2 & --- \\
\hline
\end{tabular}

Table 4. Withdrawals from the $\mathrm{N}$ aquifer by well system, Black Mesa area, northeastern Arizona, calendar year 2009.

[Withdrawals, in acre-feet, are from flowmeter measurements. BIA, Bureau of Indian Affairs; NTUA, Navajo Tribal Utility Authority; USGS, U.S. Geological Survey; Peabody, Peabody Western Coal Company; Hopi, Hopi Village Administrations]

\begin{tabular}{llccc}
\hline $\begin{array}{c}\text { Well system } \\
\text { (one or more } \\
\text { wells) }\end{array}$ & Owner & $\begin{array}{c}\text { Source of } \\
\text { data }\end{array}$ & $\begin{array}{c}\text { Withdrawals } \\
\text { Confined } \\
\text { aquifer }\end{array}$ & $\begin{array}{c}\text { Unconfined } \\
\text { aquifer }\end{array}$ \\
\hline Chilchinbito & BIA & USGS/BIA & 3.3 & \\
Dennehotso & BIA & USGS/BIA & & 17.5 \\
Hopi High & BIA & USGS/BIA & 18.5 & \\
\end{tabular}

School

Hotevilla

Kayenta

BIA

USGS/BIA

19.4

Keams Canyon

BIA

USGS/BIA

38.7

Low Mountain

BIA

USGS/BIA

257.3

BIA

USGS/BIA

USGS/BIA

Piñon

BIA

USGS/BIA

5.2

Rocky Ridge

BIA

USGS/BIA

${ }^{1} 0$

10

Rough Rock

BIA

USGS/BIA

6.4

Second Mesa

BIA

USGS/BIA

Shonto

BIA

USGS/BIA

24.3

Tuba City

BIA

USGS/BIA

158.0

Chilchinbito

BIA

USGS/NTUA

Dennehotso

NTUA

USGS/NTUA

Forest Lake

NTUA

USGS/NTUA

Hard Rock

NTUA

USGS/NTUA

Kayenta

NTUA

USGS/NTUA

Kits'iili

Piñon

Red Lake

Rough Rock

NTUA

USGS/NTUA

NTUA

USGSATUA

NTUA

USG/NTUA

NTUA USGS/NTUA

NTUA

USGS/NTUA

NTUA

USGS/NTUA

Shonto Junction

NTUA

USGS/NTUA

Tuba City

NTUA

USGS/NTUA

Mine Well Field

Bacavi

Hopi

Peabody

Hopi Civic

Hopi

USGS/Hopi

1,390

24.7

Center

Hopi Cultural

Hopi

USGS/Hopi

6.8

Center

\begin{tabular}{lllrl} 
Kykotsmovi & Hopi & USGS/Hopi & 41.5 & \\
Mishongnovi & Hopi & USGS/Hopi & 6.3 & \\
Moenkopi & Hopi & USGS/Hopi & & 229.6 \\
Polacca & Hopi & USGS/Hopi & 188 & \\
Shipaulovi & Hopi & USGS/Hopi & 21.9 & \\
Shungopovi & Hopi & USGS/Hopi & 9.9 & \\
\hline
\end{tabular}

${ }^{1}$ Well taken out of service.

${ }^{2}$ Estimated value due to partial record. 
Table 5. Total, industrial, and municipal withdrawals from the $\mathrm{N}$ aquifer for discrete time periods during 1965 to 2009, Black Mesa area, northeastern Arizona.

\begin{tabular}{lrrrcc}
\hline \multirow{2}{*}{ Period } & \multicolumn{2}{c}{ Withdrawals (acre-feet) } & \multicolumn{2}{c}{ Percent } \\
& \multicolumn{1}{c}{ Total } & Industrial & Municipal & Industrial & Municipal \\
\hline $1965-2009$ & 235,010 & 143,070 & 91,940 & 61 & 39 \\
$1965-2005$ & 218,300 & 138,100 & 80,200 & 63 & 37 \\
$2006-2009$ & 16,710 & 4,970 & 11,740 & 30 & 70 \\
2009 & 4,230 & 1,390 & 2,840 & 33 & 67 \\
\hline
\end{tabular}

industrial withdrawals were 30 percent and municipal withdrawals were 70 percent of total withdrawals (table 5). Total withdrawals in 2009 were 4,230 acre-ft, with 33 percent from industrial withdrawals and 67 percent from municipal withdrawals (table 5).

\section{Flowmeter Quality Assurance}

In an effort to improve and ensure the accuracy of groundwater-withdrawal data, a quality-assurance program was begun in 1985 for withdrawal data from industrial and municipal wells completed in the $\mathrm{N}$ aquifer. Nearly all industrial and municipal wells in the study area are equipped with totalizing flowmeters to measure groundwater withdrawals. The flowmeters on the wells are tested about once every 5 years by measuring withdrawal with a calibrated mechanical flowmeter and comparing the measured withdrawal to the metered withdrawal. For the purpose of this study, the allowable difference between the discharge measured by the permanent totalizing flowmeter and the test meter is 10 percent. A flowmeter that tests outside the 10 percent limit is repaired where possible and is revisited the following year and tested again. Flowmeter testing was done at about 19 percent of the total wells ( 34 wells were visited and 14 wells were tested) during June and July 2010 (table 6). Testing for 2010 was limited to meters that previously were unable to be tested or had percent- difference magnitudes larger than 10 percent in 2009. The median percent difference between pumping rates for the permanent meter and the test meter for all sites tested was -4.6 percent. Values ranged from -16.3 percent at Shonto Junction NTUA 1 to +7.0 percent at Bacavi Village. Three wells had greater than 10-percentdifference magnitudes: Hopi High 2 ( -15.9 percent), Kayenta NTUA 7 (-12.1 percent), and Shonto Junction NTUA 1 (-16.3 percent). No corrections based on these results were applied to pumping data.

\section{Groundwater Levels in the N Aquifer}

Groundwater levels are monitored in the $\mathrm{N}$ aquifer to determine the effects that withdrawals have on the potentiometric surface of the aquifer. Groundwater in the $\mathrm{N}$ aquifer is under confined conditions in the central part of the study area and under unconfined or water-table conditions around the periphery (fig. 4). From the recharge areas near Shonto, groundwater moves radially to the southwest toward Tuba City, to the south toward the Hopi Reservation, and to the east toward Rough Rock and Dennehotso (Eychaner, 1983).

Groundwater levels are measured once a year at the same time of year to limit the effect of seasonal variability. Groundwater levels are compared with levels from previous years to determine short-term changes and also are compared to prestress water levels to determine long-term changes. Only water levels from municipal and stock wells that were not considered to have been recently pumped, affected by nearby pumping, or blocked or obstructed are compared. During March 2010 to May 2010, water levels in all 34 wells having annual measurements met these criteria (table 7). Of the 34 wells, 6 are continuous-recording observation wells, and water levels were measured by electric tape in these 6 wells 3 times between June 2009 and June 2010.

The wells used for water-level measurements are distributed throughout the study area (fig. 5). The wells were constructed

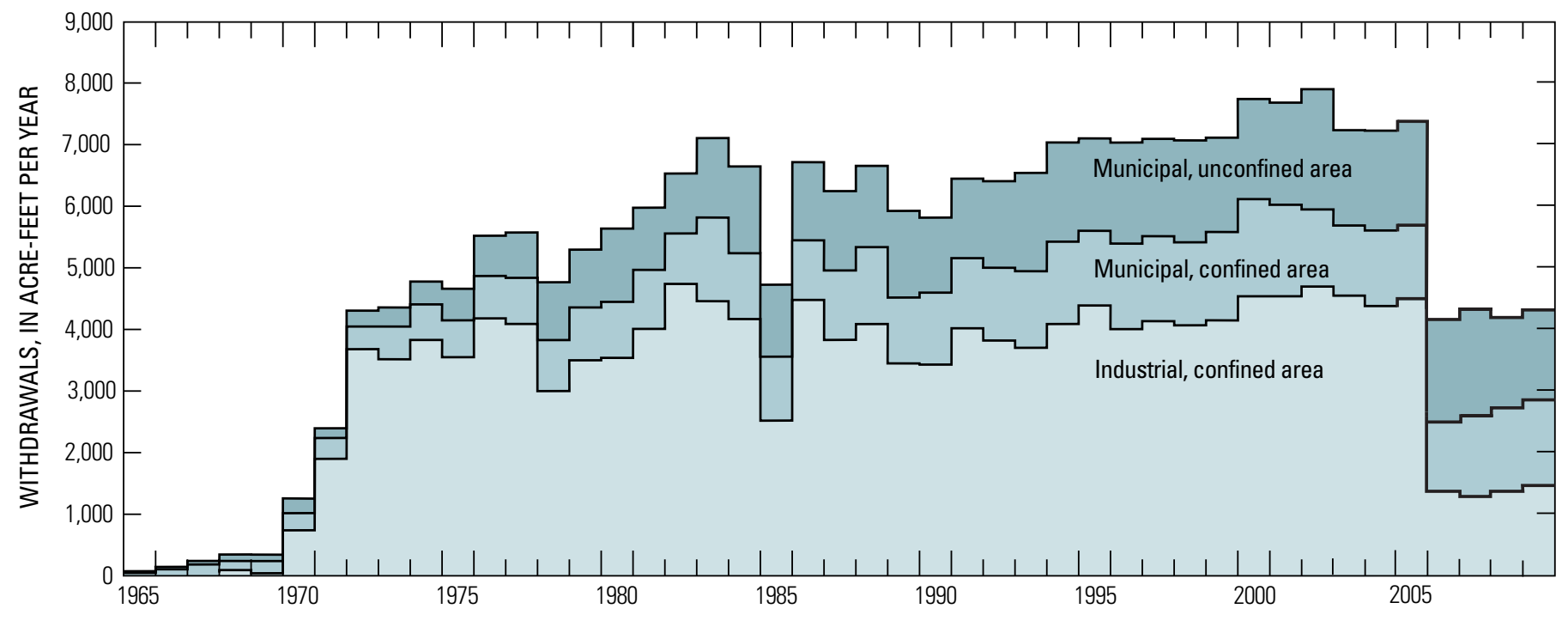

Figure 3. Annual withdrawals from the $\mathrm{N}$ aquifer, Black Mesa area, northeastern Arizona, 1965-2009. 
Table 6. Flowmeter-test results for municipal wells that are completed in the N aquifer, Black Mesa area, northeastern Arizona, 2010.

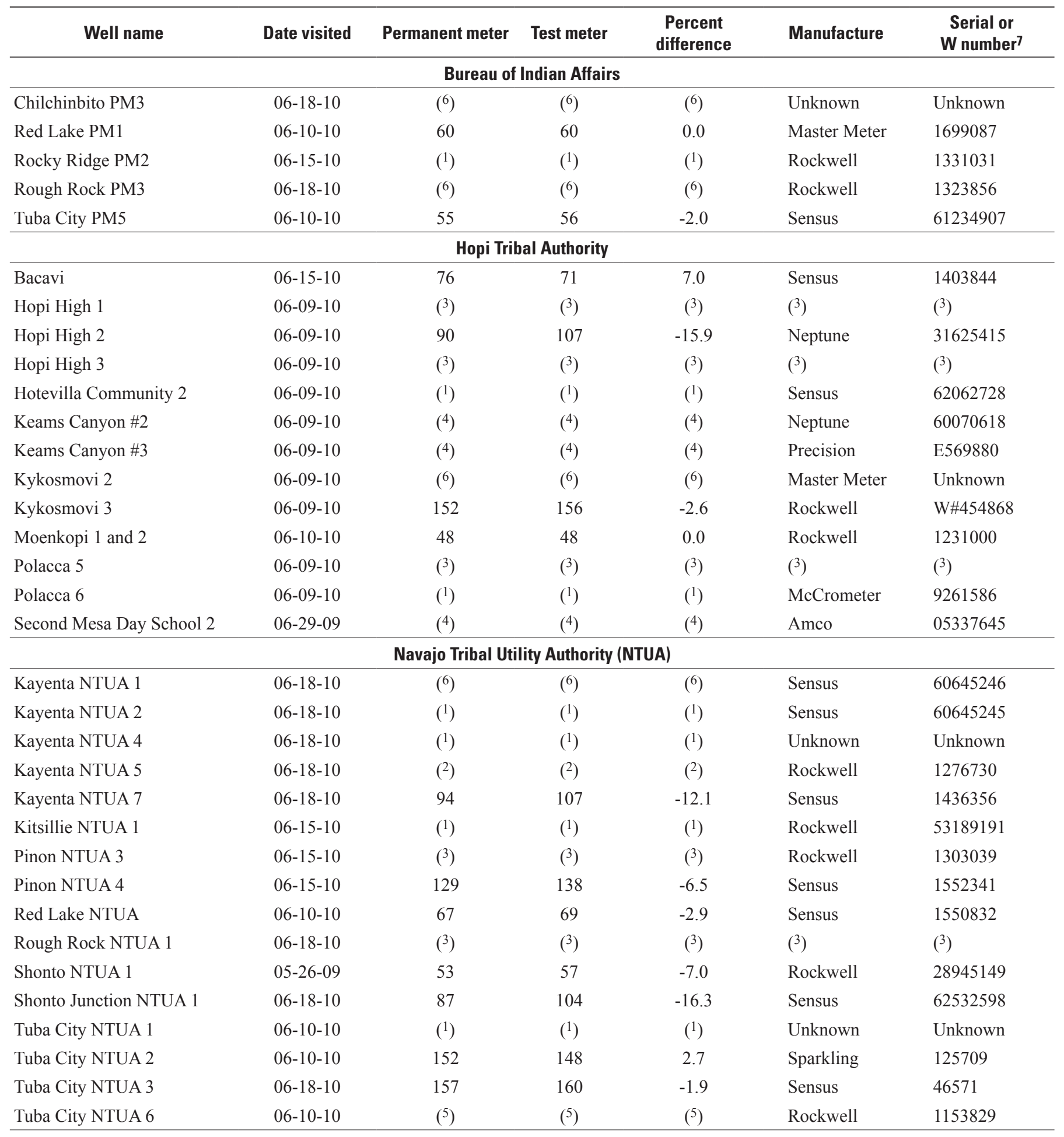

${ }^{1}$ Well inactive.

${ }^{2}$ Meter broken.

${ }^{3}$ Well not in service.

${ }^{4}$ Unable to test.

${ }^{5}$ Flow too high for test meter.

${ }^{6}$ Factory calibrated meter recently installed.

${ }^{7} \mathrm{~W}$ number is a U.S. Geological Survey equipment identification number. 




EXPLANATION

CONFINED AND UNCONFINED CONDITIONS IN THE N AQUIFER WITHIN MODEL BOUNDARY

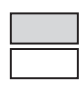

\section{Confined}

Unconfined

APPROXIMATE BOUNDARY BETWEEN CONFINED AND UNCONFINED CONDITIONS From Brown and Eychaner (1988)

- BOUNDARY OF MATHEMATICAL MODELFrom Brown and Eychaner (1988)

\section{WELL-SYSTEM OWNER}

- Bureau of Indian Affairs

- Navajo Tribal Utility Authority

(D Hopi Tribe

Peabody Western Coal Company
Piñon (346.7) WITHDRAWALS FROM THE N AQUIFER - Piñon, well-system name; 346.7, total withdrawal in acre-feet for 2009. The total is cumulative at locations served by multiple wells

Figure 4. Locations of well systems monitored for annual withdrawals from the $\mathrm{N}$ aquifer, Black Mesa area, northeastern Arizona, calendar year 2009. 
between 1934 and 1993, the total well depths range from $107 \mathrm{ft}$ near Dennehotso (8A-180) to 3,636 ft near PWCC, and depths to the top of the $\mathrm{N}$ aquifer range from $0 \mathrm{ft}$ near Tuba City to 2,205 ft at Kits'illi NTUA 2 (table 8).

From 2009 to 2010, water levels decreased in 19 of the 34 wells for which comparisons could be made (table 7). The median water-level change in the 34 wells was $-0.2 \mathrm{ft}$ (table 9).
From 2009 to 2010, water levels declined in 7 of the 16 wells measured in the unconfined parts of the aquifer (table 7), and the median water-level change was $0.1 \mathrm{ft}$ (table 9). Water-level changes in the unconfined part of the aquifer ranged from -18.5 $\mathrm{ft}$ at Tuba City NTUA 1 (3T-508) to $+1.5 \mathrm{ft}$ at Goldtooth (3A28) (table 7). In the confined area, water levels declined in 12 of 18 wells measured from 2009 to 2010 . The median water-level

Table 7. Water-level changes in monitoring program wells completed in the $\mathrm{N}$ aquifer, Black Mesa area, northeastern Arizona, prestress period to 2010 (calendar year).

[Dashes indicate no data. Do., ditto; R, reported from driller's log]

\begin{tabular}{|c|c|c|c|c|c|c|c|}
\hline \multirow[t]{2}{*}{ Common name or location } & \multirow{2}{*}{$\begin{array}{c}\text { Bureau of Indian } \\
\text { Affairs site } \\
\text { number }\end{array}$} & \multicolumn{2}{|c|}{$\begin{array}{l}\text { Change in water level } \\
\text { from preceding year } \\
\text { (feet) }\end{array}$} & \multirow{2}{*}{$\begin{array}{l}\text { Water level } \\
\text { (feet below } \\
\text { land surface), } \\
2010\end{array}$} & \multicolumn{2}{|c|}{$\begin{array}{c}\text { Prestress period water } \\
\text { level }\end{array}$} & \multirow{2}{*}{$\begin{array}{c}\text { Change in } \\
\text { water level } \\
\text { from prestress } \\
\text { period to } 2010 \\
\text { (feet) }\end{array}$} \\
\hline & & 2009 & 2010 & & $\begin{array}{l}\text { Feet below } \\
\text { land surface }\end{array}$ & Date & \\
\hline \multicolumn{8}{|c|}{ Unconfined areas } \\
\hline BM observation well $1^{1}$ & $8 \mathrm{~T}-537$ & -0.4 & 0.2 & 374.4 & 374.0 & $\left({ }^{1}\right)$ & -0.4 \\
\hline BM observation well $4^{1}$ & $2 \mathrm{~T}-514$ & -0.2 & 0.2 & 217.0 & 216.0 & $(1)$ & -1.0 \\
\hline Long House Valley & $8 \mathrm{~T}-510$ & -0.7 & -1.0 & 134.2 & 99.4 & $08-22-67$ & -34.8 \\
\hline Northeast Rough Rock & $8 \mathrm{~A}-180$ & -0.5 & 0.2 & 44.5 & 46.9 & $11-13-53$ & 2.4 \\
\hline Rough Rock & $9 Y-95$ & 2.4 & -1.3 & 106.6 & 119.5 & $08-03-49$ & 12.9 \\
\hline Do. & $9 Y-92$ & 0.7 & -2.2 & 168.2 & 168.8 & $12-13-52$ & 0.6 \\
\hline Shonto & $2 \mathrm{~K}-300$ & -0.2 & 0.0 & 171.4 & 176.5 & $06-13-50$ & 5.1 \\
\hline Tuba City Rare Metals 2 & --- & -0.1 & 0.6 & 49.8 & 57.0 & $09-24-55$ & 7.2 \\
\hline Tuba City NTUA 1 & $3 \mathrm{~T}-508$ & 2.0 & -18.5 & 72.9 & 29.0 & $02-12-69$ & -43.9 \\
\hline Tuba City NTUA 3 & --- & 0.0 & -2.3 & 64.2 & 34.2 & $11-08-71$ & -30.0 \\
\hline Tuba City NTUA 4 & $3 \mathrm{~T}-546$ & -0.3 & -1.3 & 66.3 & 33.7 & $08-06-71$ & -32.6 \\
\hline \multicolumn{8}{|c|}{ Confined area } \\
\hline BM observation well $2^{1}$ & $8 \mathrm{~T}-538$ & -1.2 & -0.2 & 217.8 & 125.0 & $(1)$ & -92.8 \\
\hline BM observation well $3^{1}$ & $8 \mathrm{~T}-500$ & -0.2 & -0.1 & 162.0 & 55.0 & $04-29-63$ & -107.0 \\
\hline BM observation well $5^{1}$ & $4 \mathrm{~T}-519$ & -1.4 & -0.4 & 426.2 & 324.0 & $(1)$ & -102.2 \\
\hline BM observation well $6^{1}$ & --- & 2.2 & 3.8 & 852.6 & 697.0 & $\left({ }^{1}\right)$ & -155.6 \\
\hline Forest Lake NTUA 1 & $4 \mathrm{~T}-523$ & 3.3 & 5.6 & 1180.8 & $1,096 \mathrm{R}$ & $05-21-82$ & -84.8 \\
\hline Marsh Pass & $8 \mathrm{~T}-522$ & 0.1 & 0.0 & 127.6 & 125.5 & $02-07-72$ & -2.1 \\
\hline Piñon PM6 & --- & 0.0 & -3.9 & 908.8 & 743.6 & $05-28-70$ & -165.2 \\
\hline Rough Rock & 10R-119 & -0.2 & 0.1 & 256.7 & 256.6 & $12-02-53$ & -1.1 \\
\hline Do. & $10 \mathrm{~T}-258$ & -0.4 & 0.1 & 309.8 & 301.0 & $04-14-60$ & -8.8 \\
\hline Do. & 10R-111 & 0.2 & -5.4 & 198.7 & 170.0 & $08-04-54$ & -28.7 \\
\hline Sweetwater Mesa & $8 \mathrm{~K}-443$ & 0.4 & -1.9 & 543.8 & 529.4 & $09-26-67$ & -14.4 \\
\hline White Mesa Arch & $1 \mathrm{~K}-214$ & -0.3 & 0.3 & 219.6 & 188.0 & $06-04-53$ & -31.6 \\
\hline
\end{tabular}

${ }^{1}$ Continuous recorder. Prestress water levels were estimated from a ground-water model, except for well BM3 (Brown and Eychaner, 1988).

${ }^{2}$ Cannot be determined because at least one of the water-level measurements is not available.

${ }^{3}$ Water level is the first water level measured after completion of well. 


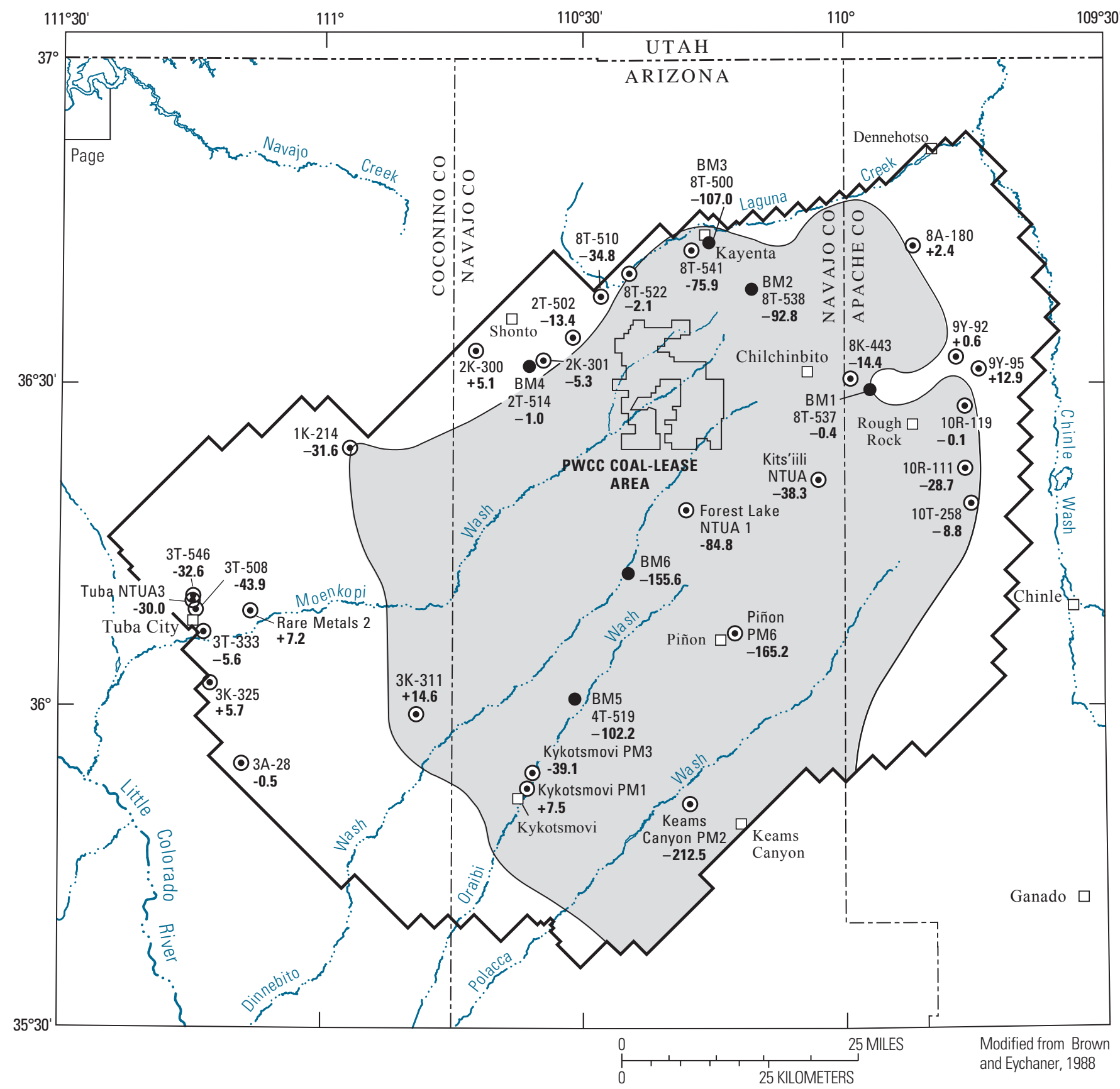

EXPLANATION

CONFINED AND UNCONFINED CONDITIONS IN THE N AQUIFER

Confined area within the boundary
of the mathmatical boundary
Unconfined area within the boundary
of the mathematical boundary
APPROXIMATE BOUNDARY BETWEEN CONFINED
AND UNCONFINED CONDITIONS-
From Brown and Eychaner (1988)
BOUNDARY OF MATHEMATICAL MODEL-

$\odot$ WELL IN WHICH DEPTH TO WATER 2K-300 WAS MEASURED ANNUALLY_First $\mathbf{+ 5 . 1}$ entry, 2K-300, is Bureau of Indian Affairs site number; second entry, $\mathbf{+ 5 . 1}$, is change in water level, in feet, between measurement made during the prestress period and measurement made during 2010. NV, site not visited
CONTINUOUS WATER-LEVEL

BM2 RECORDING SITE (OBSERVATION WELL) 8T-538 MAINTAINED BY THE U.S. GEOLOGICAL

-92.8 SURVEY — First entry, BM2, is U.S. Geological Survey well number; second entry, 8T-538, is Bureau of Indian Affairs site number; third entry, $\mathbf{- 9 2 . 8}$, is change in water level, in feet, from simulated prestress period to 2010

Figure 5. Water-level changes in monitoring program wells completed in the N aquifer, Black Mesa area, northeastern Arizona, prestress period to 2010 (calendar year). 
Table 8. Well-construction characteristics, depth to top of $\mathrm{N}$ aquifer, and type of data collected for wells in monitoring program, Black Mesa area, northeastern Arizona, 2009-10.

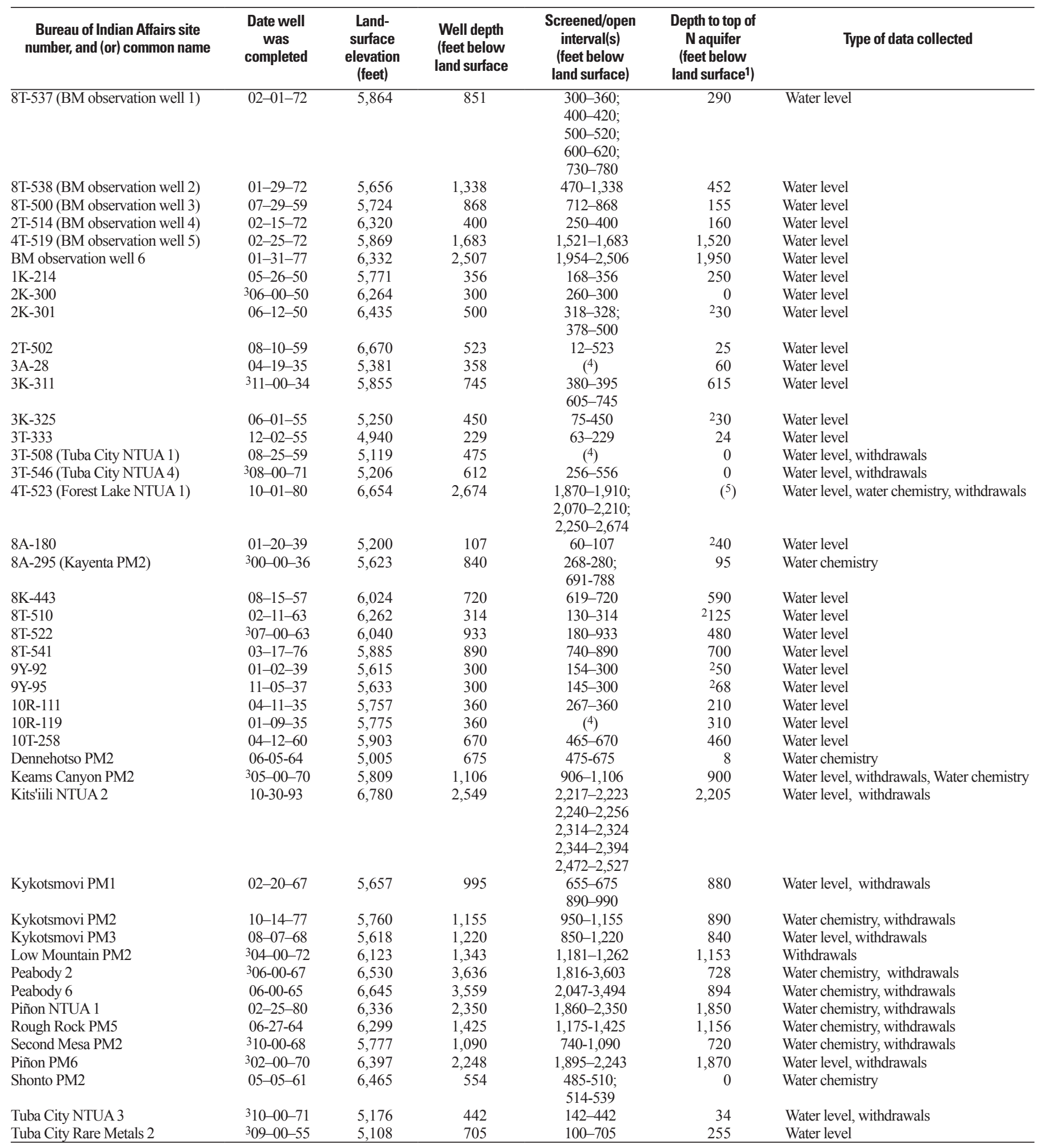

${ }^{1}$ Depth to top of N aquifer from Eychaner (1983) and Brown and Eychaner (1988).

${ }^{2}$ All material between land surface and top of the $\mathrm{N}$ aquifer is unconsolidated-soil, alluvium, or dune sand.

${ }^{3} 00$, indicates day is unknown.

${ }^{4}$ Screened and (or) open intervals are unknown.

${ }^{5}$ Depth to top of $\mathrm{N}$ aquifer was not estimated 
Table 9. Median changes in water levels in monitoring-program wells, 2009-10 and prestress period (prior to 1965) to 2010, N aquifer, Black Mesa area, northeastern Arizona

\begin{tabular}{llcc}
\hline Years & $\begin{array}{l}\text { Aquifer } \\
\text { conditions }\end{array}$ & $\begin{array}{c}\text { Number } \\
\text { of wells }\end{array}$ & $\begin{array}{c}\text { Median change in } \\
\text { water level (feet) }\end{array}$ \\
\hline \multirow{2}{*}{$2009-10$} & All & 34 & -0.2 \\
& Unconfined & 16 & 0.1 \\
& Confined & 18 & -0.3 \\
\multirow{2}{*}{ Prestress-2010 } & All & 34 & -13.9 \\
& Unconfined & 16 & -0.8 \\
& Confined & 18 & -38.7 \\
\hline
\end{tabular}

change was $-0.3 \mathrm{ft}$ (table 9). Water-level changes in the confined part of the aquifer ranged from $-6.6 \mathrm{ft}$ at Keams Canyon PM2 to $+5.6 \mathrm{ft}$ at Forest Lake NTUA 1 (4T-523) (table 7).

From the prestress period (before 1965) to 2010, the median water-level change in 34 wells was $-13.9 \mathrm{ft}$ (table 9). Water levels in 16 unconfined wells had a median change of $-0.8 \mathrm{ft}$. Waterlevel changes in the unconfined part of the aquifer ranged from $-43.9 \mathrm{ft}$ at Tuba City NTUA $1(3 \mathrm{~T}-508)$ to $+12.9 \mathrm{ft}$ at 9 Y-95 in Rough Rock (fig. 5 and table 7). Water levels in 18 wells in the confined part of the aquifer had a median change of $-38.7 \mathrm{ft}$ (table 9). Water-level changes in the confined part of the aquifer ranged from $-212.5 \mathrm{ft}$ at Keams Canyon PM2 to $+14.6 \mathrm{ft}$ at Howell Mesa 3K-311 (fig. 5 and table 7).

Hydrographs of groundwater levels in the network of wells observed annually show the temporal changes since the 1950s, 1960s, or 1970s (fig. 6). In most of the unconfined area, water levels have changed only slightly (generally less than $10 \mathrm{ft}$ ). Near Long House Valley, however, the water level in well 8T-510 has declined about $35 \mathrm{ft}$ (fig. 5 and table 7). Water levels have declined in most of the confined area; however, the magnitudes of declines are varied. Larger declines have occurred near the municipal pumping centers (wells Piñon PM6, Keams Canyon PM2) and near the wells for PWCC (BM6). Smaller declines occurred away from pumping centers in or near towns in the study area (wells 10T-258, 8K-443, 10R-111, 8T-522; fig. 5).

Hydrographs for the Black Mesa continuous-record observation wells show continuous water levels since the early 1970s (fig. 7). Water levels in the two wells in the unconfined areas (BM1 and BM4) have shown small seasonal or year-to-year variation since 1972 but no apparent long-term declines. Water levels (which have not been corrected for barometric pressure effects or seasonal effects) in wells BM2, BM3, and BM5 in the confined area have consistently declined since the early to mid 1960s (fig. 7). Since October 2009, water levels in BM2 have flattened. Water levels in BM6 in the confined area had consistently declined since the mid 1970s until the year 2007, when a distinct change occurred in the trend of the water level from decreasing to increasing. BM6 reached a maximum depth to water of $861.2 \mathrm{ft}$ below land surface on December 4, 2006, and recovered to a water level of $852.1 \mathrm{ft}$ below land surface on July 1, 2010, about 9 feet of total recovery to date.

\section{Spring Discharge from the N Aquifer}

The effect of withdrawals from the $\mathrm{N}$ aquifer on the water quality and discharge of springs around Black Mesa is a concern of the cooperators of this program. Groundwater in the $\mathrm{N}$ aquifer discharges from many springs around the margins of Black Mesa, and changes to the discharge from those springs could indicate effects of withdrawals from the $\mathrm{N}$ aquifer. In 2010, Moenkopi School Spring, Burro Spring, Pasture Canyon Spring, and Unnamed Spring near Dennehotso were measured for discharge.

Moenkopi School Spring is in the western part of the Black Mesa area and is also called Susunova Spring by the Hopi Tribe (fig. 8). Discharge from Moenkopi School Spring was measured in June 2010 by the volumetric method and compared to discharge data from previous years to determine changes over time (fig. 9). The trend for discharge measurements at this spring is not corrected for seasonal variability, but discharge measurements are made annually at the same time or as close to the same time of year. In 2010, the measured discharge was $7.4 \mathrm{gal} / \mathrm{min}$ from Moenkopi School Spring (table 10). From 2009 to 2010, discharge decreased by 7.5 percent; for the period of record, discharge measurements have a significant $(\mathrm{p}<0.05)$ decreasing trend, and linear regression analysis indicates that spring discharge decreases an average of about $0.3 \mathrm{gal} / \mathrm{yr}$ (fig. 9 and table 10).

Burro Spring is in the southwestern part of the study area and discharges from the Navajo Sandstone and alluvium (fig. 8). Burro Spring discharges from the aquifer through a metal pipe and into a cement trough for livestock. The 2010 discharge measurement and water-quality sampling point was from the end of the metal pipe before the livestock trough. Discharge at Burro Spring has fluctuated since 1989 between 0.2 and $0.4 \mathrm{gal} / \mathrm{min}$, but there is no significant $(\mathrm{p}<0.05)$ trend from linear regression and Kendall's tau analyses (fig. 9). In 2010 the measured discharge was $0.3 \mathrm{gal} / \mathrm{min}$, the same measured discharge as the previous year (fig. 9 and table 10).

A third spring measured in 2010 was Pasture Canyon Spring. Pasture Canyon Spring is in the western part of the study area and discharges from the Navajo Sandstone and alluvium (fig. 8). Discharge of Pasture Canyon Spring is measured at two locations. The first location is where the spring issues from the Navajo Sandstone, which is also the water-quality sampling point, and the second location is further down-canyon at the USGS gaging station. The USGS gaging station at Pasture Canyon measures the discharge from Pasture Canyon Spring and the additional discharge from seeps along Pasture Canyon. Discharge was measured at Pasture Canyon Spring in June 2010 by the volumetric method; when compared to discharge in previous years, a decreasing trend $(p<0.05)$ is evident from both linear regression and Kendall's tau analyses, a decrease in discharge of about $0.5 \mathrm{gal} / \mathrm{yr}$ (fig. 9 and table 10). The trend in discharge data measured at this spring, however, is not corrected for seasonal variability, but discharge measurements are made annually at the same time or as close to the same time of year. In 2010 the measured discharge was $34.3 \mathrm{gal} / \mathrm{min}$, a 10-percent increase from 2009 (table 10). 
The fourth spring measured in 2010 was Unnamed Spring near Dennehotso (fig. 8). This spring is the only spring in the northeastern part of the study area, and it discharges from the Navajo Sandstone. Discharge measurements at Unnamed Spring near Dennehotso are made by using a flume. Discharge had not been measured at Unnamed Spring near Dennehotso since 2005, however, the measurement made in 2010 shows that there has been a substantial decrease in flow since the last measurement in 2005. In 2005 the discharge at the spring was $21.5 \mathrm{gal} / \mathrm{min}$, and in 2010 the measured discharge was only $9.0 \mathrm{gal} / \mathrm{min}$ (table 10). For the period of record, there is no appreciable trend in the data based on linear regression $(p>0.05)$ and Kendall's tau analyses.

\section{Surface-Water Discharge, 2009 Water Year}

Continuous surface-water discharge data have been collected at selected streams since the monitoring program began in 1971 . Surface-water discharge in the study area generally originates as groundwater that discharges to streams and as surface runoff from rainfall or snowmelt. Groundwater discharges to some stream reaches at a fairly constant rate throughout the year; however, the
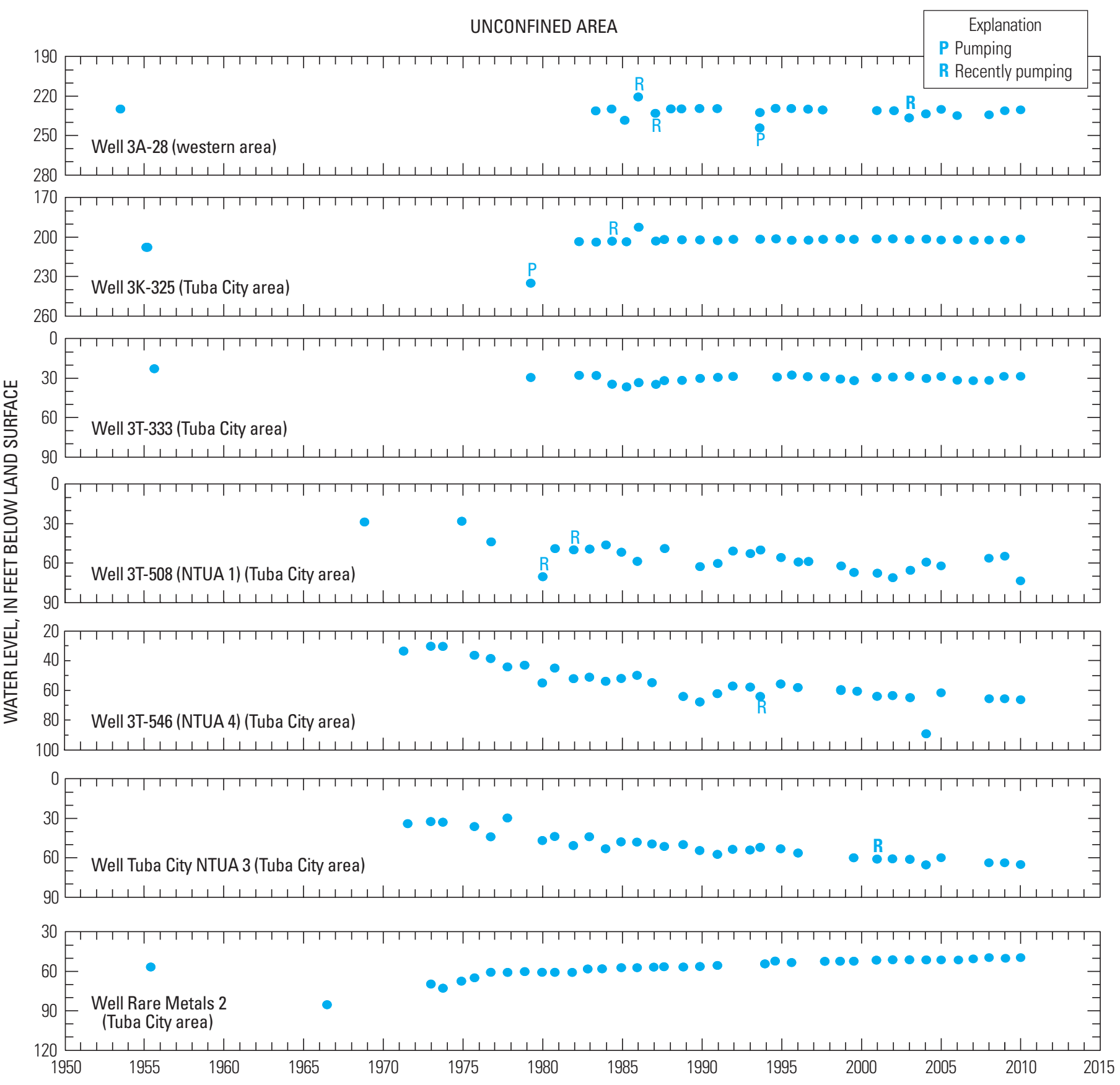

Figure 6. Water-level changes in N aquifer wells from the prestress period (prior to 1965) to 2010, Black Mesa area, northeastern Arizona. 
amount of groundwater discharge that results in surface flow is affected by seasonal fluctuations in evapotranspiration (Thomas, 2002a). In contrast, the amount of rainfall or snowmelt runoff varies widely throughout the year. In the winter and spring, the amount and timing of snowmelt runoff are a result of the temporal variation in snow accumulation, air temperatures, and rate of snowmelt. Although rainfall can occur throughout the year, most rainfall runoff occurs during the summer months. The amount and timing of rainfall runoff depend on the intensity and duration of thunderstorms during the summer and cyclonic storms during the fall, winter, and spring.
In 2009, discharge data were collected at four continuousrecording streamflow-gaging stations (tables 11-14). Data collection at these stations began in July 1976 (Moenkopi Wash at Moenkopi, 09401260), June 1993 (Dinnebito Wash near Sand Springs, 09401110), April 1994 (Polacca Wash near Second Mesa, 09400568), and August 2004 (Pasture Canyon Springs, near Tuba City, 09401265; fig. 10A; table 15). The annual average discharges at the four streamflow-gaging stations vary during the periods of record (fig. 10A), and there are no significant trends in annual average discharge for Moenkopi Wash, Polacca Wash, Dinnebito Wash, and Pasture Canyon Springs.

UNCONFINED AREA

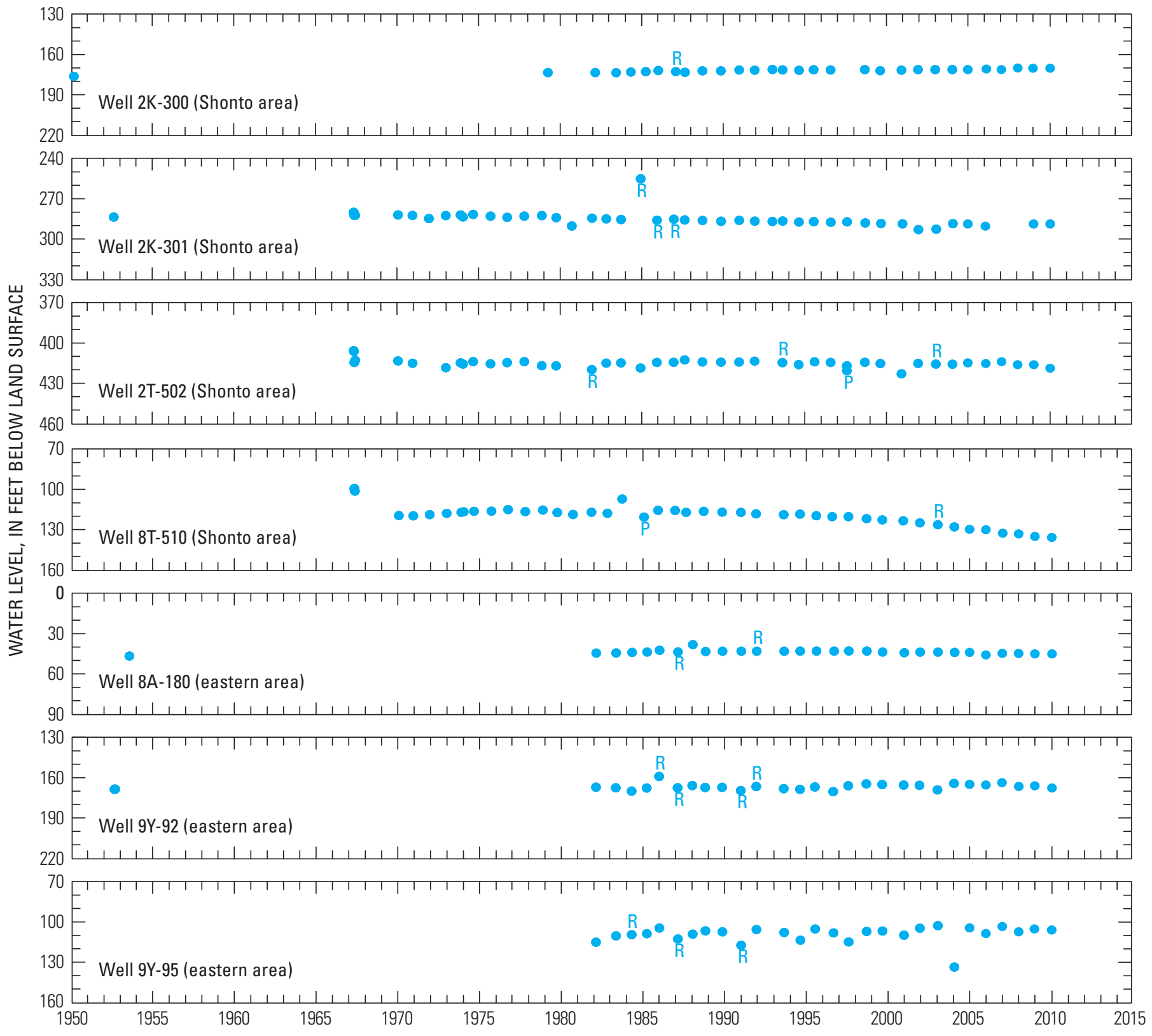

Figure 6. Water-level changes in N aquifer wells from the prestress period (prior to 1965) to 2010, Black Mesa area, northeastern Arizona. - Continued 
CONFINED AREA
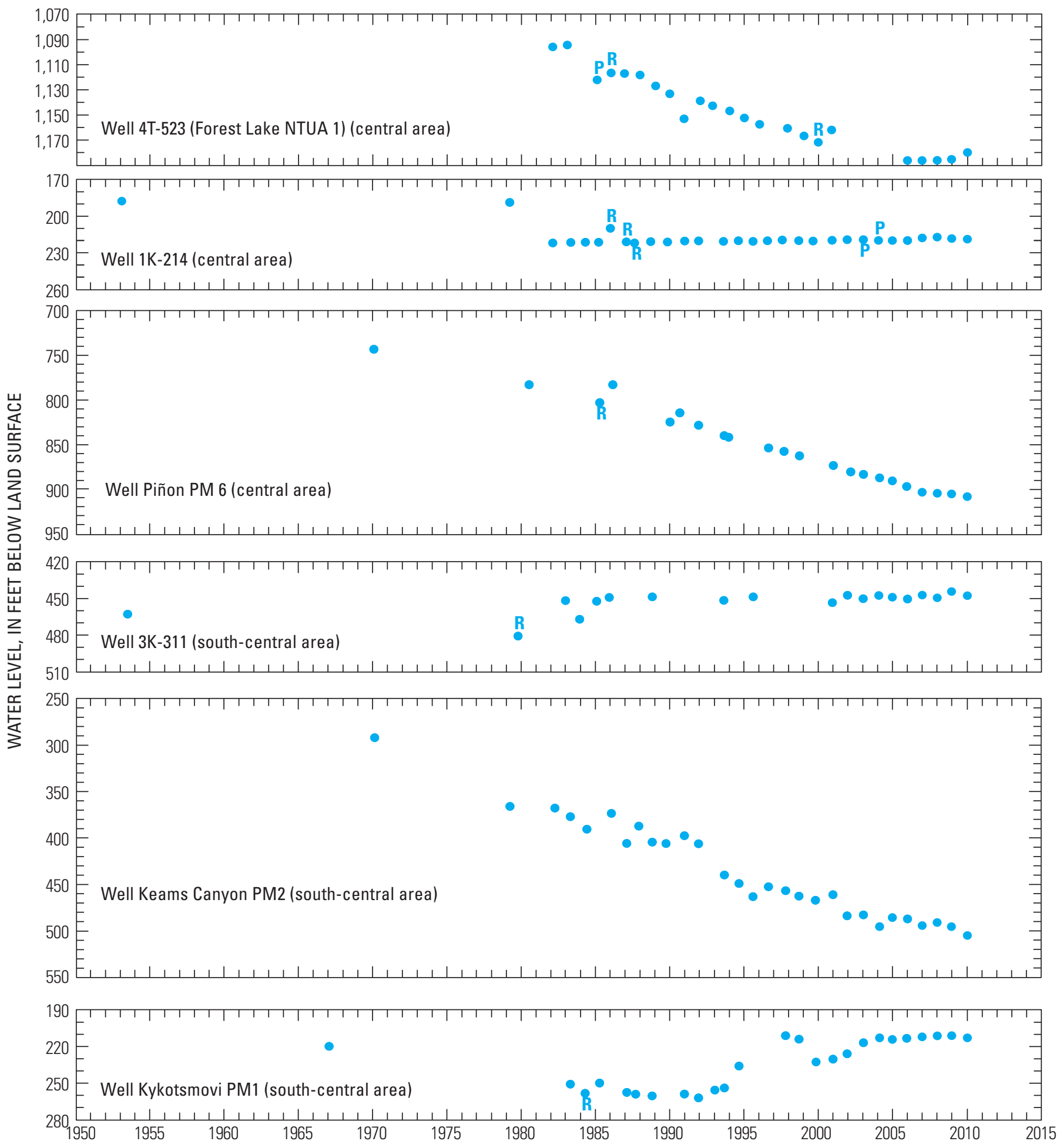

Figure 6. Water-level changes in N aquifer wells from the prestress period (prior to 1965) to 2010, Black Mesa area, northeastern Arizona. - Continued 
CONFINED AREA

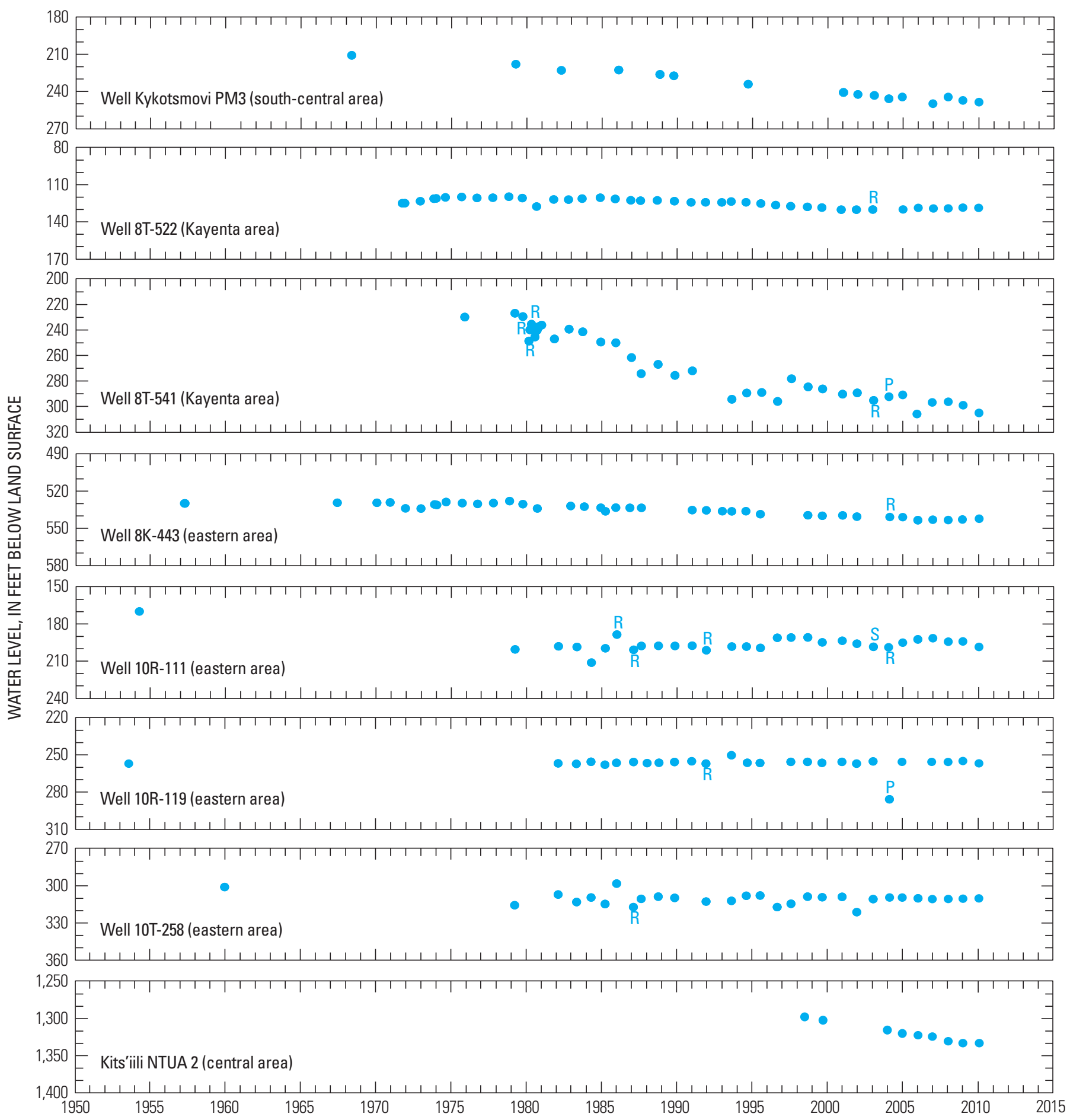

Figure 6. Water-level changes in $\mathrm{N}$ aquifer wells from the prestress period (prior to 1965) to 2010, Black Mesa area, northeastern Arizona. - Continued 


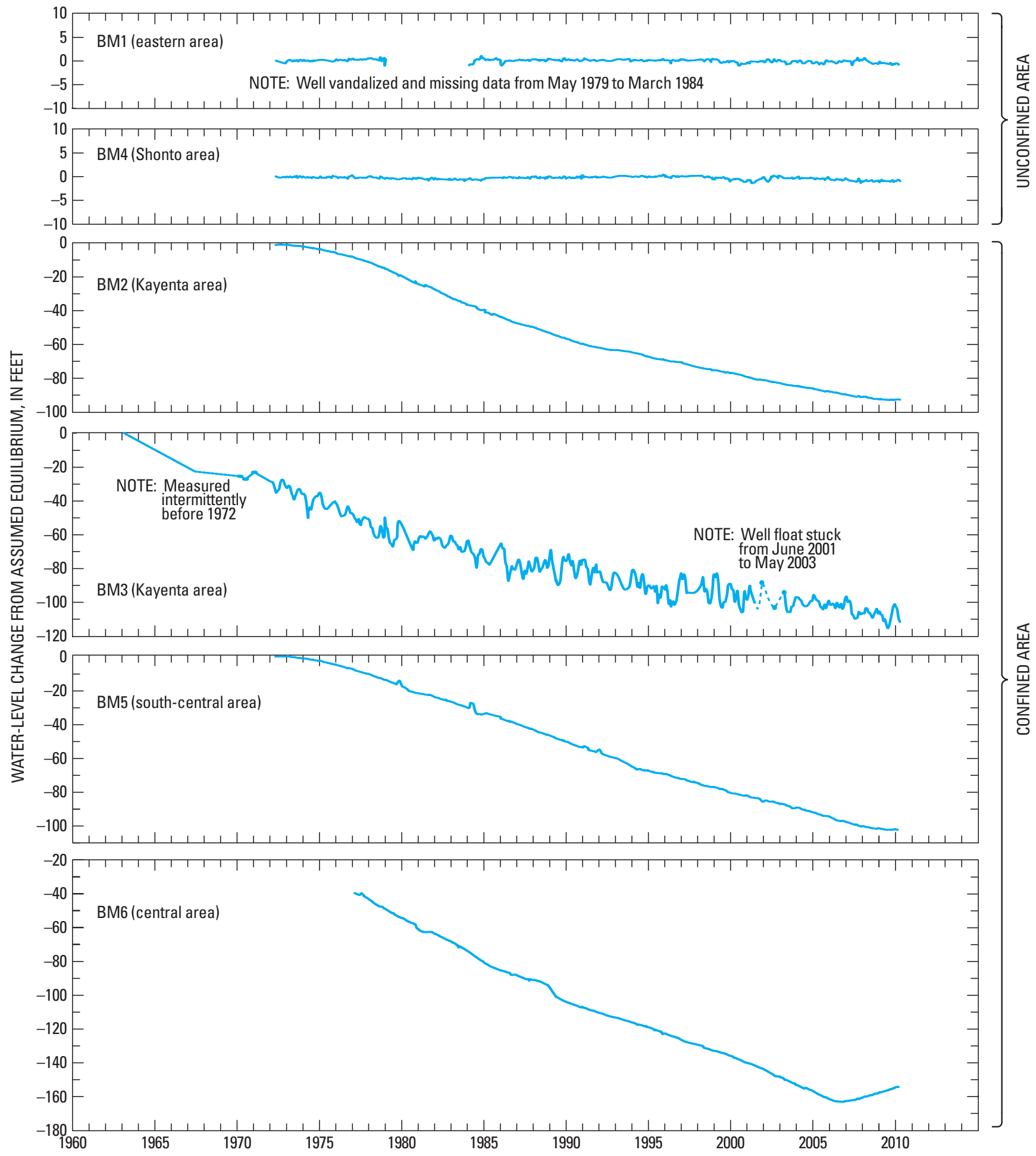

Figure 7. Observed water-level changes in continuous-record observation wells, BM1-BM6, 1963-2010, N aquifer, Black Mesa area, northeastern Arizona. 


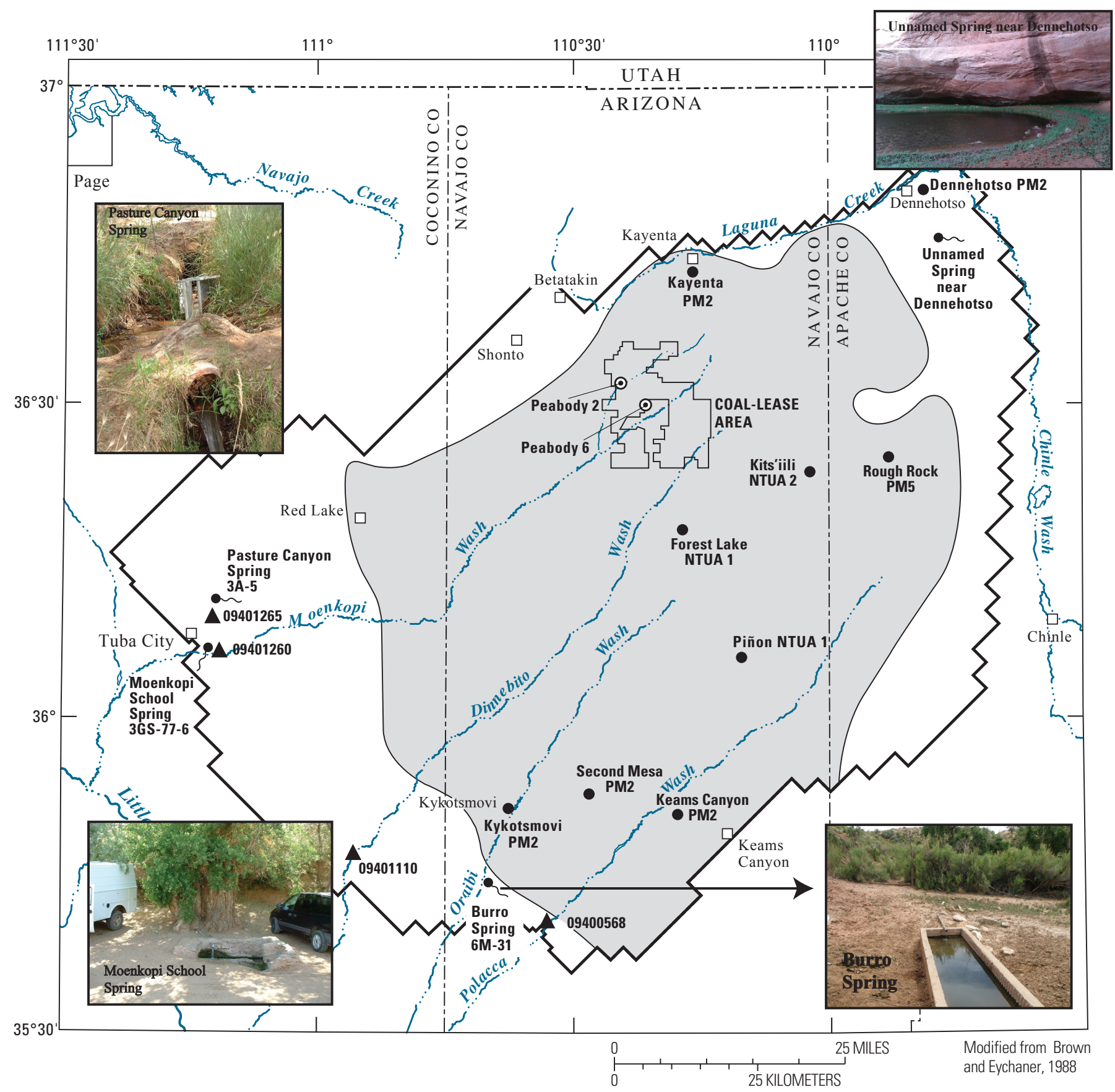

EXPLANATION

CONFINED AND UNCONFINED CONDITIONS

IN THE N AQUIFER WITHIN MODEL BOUNDARY

\section{Confined}

Unconfined

APPROXIMATE BOUNDARY BETWEEN CONFINED AND UNCONFINED CONDITIONS From Brown and Eychaner (1988)

- BOUNDARY OF MATHEMATICAL MODELFrom Brown and Eychaner (1988)

\begin{tabular}{|c|c|}
\hline $\begin{array}{c}\stackrel{\bullet}{\text { Kykotsmovi }} \\
\text { PM2 }\end{array}$ & $\begin{array}{l}\text { MUNICIPAL WELL FROM WHICH } \\
\text { WATER-CHEMISTRY SAMPLE } \\
\text { WAS COLLECTED-Kykotsmovi } \\
\text { PM2 is well name }\end{array}$ \\
\hline $\begin{array}{c}\odot \\
\text { Peabody } 2\end{array}$ & $\begin{array}{l}\text { INDUSTIAL WELL FROM WHICH } \\
\text { WATER-CHEMISTRY SAMPLE WAS } \\
\text { COLLECTED-Peabody } 2 \text { is a well } \\
\text { number }\end{array}$ \\
\hline
\end{tabular}

〜 SPRING AT WHICH DISCHARGE WAS Moenkopi MEASURED AND

School WATER-CHEMISTRY SAMPLE WAS

Spring COLLECTED-Number is spring

3GS-77-6 identification

A STREAMFLOW-GAGING STATION 09401260 OPERATED BY THE U.S. GEOLOGICAL SURVEY — Number is station identification

Figure 8. Surface-water and water-chemistry data-collection sites, N aquifer, Black Mesa area, northeastern Arizona, 2009-10. 
A. Discharge data for Moenkopi School Spring, 1987-2010.

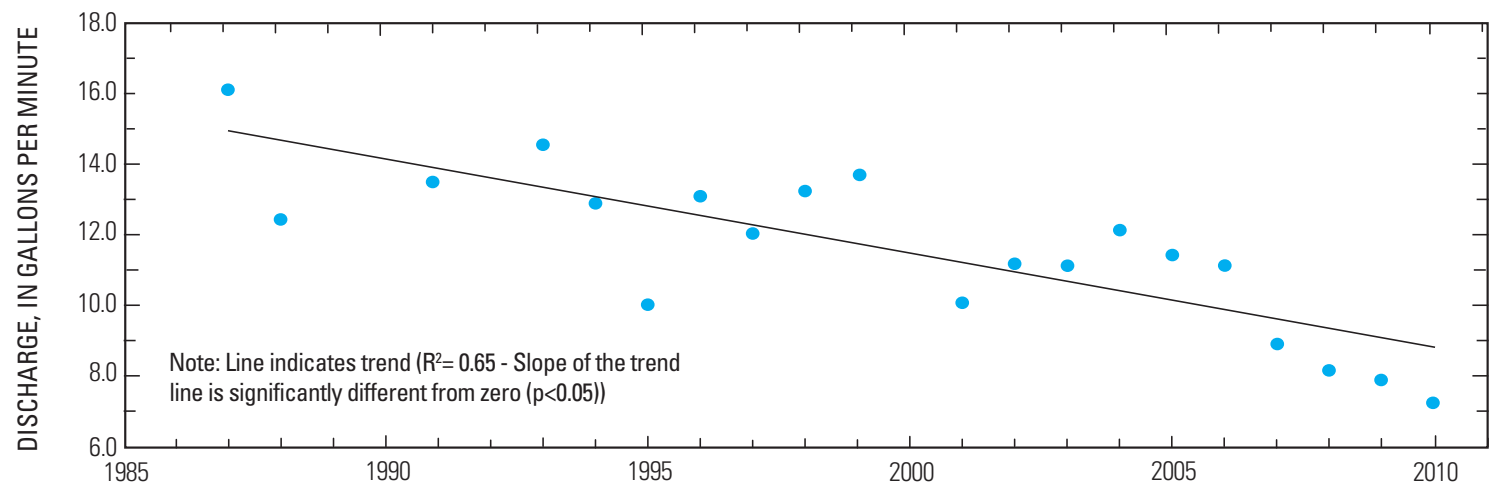

B. Discharge data for Burro Spring 1989-2010.

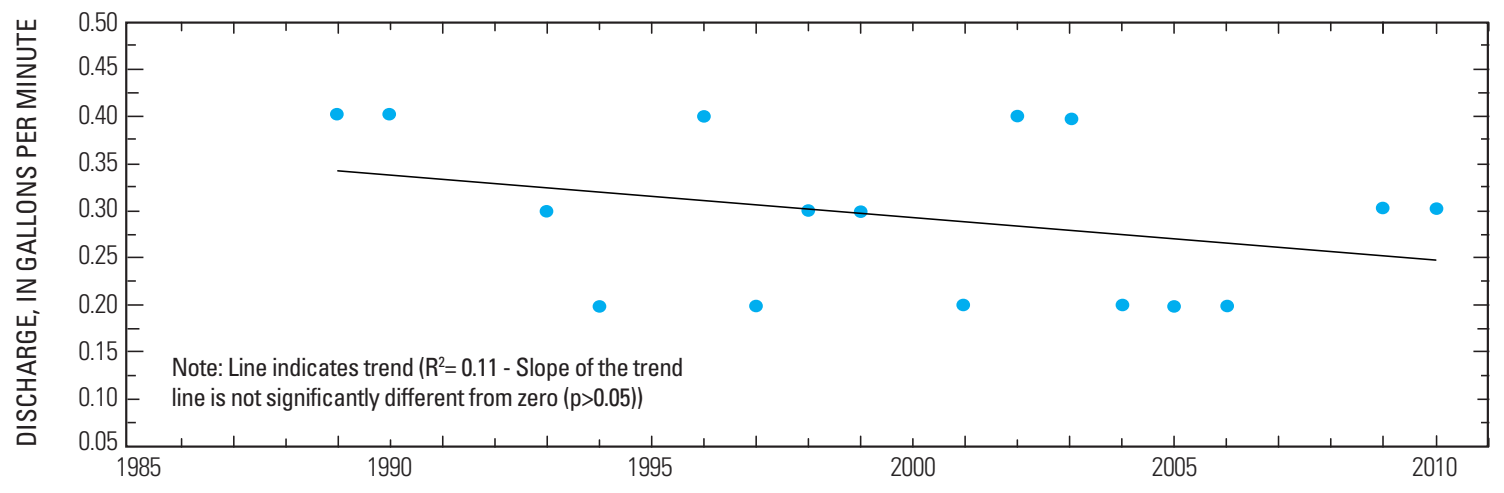

C. Discharge data for Pasture Canyon Spring, 1987-2010.

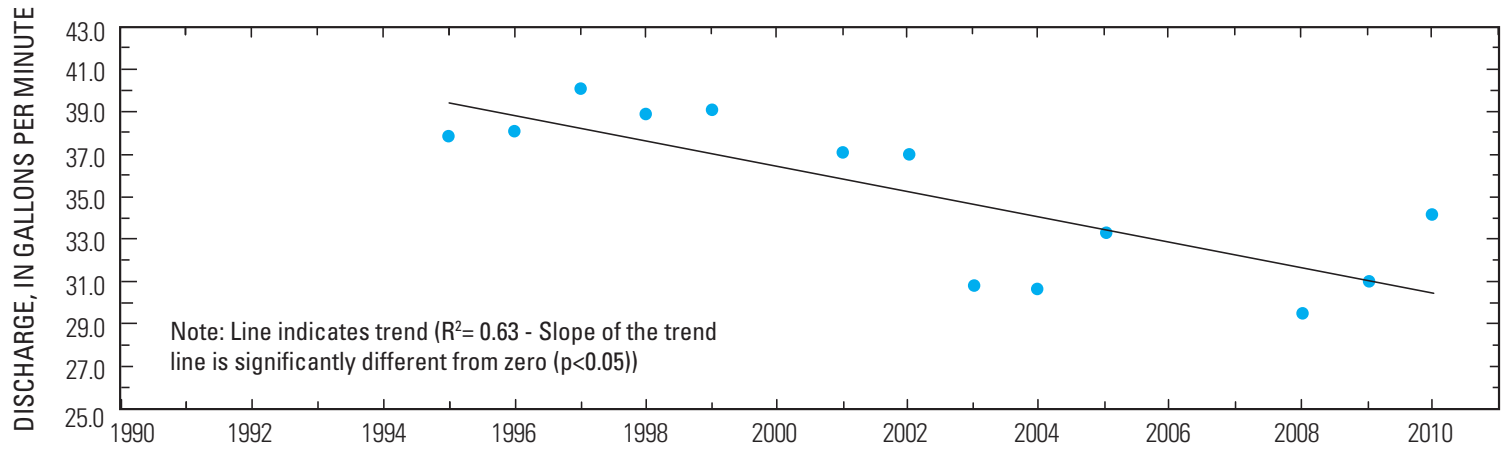

D. Discharge data for Unnamed Spring near Dennehotso, 1992-2010.

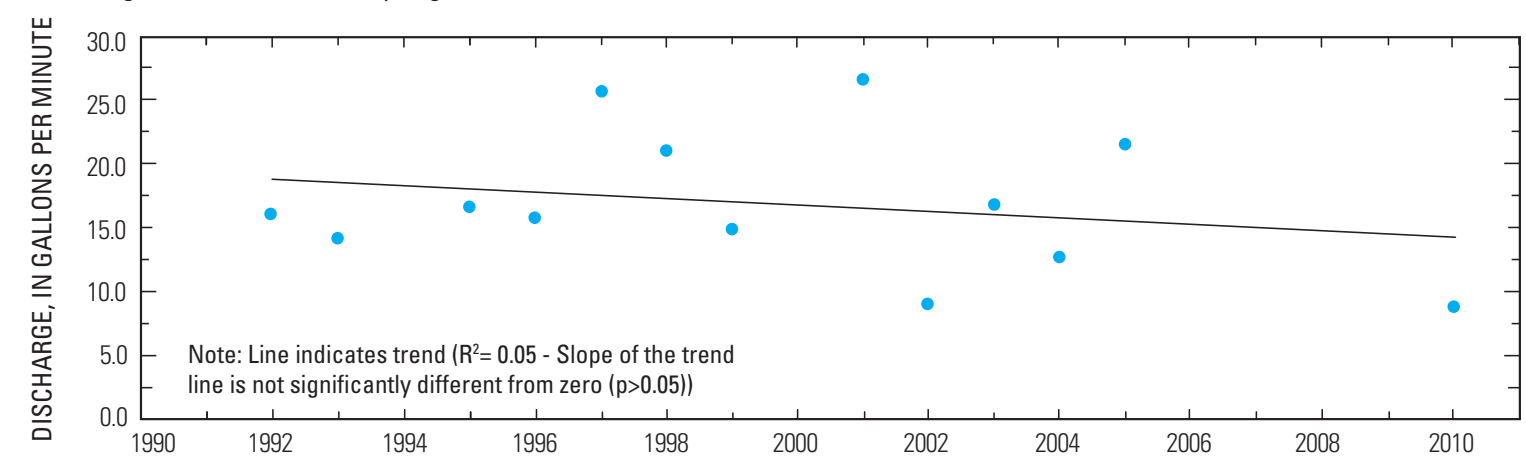

Figure 9. Discharge from $A$, Moenkopi School Spring, $B$, Burro Spring, $C$, Pasture Canyon Spring, and $D$, Unnamed Spring near Dennehotso, N aquifer, Black Mesa area, northeastern Arizona, 1987-2010. Data from 1952 measurement at Moenkopi School Spring are not shown becuse measurement was from a different measuring location. Data from 1988 to 1993 measurements at Pasture Canyon Spring are not shown beause they were from a different measuring location. Trend lines were generated by using method of least squares. 
Table 10. Discharge measurements from Moenkopi School Spring, Burro Spring, Pasture Canyon Spring, and Unnamed spring near Dennehotso in the Black Mesa area, northeastern Arizona, 1952-2010.

[Measured discharges do not represent the total discharge from the springs]

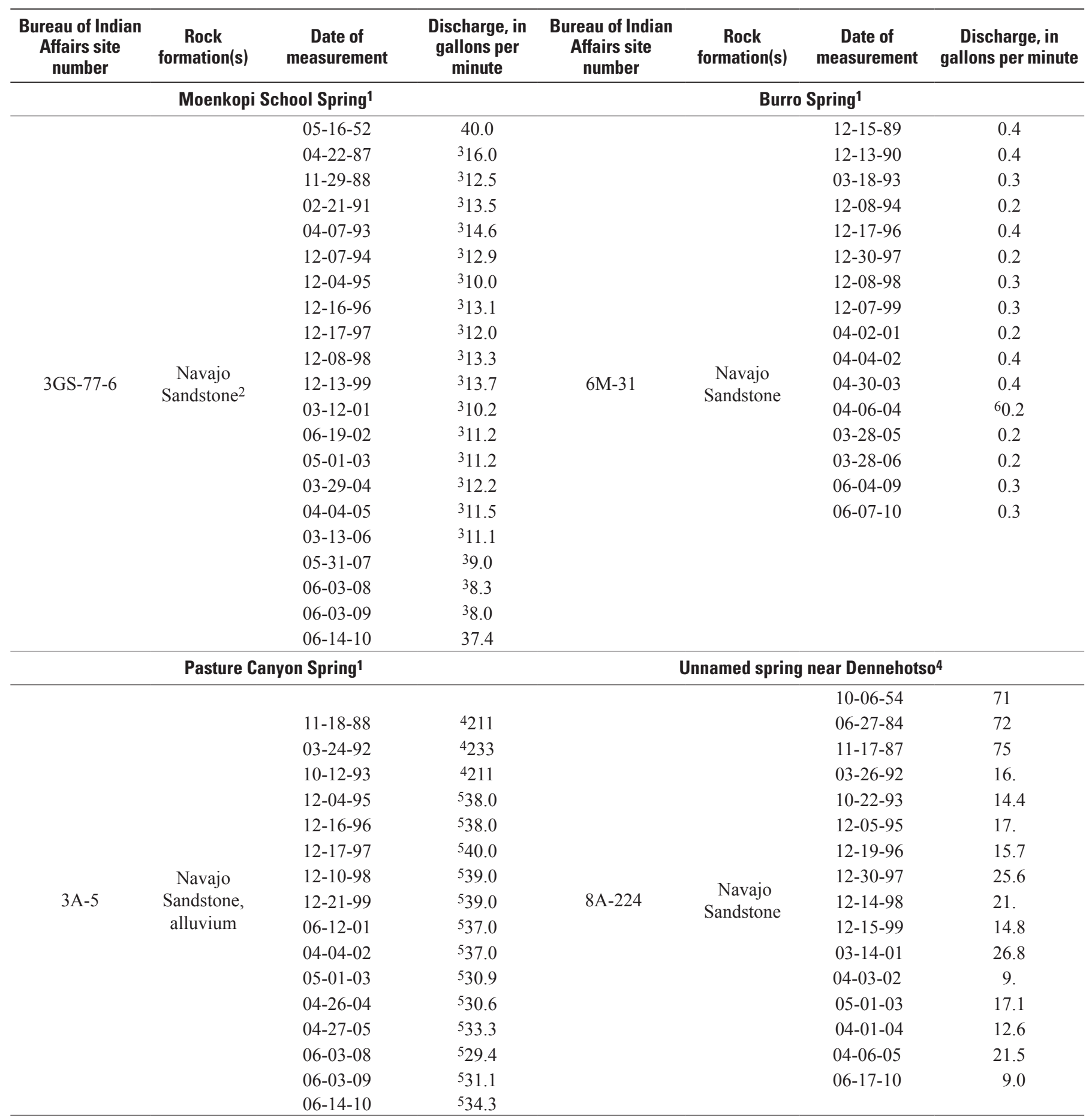

${ }^{1}$ Volumetric discharge measurement.

2Interfingering with the Kayenta Formation at this site.

${ }^{3}$ Discharge measured at water-quality sampling site and at a different point than the measurement in 1952 .

${ }^{4}$ Discharge measured in an irrigation ditch about 0.25 mile below water-quality sampling point.

${ }^{5}$ Discharge measured at water-quality sampling point about 20 feet below upper spring on west side of canyon.

${ }^{6}$ Discharge is approximate because the container used for the volumetric measurement was not calibrated.

${ }^{7}$ Discharge measured at a different point than later measurements. 
Table 11. Discharge data (daily mean values), Moenkopi Wash at Moenkopi, Arizona (09401260), calendar year 2009.

[e, estimated; CFSM, cubic feet per square mile; dashes indicate no data]

DISCHARGE, IN CUBIC FEET PER SECOND, CALENDAR YEAR 2009—DAILY MEAN VALUES

\begin{tabular}{|c|c|c|c|c|c|c|c|c|c|c|c|c|}
\hline DAY & JAN & FEB & MAR & APR & MAY & JUN & JUL & AUG & SEP & ОСТ & NOV & DEC \\
\hline 1 & e3.1 & $\mathrm{e} 2.6$ & 2.4 & 1.7 & 0.71 & 0.72 & 0.00 & 15 & 0.00 & 0.00 & 0.00 & 0.90 \\
\hline 2 & e3.0 & e2.6 & 2.5 & 1.7 & 0.62 & 0.71 & 0.00 & 1.4 & 0.00 & 0.00 & 0.00 & 1.6 \\
\hline 3 & e2.9 & $\mathrm{e} 2.6$ & 2.5 & 1.6 & 0.61 & 0.60 & 0.00 & 0.03 & 0.00 & 0.00 & 0.00 & 3.3 \\
\hline 4 & e2.9 & e2.7 & 2.3 & 1.8 & 0.57 & 0.43 & 0.00 & 0.00 & 0.00 & 0.00 & 0.00 & 1.0 \\
\hline 5 & e2.9 & e2.6 & 2.0 & 1.8 & 0.55 & 0.16 & 0.00 & 0.00 & 0.00 & 0.00 & 0.00 & 1.4 \\
\hline 6 & $\mathrm{e} 2.8$ & $\mathrm{e} 2.7$ & 2.0 & 1.6 & 0.48 & 0.00 & 0.00 & 0.00 & 0.00 & 0.00 & 0.00 & 5.2 \\
\hline 7 & e2.6 & 2.6 & 2.0 & 1.4 & 0.41 & 0.00 & 0.00 & 0.00 & 0.00 & 0.00 & 0.00 & e 5.5 \\
\hline 8 & e2.7 & 2.9 & 2.2 & 1.5 & 0.39 & 0.00 & 0.00 & 0.00 & 0.00 & 0.00 & 0.00 & e5.3 \\
\hline 9 & e2.6 & 3.3 & 2.2 & 1.5 & 0.27 & 0.00 & 0.00 & 0.00 & 0.00 & 0.00 & 0.00 & e5.3 \\
\hline 10 & e2.4 & 3.8 & 2.2 & 1.6 & 0.10 & 0.00 & 0.00 & 0.00 & 0.00 & 0.00 & 0.00 & e5.0 \\
\hline 11 & e2.3 & 3.2 & 2.4 & 1.7 & 0.10 & 0.00 & 0.00 & 0.00 & 0.00 & 0.00 & 0.00 & e4.9 \\
\hline 12 & e2.0 & 3.0 & 2.4 & 1.9 & 0.03 & 0.00 & 0.00 & 0.00 & 0.00 & 0.00 & 0.00 & e3.7 \\
\hline 13 & e2.3 & 3.4 & 2.7 & 1.7 & 0.00 & 0.00 & 0.00 & 0.00 & 0.00 & 0.00 & 0.00 & e2.7 \\
\hline 14 & e2.5 & 3.6 & 2.7 & 1.4 & 0.01 & 0.00 & 0.00 & 0.00 & 0.00 & 0.00 & 0.06 & e2.5 \\
\hline 15 & e2.4 & 2.9 & 2.6 & 1.4 & 0.01 & 0.00 & 0.00 & 0.00 & 0.00 & 0.00 & 0.11 & e3.1 \\
\hline 16 & e2.3 & 3.3 & 2.5 & 1.3 & 0.02 & 0.00 & 0.00 & 0.00 & 0.00 & 0.00 & 0.20 & e 3.2 \\
\hline 17 & $\mathrm{e} 2.1$ & 2.9 & 2.3 & 1.2 & 0.00 & 0.00 & 0.00 & 0.00 & 0.00 & 0.00 & 0.57 & $\mathrm{e} 1.4$ \\
\hline 18 & e2.5 & 2.7 & 2.4 & 1.3 & 0.00 & 0.00 & 0.00 & 0.00 & 0.00 & 0.00 & 1.4 & e0.89 \\
\hline 19 & e3.0 & 2.6 & 2.2 & 1.2 & 0.00 & 0.00 & 0.00 & 0.00 & 0.00 & 0.00 & 1.4 & 0.85 \\
\hline 20 & e3.3 & 2.7 & 2.0 & 1.0 & 0.00 & 0.00 & 0.00 & 0.00 & 0.00 & 0.00 & 0.91 & 0.93 \\
\hline 21 & e 3.3 & 2.9 & 1.8 & 1.1 & 0.00 & 0.00 & 0.00 & 0.00 & 0.00 & 0.00 & 2.2 & 1.6 \\
\hline 22 & 4.0 & 2.8 & 1.7 & 0.96 & 28 & 0.00 & 162 & 0.00 & 0.00 & 0.00 & 2.2 & 1.2 \\
\hline 23 & e4.1 & 2.7 & 1.8 & 0.84 & 271 & 0.00 & e65 & 0.00 & 0.00 & 0.00 & 0.51 & 1.1 \\
\hline 24 & 4.5 & 2.7 & 1.9 & 0.78 & e268 & 0.00 & $\mathrm{e} 0.00$ & 0.00 & 0.00 & 0.00 & 0.50 & 0.78 \\
\hline 25 & 4.1 & 2.6 & 1.9 & 0.77 & e48 & $\mathrm{e} 0.00$ & 0.00 & 0.00 & 0.00 & 0.00 & 0.15 & $\mathrm{e} 1.2$ \\
\hline 26 & 3.3 & 2.5 & 1.9 & 0.83 & e15 & $\mathrm{e} 0.00$ & 0.00 & 0.00 & 0.00 & 0.00 & $\mathrm{e} 0.51$ & $\mathrm{e} 2.4$ \\
\hline 27 & 2.8 & 2.5 & 2.0 & 0.86 & e6.9 & $\mathrm{e} 0.00$ & 0.00 & 0.00 & 0.00 & 0.00 & $\mathrm{e} 0.85$ & $\mathrm{e} 2.0$ \\
\hline 28 & 2.7 & 2.5 & 2.0 & 0.83 & $\mathrm{e} 1.5$ & $\mathrm{e} 0.00$ & 0.00 & 0.00 & 0.00 & 0.00 & $\mathrm{e} 1.5$ & 1.2 \\
\hline 29 & 2.6 & --- & 1.9 & 0.82 & 1.0 & $\mathrm{e} 0.00$ & 0.00 & 0.00 & 0.00 & 0.00 & 1.1 & 2.3 \\
\hline 30 & $\mathrm{e} 2.3$ & --- & 2.1 & 0.79 & 0.90 & 0.00 & 0.00 & 0.00 & 0.00 & 0.00 & 1.7 & 2.7 \\
\hline 31 & e2.5 & --- & 2.0 & --- & 0.80 & --- & 0.00 & 0.00 & --- & 0.00 & --- & e2.3 \\
\hline TOTAL & 88.8 & 79.9 & 67.5 & 38.88 & 645.98 & 2.62 & 227 & 16.43 & 0.00 & 0.00 & 15.87 & 77.45 \\
\hline MEAN & 2.86 & 2.85 & 2.18 & 1.3 & 20.8 & 0.09 & 7.32 & 0.53 & 0.00 & 0.00 & 0.53 & 2.5 \\
\hline MAX & 4.5 & 3.8 & 2.7 & 1.9 & 271 & 0.72 & 162 & 15 & 0.00 & 0.00 & 2.2 & 5.5 \\
\hline MIN & 2.0 & 2.5 & 1.7 & 0.77 & 0.00 & 0.00 & 0.00 & 0.00 & 0.00 & 0.00 & 0.00 & 0.78 \\
\hline MED & 2.7 & 2.7 & 2.2 & 1.3 & 0.48 & 0.00 & 0.00 & 0.00 & 0.00 & 0.00 & 0.13 & 2.3 \\
\hline AC-FT & 176 & 158 & 134 & 77 & 1280 & 5.2 & 450 & 33 & 0.00 & 0.00 & 31 & 154 \\
\hline CFSM & 0.00 & 0.00 & 0.00 & 0.00 & 0.01 & 0.00 & 0.00 & 0.00 & 0.00 & 0.00 & 0.00 & 0.00 \\
\hline $\begin{array}{c}\text { Calendar year } \\
2009 \\
\end{array}$ & \multicolumn{2}{|c|}{ Total 1,260.4 } & \multicolumn{2}{|c|}{ Mean 3.45} & $\operatorname{Max} 271$ & Min 0.00 & \multicolumn{2}{|c|}{ Median 0.55} & \multicolumn{2}{|c|}{ Acre-ft 2,498 } & \multicolumn{2}{|c|}{ CFSM 0.002} \\
\hline
\end{tabular}


Table 12. Discharge data (daily mean values), Dinnebito Wash near Sand Springs, Arizona (09401110), calendar year 2009. [e, estimated; CFSM, cubic feet per square mile; dashes indicate no data]

DISCHARGE, IN CUBIC FEET PER SECOND, CALENDAR YEAR 2009—DAILY MEAN VALUES

\begin{tabular}{|c|c|c|c|c|c|c|c|c|c|c|c|c|}
\hline DAY & JAN & FEB & MAR & APR & MAY & JUN & JUL & AUG & SEP & ОСТ & NOV & DEC \\
\hline 1 & 0.54 & 0.35 & 0.35 & 0.29 & 0.3 & 0.44 & 0.19 & 32 & 0.15 & 0.19 & 0.29 & 0.46 \\
\hline 2 & $\mathrm{e} 0.62$ & 0.36 & 0.35 & 0.29 & 0.33 & 0.42 & 0.21 & 4.7 & 0.15 & 0.20 & 0.30 & 0.44 \\
\hline 3 & 0.52 & 0.36 & 0.33 & 0.32 & 0.33 & 0.39 & 0.20 & 0.20 & 0.16 & 0.21 & 0.27 & 0.41 \\
\hline 4 & 0.50 & 0.37 & 0.32 & 0.3 & 0.37 & 0.37 & 0.17 & 0.15 & 0.16 & 0.20 & 0.24 & 0.35 \\
\hline 5 & 0.48 & 0.37 & 0.32 & 0.29 & 0.47 & 0.34 & 0.16 & 0.14 & 0.18 & 0.19 & 0.24 & 0.42 \\
\hline 6 & 0.48 & 0.37 & 0.32 & 0.28 & 0.47 & 0.33 & 0.14 & 0.13 & 0.20 & 0.20 & 0.25 & 0.50 \\
\hline 7 & 0.46 & 0.37 & 0.32 & 0.28 & 0.44 & 0.34 & 0.14 & 0.12 & 0.20 & 0.21 & 0.24 & 0.61 \\
\hline 8 & 0.48 & 0.40 & 0.32 & 0.27 & 0.45 & 0.35 & 0.15 & 0.13 & 0.21 & 0.21 & 0.25 & 7.6 \\
\hline 9 & 0.46 & 0.39 & 0.31 & 0.28 & 0.42 & 0.31 & 0.16 & 0.14 & 0.22 & 0.20 & 0.24 & 1.4 \\
\hline 10 & 0.44 & 0.60 & 0.33 & 0.29 & 0.43 & 0.30 & 0.15 & 0.14 & 0.25 & 0.20 & e2.1 & 0.67 \\
\hline 11 & 0.45 & 0.39 & 0.32 & 0.30 & 0.41 & 0.31 & 0.15 & 0.14 & 0.23 & 0.20 & $\mathrm{e} 0.44$ & 0.44 \\
\hline 12 & $\mathrm{e} 0.47$ & 0.41 & 0.34 & 0.29 & 0.37 & 0.29 & 0.15 & 0.13 & 0.22 & 0.20 & $\mathrm{e} 0.39$ & 0.59 \\
\hline 13 & 0.47 & 0.41 & 0.32 & 0.28 & 0.36 & 0.27 & 0.14 & 0.14 & 0.23 & 0.21 & 0.39 & 0.69 \\
\hline 14 & 0.47 & 0.40 & 0.32 & 0.27 & 0.38 & 0.27 & 0.14 & 0.14 & 0.23 & 0.21 & 0.41 & 0.52 \\
\hline 15 & 0.52 & 0.41 & 0.31 & 0.26 & 0.43 & 0.27 & 0.14 & 0.13 & 0.23 & 0.21 & 0.35 & 0.47 \\
\hline 16 & 0.49 & 0.42 & 0.30 & 0.25 & 0.42 & 0.27 & 0.14 & 0.13 & $\mathrm{e} 1.5$ & 0.21 & 0.35 & 0.48 \\
\hline 17 & 0.50 & 0.40 & 0.30 & 0.25 & 0.39 & 0.27 & 0.13 & 0.13 & $\mathrm{e} 0.26$ & 0.22 & 0.37 & 0.45 \\
\hline 18 & 0.49 & 0.40 & 0.30 & 0.26 & 0.42 & 0.27 & 0.13 & 0.13 & $\mathrm{e} 0.22$ & 0.24 & 0.38 & 0.48 \\
\hline 19 & 0.52 & 0.41 & 0.31 & 0.26 & 0.36 & 0.26 & 0.12 & 0.13 & 0.21 & 0.24 & 0.37 & 0.45 \\
\hline 20 & 0.52 & 0.41 & 0.31 & 0.25 & 0.35 & 0.28 & 0.13 & 0.13 & 0.20 & 0.24 & 0.38 & 0.46 \\
\hline 21 & 0.55 & 0.40 & 0.30 & 0.26 & 0.44 & 0.23 & 1.8 & 0.13 & $\mathrm{e} 0.23$ & 0.25 & 0.38 & 0.50 \\
\hline 22 & 0.58 & 0.39 & 0.30 & 0.26 & 26 & 0.22 & 1.2 & 0.16 & $\mathrm{e} 0.22$ & 0.25 & 0.38 & $\mathrm{e} 0.55$ \\
\hline 23 & 0.65 & 0.38 & 0.31 & 0.25 & 11 & 0.22 & 0.33 & 0.24 & $\mathrm{e} 0.19$ & 0.26 & 0.38 & $\mathrm{e} 0.59$ \\
\hline 24 & 0.65 & 0.39 & 0.31 & 0.25 & 9.4 & 0.22 & 0.14 & 0.79 & 0.19 & 0.26 & 0.35 & 0.42 \\
\hline 25 & 0.51 & 0.35 & 0.31 & 0.24 & 1.3 & 0.22 & 0.13 & 0.16 & 0.19 & 0.26 & 0.36 & 0.38 \\
\hline 26 & 0.96 & 0.34 & 0.31 & 0.25 & 0.64 & 0.25 & 0.46 & 0.16 & 0.19 & 0.26 & 0.38 & 0.39 \\
\hline 27 & 0.50 & 0.34 & 0.30 & 0.26 & 0.54 & 0.22 & 0.69 & 0.15 & 0.19 & 0.31 & 0.41 & 0.38 \\
\hline 28 & 0.35 & 0.34 & 0.31 & 0.26 & 0.41 & 0.21 & 0.69 & 0.15 & 0.19 & 0.48 & 0.46 & 0.40 \\
\hline 29 & 0.35 & --- & 0.30 & 0.28 & 1.0 & 0.23 & 0.14 & 0.15 & 0.18 & 0.29 & 0.52 & 0.50 \\
\hline 30 & 0.35 & --- & 0.31 & 0.29 & 0.76 & 0.23 & $\mathrm{e} 0.22$ & 0.15 & 0.18 & 0.28 & 0.48 & 0.50 \\
\hline 31 & 0.36 & --- & 0.30 & --- & 0.48 & --- & $\mathrm{e} 0.32$ & 0.15 & --- & 0.29 & --- & 0.54 \\
\hline TOTAL & 15.69 & 10.93 & 9.76 & 8.16 & 59.87 & 8.6 & 9.16 & 41.57 & 7.36 & 7.38 & 12.35 & 23.04 \\
\hline MEAN & 0.51 & 0.39 & 0.31 & 0.27 & 1.93 & 0.29 & 0.3 & 1.34 & 0.25 & 0.24 & 0.41 & 0.74 \\
\hline MAX & 0.96 & 0.60 & 0.35 & 0.32 & 26 & 0.44 & 1.8 & 32 & 1.5 & 0.48 & 2.1 & 7.6 \\
\hline MIN & 0.35 & 0.34 & 0.30 & 0.24 & 0.30 & 0.21 & 0.12 & 0.12 & 0.15 & 0.19 & 0.24 & 0.35 \\
\hline MED & 0.49 & 0.39 & 0.31 & 0.27 & 0.43 & 0.27 & 0.15 & 0.14 & 0.20 & 0.21 & 0.38 & 0.48 \\
\hline AC-FT & 31 & 22 & 19 & 16 & 119 & 17 & 18 & 82 & 15 & 15 & 24 & 46 \\
\hline CFSM & 0.00 & 0.00 & 0.00 & 0.00 & 0.00 & 0.00 & 0.00 & 0.00 & 0.00 & 0.00 & 0.00 & 0.00 \\
\hline $\begin{array}{c}\text { Calendar year } \\
2009\end{array}$ & \multicolumn{2}{|c|}{ Total 213.9} & \multicolumn{2}{|c|}{ Mean 0.58} & Max 32 & $\operatorname{Min} 0.12$ & \multicolumn{2}{|c|}{ Median 0.31} & \multicolumn{2}{|c|}{ Acre-ft 424} & \multicolumn{2}{|c|}{ CFSM 0.001} \\
\hline
\end{tabular}


Table 13. Discharge data (daily mean values), Polacca Wash near Second Mesa, Arizona (09400568), calendar year 2009.

[e, estimated; CFSM, cubic feet per square mile; dashes indicate no data]

DISCHARGE, IN CUBIC FEET PER SECOND, CALENDAR YEAR 2009_DAILY MEAN VALUES

\begin{tabular}{|c|c|c|c|c|c|c|c|c|c|c|c|c|}
\hline DAY & JAN & FEB & MAR & APR & MAY & JUN & JUL & AUG & SEP & ОСТ & NOV & DEC \\
\hline 1 & 0.29 & $\mathrm{e} 0.36$ & $\mathrm{e} 0.26$ & $\mathrm{e} 0.24$ & $\mathrm{e} 0.21$ & 0.15 & $\mathrm{e} 0.09$ & 0.01 & 0.02 & 0.05 & 0.06 & 0.10 \\
\hline 2 & 0.28 & $\mathrm{e} 0.36$ & 0.22 & 0.25 & $\mathrm{e} 0.21$ & 0.16 & 0.07 & 0.01 & 0.03 & 0.05 & 0.06 & 0.11 \\
\hline 3 & 0.30 & $\mathrm{e} 0.38$ & 0.28 & 0.27 & $\mathrm{e} 0.22$ & 0.17 & $\mathrm{e} 0.08$ & 0.01 & 0.04 & 0.05 & 0.06 & 0.13 \\
\hline 4 & $\mathrm{e} 0.33$ & $\mathrm{e} 0.37$ & 0.32 & 0.26 & $\mathrm{e} 0.20$ & $\mathrm{e} 0.17$ & $\mathrm{e} 0.09$ & 0.01 & 0.04 & 0.06 & 0.07 & e 0.16 \\
\hline 5 & $\mathrm{e} 0.35$ & $\mathrm{e} 0.37$ & 0.27 & 0.22 & $\mathrm{e} 0.20$ & 0.16 & $\mathrm{e} 0.09$ & 0.01 & 0.04 & 0.05 & 0.07 & e0.37 \\
\hline 6 & $\mathrm{e} 0.35$ & $\mathrm{e} 0.35$ & 0.24 & 0.23 & e0.19 & $\mathrm{e} 0.15$ & $\mathrm{e} 0.08$ & 0.01 & 0.05 & 0.05 & 0.06 & e0.39 \\
\hline 7 & 0.32 & 0.33 & $\mathrm{e} 0.25$ & 0.23 & 0.17 & $\mathrm{e} 0.15$ & $\mathrm{e} 0.08$ & 0.01 & 0.05 & 0.06 & 0.06 & $\mathrm{e} 0.29$ \\
\hline 8 & 0.29 & 0.30 & $\mathrm{e} 0.26$ & 0.25 & 0.16 & $\mathrm{e} 0.14$ & $\mathrm{e} 0.07$ & 0.00 & 0.05 & 0.06 & 0.07 & $\mathrm{e} 0.22$ \\
\hline 9 & 0.33 & $\mathrm{e} 0.33$ & $\mathrm{e} 0.23$ & 0.22 & 0.16 & $\mathrm{e} 0.12$ & $\mathrm{e} 0.06$ & 0.01 & 0.05 & 0.08 & 0.07 & $\mathrm{e} 0.22$ \\
\hline 10 & 0.39 & $\mathrm{e} 0.26$ & $\mathrm{e} 0.21$ & 0.21 & 0.15 & 0.13 & 0.06 & 0.02 & 0.05 & 0.09 & 0.07 & $\mathrm{e} 0.27$ \\
\hline 11 & 0.42 & $\mathrm{e} 0.24$ & $\mathrm{e} 0.21$ & 0.24 & 0.15 & 0.13 & 0.06 & 0.01 & 0.05 & 0.05 & 0.07 & $\mathrm{e} 0.26$ \\
\hline 12 & 0.41 & $\mathrm{e} 0.24$ & $\mathrm{e} 0.22$ & $\mathrm{e} 0.23$ & 0.13 & $\mathrm{e} 0.12$ & 0.05 & 0.01 & 0.04 & 0.05 & 0.08 & e0.16 \\
\hline 13 & $\mathrm{e} 0.37$ & $\mathrm{e} 0.24$ & $\mathrm{e} 0.22$ & $\mathrm{e} 0.21$ & 0.16 & $\mathrm{e} 0.12$ & 0.05 & 0.02 & 0.05 & 0.05 & 0.08 & $\mathrm{e} 0.14$ \\
\hline 14 & $\mathrm{e} 0.35$ & $\mathrm{e} 0.25$ & $\mathrm{e} 0.21$ & $\mathrm{e} 0.20$ & 0.18 & $\mathrm{e} 0.12$ & 0.04 & $\mathrm{e} 0.02$ & 0.05 & 0.05 & 0.08 & 0.13 \\
\hline 15 & $\mathrm{e} 0.35$ & $\mathrm{e} 0.25$ & $\mathrm{e} 0.21$ & $\mathrm{e} 0.21$ & 0.17 & $\mathrm{e} 0.11$ & 0.04 & $\mathrm{e} 0.02$ & 0.05 & 0.05 & 0.08 & 0.16 \\
\hline 16 & $\mathrm{e} 0.31$ & $\mathrm{e} 0.27$ & $\mathrm{e} 0.24$ & $\mathrm{e} 0.21$ & 0.16 & $\mathrm{e} 0.11$ & 0.04 & $\mathrm{e} 0.02$ & 0.05 & 0.06 & 0.08 & e0.17 \\
\hline 17 & $\mathrm{e} 0.30$ & 0.27 & 0.25 & $\mathrm{e} 0.23$ & 0.16 & 0.11 & 0.04 & $\mathrm{e} 0.02$ & 0.05 & 0.06 & 0.08 & 0.16 \\
\hline 18 & $\mathrm{e} 0.30$ & 0.26 & 0.31 & $\mathrm{e} 0.25$ & 0.18 & 0.11 & 0.04 & $\mathrm{e} 0.02$ & 0.05 & 0.06 & 0.08 & 0.14 \\
\hline 19 & $\mathrm{e} 0.28$ & 0.27 & 0.33 & $\mathrm{e} 0.28$ & 0.17 & 0.09 & 0.04 & 0.02 & 0.05 & 0.07 & 0.08 & 0.16 \\
\hline 20 & $\mathrm{e} 0.28$ & 0.29 & 0.32 & $\mathrm{e} 0.25$ & 0.15 & 0.12 & 0.04 & 0.02 & 0.05 & 0.07 & 0.09 & 0.18 \\
\hline 21 & $\mathrm{e} 0.30$ & $\mathrm{e} 0.28$ & 0.28 & $\mathrm{e} 0.22$ & 0.11 & 0.11 & 0.03 & 0.02 & 0.04 & 0.07 & 0.09 & $\mathrm{e} 0.14$ \\
\hline 22 & 0.29 & $\mathrm{e} 0.28$ & 0.25 & $\mathrm{e} 0.19$ & 44 & 0.09 & 0.03 & 0.02 & 0.04 & 0.07 & 0.08 & 0.10 \\
\hline 23 & 0.31 & $\mathrm{e} 0.26$ & 0.26 & 0.23 & 8.3 & 0.09 & 0.02 & 0.04 & 0.05 & 0.07 & 0.09 & 0.19 \\
\hline 24 & 0.34 & $\mathrm{e} 0.24$ & 0.27 & 0.23 & 47 & 0.10 & 0.02 & 0.04 & 0.05 & 0.07 & 0.11 & 0.17 \\
\hline 25 & 0.35 & 0.24 & $\mathrm{e} 0.29$ & 0.19 & e12 & 0.09 & 0.02 & 0.03 & 0.05 & 0.07 & 0.13 & $\mathrm{e} 0.26$ \\
\hline 26 & 0.37 & $\mathrm{e} 0.26$ & $\mathrm{e} 0.33$ & $\mathrm{e} 0.20$ & $\mathrm{e} 0.74$ & 0.09 & 0.01 & 0.03 & 0.05 & 0.07 & 0.14 & $\mathrm{e} 0.36$ \\
\hline 27 & 0.41 & $\mathrm{e} 0.25$ & $\mathrm{e} 0.31$ & $\mathrm{e} 0.19$ & $\mathrm{e} 0.26$ & 0.10 & 0.02 & 0.03 & 0.05 & 0.08 & 0.11 & $\mathrm{e} 0.31$ \\
\hline 28 & $\mathrm{e} 0.37$ & $\mathrm{e} 0.25$ & $\mathrm{e} 0.27$ & $\mathrm{e} 0.20$ & $\mathrm{e} 0.21$ & $\mathrm{e} 0.10$ & $\mathrm{e} 0.02$ & 0.02 & 0.05 & 0.08 & 0.08 & $\mathrm{e} 0.26$ \\
\hline 29 & $\mathrm{e} 0.38$ & --- & $\mathrm{e} 0.24$ & $\mathrm{e} 0.19$ & $\mathrm{e} 0.18$ & 0.13 & $\mathrm{e} 0.02$ & 0.03 & 0.05 & 0.07 & 0.08 & $\mathrm{e} 0.21$ \\
\hline 30 & $\mathrm{e} 0.40$ & --- & $\mathrm{e} 0.23$ & $\mathrm{e} 0.21$ & 0.37 & $\mathrm{e} 0.10$ & 0.01 & 0.02 & 0.05 & 0.07 & 0.08 & $\mathrm{e} 0.23$ \\
\hline 31 & $\mathrm{e} 0.39$ & --- & $\mathrm{e} 0.24$ & --- & 0.18 & --- & 0.01 & 0.02 & --- & 0.07 & --- & $\mathrm{e} 0.25$ \\
\hline TOTAL & 10.51 & 8.05 & 8.03 & 6.74 & 116.83 & 3.64 & 1.42 & 0.58 & 1.39 & 1.96 & 2.44 & 6.4 \\
\hline MEAN & 0.34 & 0.29 & 0.26 & 0.22 & 3.77 & 0.12 & 0.05 & 0.02 & 0.05 & 0.06 & 0.08 & 0.21 \\
\hline MAX & 0.42 & 0.38 & 0.33 & 0.28 & 47 & 0.17 & 0.09 & 0.04 & 0.05 & 0.09 & 0.14 & 0.39 \\
\hline MIN & 0.28 & 0.24 & 0.21 & 0.19 & 0.11 & 0.09 & 0.01 & 0.00 & 0.02 & 0.05 & 0.06 & 0.10 \\
\hline MED & 0.34 & 0.27 & 0.25 & 0.23 & 0.18 & 0.12 & 0.04 & 0.02 & 0.05 & 0.06 & 0.08 & 0.18 \\
\hline AC-FT & 21 & 16 & 16 & 13 & 232 & 7.2 & 2.8 & 1.2 & 2.8 & 3.9 & 4.8 & 13 \\
\hline CFSM & 0.00 & 0.00 & 0.00 & 0.00 & 0.00 & 0.00 & 0.00 & 0.00 & 0.00 & 0.00 & 0.00 & 0.00 \\
\hline $\begin{array}{c}\text { Calendar year } \\
2009 \\
\end{array}$ & \multicolumn{2}{|c|}{ Total 168.00} & \multicolumn{2}{|c|}{ Mean 0.46} & Max 47 & Min 0.0 & \multicolumn{2}{|c|}{ Median 0.14} & \multicolumn{2}{|c|}{ Acre-ft 333.7} & \multicolumn{2}{|c|}{ CFSM 0.0005} \\
\hline
\end{tabular}


Table 14. Discharge data (daily mean values), Pasture Canyon Springs near Tuba City, Arizona (09401265), calendar year 2009. [e, estimated; CFSM, cubic feet per square mile; dashes indicate no data]

DISCHARGE, IN CUBIC FEET PER SECOND, CALENDAR YEAR 2009—DAILY MEAN VALUES

\begin{tabular}{|c|c|c|c|c|c|c|c|c|c|c|c|c|}
\hline DAY & JAN & FEB & MAR & APR & MAY & JUN & JUL & AUG & SEP & ОСТ & NOV & DEC \\
\hline 1 & 0.41 & 0.36 & 0.32 & 0.32 & 0.32 & 0.28 & 0.27 & 0.27 & 0.24 & 0.26 & 0.35 & 0.33 \\
\hline 2 & 0.41 & 0.36 & 0.32 & 0.29 & 0.32 & 0.27 & 0.27 & 0.25 & 0.24 & 0.25 & 0.37 & 0.32 \\
\hline 3 & 0.42 & 0.36 & 0.32 & 0.33 & 0.32 & 0.27 & $\mathrm{e} 0.40$ & 0.25 & 0.25 & 0.24 & 0.36 & 0.32 \\
\hline 4 & 0.43 & 0.35 & 0.33 & 0.34 & 0.32 & 0.28 & 0.30 & 0.25 & 0.24 & 0.26 & 0.36 & 0.32 \\
\hline 5 & 0.43 & 0.34 & 0.33 & 0.35 & 0.32 & 0.28 & 0.28 & 0.25 & 0.24 & 0.25 & 0.35 & 0.32 \\
\hline 6 & 0.43 & 0.34 & 0.34 & 0.35 & 0.32 & 0.28 & 0.28 & 0.26 & 0.24 & 0.26 & 0.34 & 0.32 \\
\hline 7 & 0.43 & 0.34 & 0.34 & 0.36 & 0.31 & 0.28 & 0.27 & 0.26 & 0.25 & 0.25 & 0.33 & 0.34 \\
\hline 8 & 0.43 & 0.40 & 0.34 & 0.35 & 0.30 & 0.28 & 0.24 & 0.26 & 0.24 & 0.26 & 0.33 & 0.43 \\
\hline 9 & 0.43 & 0.38 & 0.34 & 0.34 & 0.30 & 0.28 & 0.22 & 0.25 & 0.24 & 0.26 & 0.34 & 0.41 \\
\hline 10 & 0.43 & 0.37 & 0.34 & 0.35 & 0.30 & 0.28 & 0.23 & 0.25 & 0.25 & 0.26 & $\mathrm{e} 0.35$ & 0.41 \\
\hline 11 & 0.43 & 0.36 & 0.36 & 0.36 & 0.30 & 0.28 & 0.23 & 0.25 & 0.23 & 0.24 & 0.34 & 0.41 \\
\hline 12 & 0.42 & 0.36 & 0.34 & 0.34 & 0.30 & 0.28 & 0.22 & 0.24 & 0.26 & 0.22 & 0.34 & 0.42 \\
\hline 13 & 0.41 & 0.36 & 0.34 & 0.33 & 0.30 & 0.29 & 0.23 & 0.26 & 0.27 & 0.21 & 0.34 & 0.44 \\
\hline 14 & 0.41 & 0.36 & 0.33 & 0.32 & 0.30 & 0.30 & 0.23 & 0.27 & 0.28 & 0.23 & 0.34 & 0.37 \\
\hline 15 & 0.39 & 0.36 & 0.31 & 0.34 & 0.30 & 0.30 & 0.23 & 0.27 & 0.28 & 0.24 & 0.34 & 0.33 \\
\hline 16 & 0.38 & 0.35 & 0.31 & 0.34 & 0.30 & 0.30 & 0.24 & 0.25 & 0.29 & 0.26 & 0.34 & 0.35 \\
\hline 17 & 0.38 & 0.36 & 0.31 & 0.34 & 0.30 & 0.31 & 0.25 & 0.25 & 0.28 & 0.25 & 0.34 & 0.36 \\
\hline 18 & 0.39 & 0.36 & 0.33 & 0.33 & 0.31 & 0.29 & 0.25 & 0.26 & 0.28 & 0.23 & 0.34 & 0.36 \\
\hline 19 & 0.42 & 0.36 & 0.34 & 0.33 & 0.32 & 0.27 & 0.26 & 0.26 & 0.27 & 0.24 & 0.34 & 0.36 \\
\hline 20 & 0.43 & 0.36 & 0.34 & 0.33 & 0.26 & 0.27 & 0.27 & 0.25 & 0.26 & 0.25 & 0.36 & 0.34 \\
\hline 21 & 0.41 & 0.36 & 0.34 & 0.32 & 0.25 & 0.26 & 0.27 & 0.25 & 0.26 & 0.27 & 0.38 & 0.36 \\
\hline 22 & 0.41 & 0.35 & 0.32 & 0.32 & 0.29 & 0.25 & 0.27 & 0.26 & 0.25 & 0.28 & 0.37 & 0.39 \\
\hline 23 & 0.41 & 0.34 & 0.32 & 0.32 & 0.35 & 0.25 & 0.28 & 0.24 & 0.25 & 0.27 & 0.36 & 0.35 \\
\hline 24 & 0.41 & 0.35 & 0.32 & 0.32 & 0.31 & 0.25 & 0.26 & 0.25 & 0.26 & 0.28 & 0.36 & 0.32 \\
\hline 25 & 0.41 & 0.34 & 0.33 & 0.32 & 0.28 & 0.27 & 0.24 & 0.25 & 0.27 & 0.25 & 0.36 & 0.32 \\
\hline 26 & 0.39 & 0.32 & 0.34 & 0.32 & 0.27 & 0.27 & 0.25 & 0.25 & 0.26 & 0.24 & 0.36 & 0.32 \\
\hline 27 & 0.38 & 0.32 & 0.34 & 0.32 & 0.28 & 0.29 & 0.27 & 0.31 & 0.25 & 0.25 & 0.35 & 0.33 \\
\hline 28 & 0.38 & 0.32 & 0.33 & 0.32 & 0.29 & 0.29 & 0.28 & 0.30 & 0.26 & 0.25 & 0.36 & 0.34 \\
\hline 29 & 0.38 & --- & 0.34 & 0.32 & 0.29 & 0.29 & 0.28 & 0.28 & 0.26 & 0.29 & 0.35 & 0.34 \\
\hline 30 & 0.38 & --- & 0.36 & 0.32 & 0.28 & 0.28 & 0.27 & 0.27 & 0.27 & 0.31 & 0.34 & 0.34 \\
\hline 31 & 0.38 & --- & 0.36 & --- & 0.28 & -- & 0.27 & 0.25 & --- & 0.33 & -- & 0.34 \\
\hline TOTAL & 12.65 & 9.89 & 10.33 & 9.94 & 9.29 & 8.37 & 8.11 & 8.02 & 7.72 & 7.94 & 10.49 & 11.01 \\
\hline MEAN & 0.41 & 0.35 & 0.33 & 0.33 & 0.30 & 0.28 & 0.26 & 0.26 & 0.26 & 0.26 & 0.35 & 0.36 \\
\hline MAX & 0.43 & 0.40 & 0.36 & 0.36 & 0.35 & 0.31 & 0.40 & 0.31 & 0.29 & 0.33 & 0.38 & 0.44 \\
\hline MIN & 0.38 & 0.32 & 0.31 & 0.29 & 0.25 & 0.25 & 0.22 & 0.24 & 0.23 & 0.21 & 0.33 & 0.32 \\
\hline MED & 0.41 & 0.36 & 0.34 & 0.33 & 0.30 & 0.28 & 0.27 & 0.25 & 0.26 & 0.25 & 0.35 & 0.34 \\
\hline AC-FT & 25 & 20 & 20 & 20 & 18 & 17 & 16 & 16 & 15 & 16 & 21 & 22 \\
\hline $\begin{array}{c}\text { Calendar year } \\
2009 \\
\end{array}$ & \multicolumn{2}{|c|}{ Total 113.8} & \multicolumn{2}{|c|}{ Mean 0.31} & Max 0.44 & Min 0.21 & \multicolumn{2}{|c|}{ Median 0.32} & \multicolumn{2}{|c|}{ Acre-ft 226} & & \\
\hline
\end{tabular}


Table 15. Period of record for monitoring program streamflowgaging stations and drainage areas for streamflow-gaging stations, Black Mesa area, northeastern Arizona.

[Dashes indicate not determined]

\begin{tabular}{lccc}
\hline \multicolumn{1}{c}{ Station name } & $\begin{array}{c}\text { Station } \\
\text { number }\end{array}$ & $\begin{array}{c}\text { Date data } \\
\text { collection } \\
\text { began }\end{array}$ & $\begin{array}{c}\text { Drainage area } \\
\text { (square miles) }\end{array}$ \\
\hline $\begin{array}{l}\text { Moenkopi Wash at } \\
\text { Moenkopi }\end{array}$ & 09401260 & July 1976 & 1,629 \\
$\begin{array}{l}\text { Dinnebito Wash } \\
\text { near Sand Springs } \\
\text { Polacca Wash near } \\
\text { Second Mesa } \\
\text { Pasture Canyon }\end{array}$ & 09401110 & June 1993 & 473 \\
Springs & 09400568 & April 1994 & 905 \\
\hline
\end{tabular}

Precipitation is another variable to consider when evaluating for trends in annual discharge. Higher precipitation would generally lead to greater annual discharge at a streamflow-gaging station. The average annual precipitation measured at Navajo National Monument (Betatakin; fig. 1) from 1976 to 2009 was 12.6 in. (fig. 10B). Annual precipitation at Betatakin was mostly less than that average from 1995 through 2002 (11.4 in.); precipitation data were incomplete for 2003, above average for calendar year 2004 and 2005 (17.4 in.), below average for calendar years 2006 (11.24 in.) and 2007 (8.26 in.; fig. 10B), above average for 2008 (16.63 in.; fig. 10B), and well below average for 2009 (6.58 in.; fig. $10 B$ ).

Trends in the groundwater-discharge component of total flow at the three streamflow-gaging stations were evaluated on the basis of the median flow for 120 consecutive daily mean flows for 4 winter months (November, December, January, and February) as a surrogate measure for base flow (fig. 11). Groundwater discharge was assumed to be constant throughout the year, and the median winter flow was assumed to represent the constant annual groundwater discharge. Most flow that occurs during the winter is groundwater discharge; rainfall and snowmelt runoff are infrequent. Most of the precipitation in the winter falls as snow, and the cold temperatures prevent appreciable snowmelt. Evapotranspiration is at a minimum during the winter. Rather than the average flow, the median flow for November, December, January, and February is used to estimate groundwater discharge because the median is less affected by occasional winter runoff. Nonetheless, the median flow for November, December, January, and February is an index of groundwater discharge rather than an absolute estimate of groundwater discharge. A more rigorous and accurate estimate would involve detailed evaluations of streamflow hydrographs, flows into and out of bank storage, gain and loss of streamflow as it moves down the stream channel, and interaction of groundwater in the $\mathrm{N}$ aquifer with groundwater in the shallow alluvial aquifers in the stream valleys. The median winter flow, however, is useful as a consistent index for evaluating possible time trends in groundwater discharge.

Median winter flows calculated for the 2009 water year were $2.3 \mathrm{ft}^{3} / \mathrm{s}$ for Moenkopi Wash at Moenkopi, 0.39 $\mathrm{ft} 3 / \mathrm{s}$ for Dinnebito Wash near Sand Springs, $0.22 \mathrm{ft} 3 / \mathrm{s}$ for Polacca Wash near Second Mesa, and $0.34 \mathrm{ft}^{3} / \mathrm{s}$ for Pasture Canyon Springs (fig. 11A-D). For the period of record at each streamflow-gaging station, there have been no significant trends in median winter flows, as indicated by trends calculated by using the method of least squares and Kendall's tau (p>0.05; fig. $11 A-D)$.

\section{Water Chemistry}

Water samples for water-chemistry analyses are collected each year from selected wells and springs as part of the Black Mesa monitoring program. Field measurements are made and water samples are analyzed for major ions, trace elements, nutrients, iron, boron, and arsenic. Field measurements are made in accordance with standard USGS protocols documented in the USGS National Field Manual for the Collection of Water-Quality Data and in several USGS Techniques of Water-Resources Investigations Reports (Friedman and Erdmann, 1982; Koterba and others, 1995; Wilde, 2005, Lane and others, 2003, Wilde, 2004; Wilde and Radtke, 1998; and U.S. Geological Survey, 2006). Field measurements include pH, specific conductance, temperature, dissolved oxygen, alkalinity, and discharge rates at springs. Field alkalinities were determined using incremental equivalence (Wilde and Radtke, 1998). Major ion, nutrient, trace element, iron, boron, arsenic and alkalinity samples were filtered through a 0.45 -micron pore size filter and preserved according to sampling and analytical protocol. Laboratory analyses for samples were done at the USGS National Water Quality Laboratory (NWQL) according to techniques described in Fishman and Friedman (1989), Fishman (1993), Struzeski and others (1996), and Garbarino and others (2006).

Quality control for this study was maintained through the use of proper training of field personnel, use of standard USGS field and lab protocols, collection of an equipment sample blank, collection of a field sample blank, and a thorough review of the analytical results. All USGS scientists involved with this study have participated in the USGS National Field Quality Assurance Program, which requires participants to successfully determine $\mathrm{pH}$, specific conductance and alkalinity of reference samples supplied by the USGS Branch of Quality Systems. Field personnel were trained in water-quality field methods by USGS personnel or through formal instruction at the USGS waterquality field-methods class.

Water-chemistry samples have been collected from 12 wells; 4 of the wells have been sampled every year, and the other 8 wells have been selected on the basis of a sampling 
rotation. In 2010, water samples were collected at 11 well sites: Second Mesa PM2, Keams Canyon PM2, Kykotsmovi PM2, Piñon NTUA 1, Forest Lake NTUA 1, Kits'iili NTUA 2, Rough Rock PM5, Peabody 2, Peabody 6, Kayenta PM2, and Dennehotso PM2. Since 1989, samples have been collected from the same four springs (Moenkopi School Spring, Pasture Canyon Spring, Unnamed spring near Dennehotso, and Burro Spring), and in 2010 all four springs were sampled. Long-term data for specific conductance, dissolved solids, chloride, and sulfate for the wells and springs sampled each year are shown in the reports published each year. These constituents are monitored on an annual basis because increased concentrations in the $\mathrm{N}$ aquifer could indicate leakage from the overlying D aquifer. On average, the concentrations of dissolved solids in water from the D aquifer is about 7 times greater than that of water from the $\mathrm{N}$ aquifer; concentration of chloride ions is about 11 times greater, and concentration of sulfate ions is about 30 times greater (Eychaner, 1983). Historical data for other constituents for all the wells and springs in the Black Mesa study area are available from the USGS water-quality database (http://waterdata.usgs.gov/az/nwis/qw), and they can be found in the past monitoring reports cited in the "Previous Investigations" section of this report.

\section{Water-Chemistry Data for Wells Completed in the N Aquifer}

The primary types of water in the $\mathrm{N}$ aquifer in the Black Mesa study area are calcium bicarbonate water and sodium bicarbonate water. Calcium bicarbonate water generally is in the recharge and unconfined areas of the northern and northwestern parts of the Black Mesa study area, and sodium bicarbonate water is generally in the area that is confined and downgradient to the south and east (Lopes and Hoffmann, 1997). Results from the 2010 sampling are presented in figures 8 and 12 and in table 16 .

Rough Rock PM5 yielded the highest dissolved-solids concentration $(635 \mathrm{mg} / \mathrm{L})$ as well as the highest chloride concentration $(129 \mathrm{mg} / \mathrm{L})$ of the 11 wells sampled (table 16 and fig. 13). Dissolved-solids concentrations in the other 10 wells

\section{A. Annual average discharge for calendar years 1977-2009}

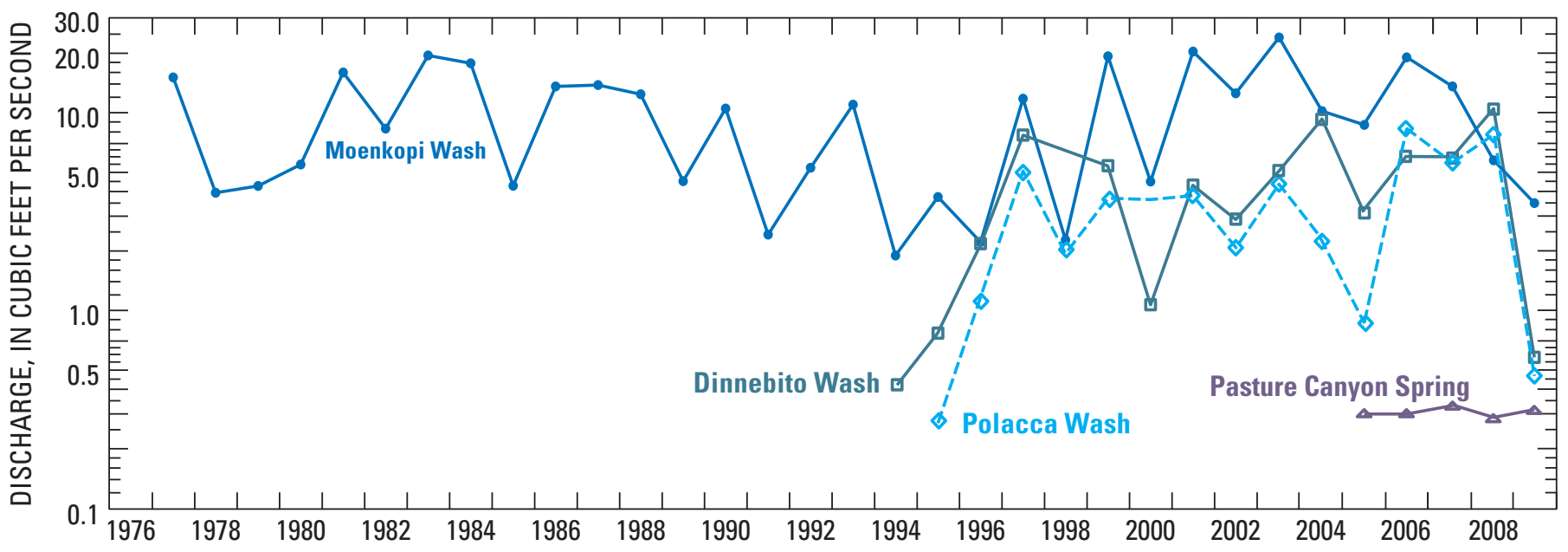

B. Annual precipitation at Betatakin, Arizona, calendar years 1976-2009 (National Weather Service)

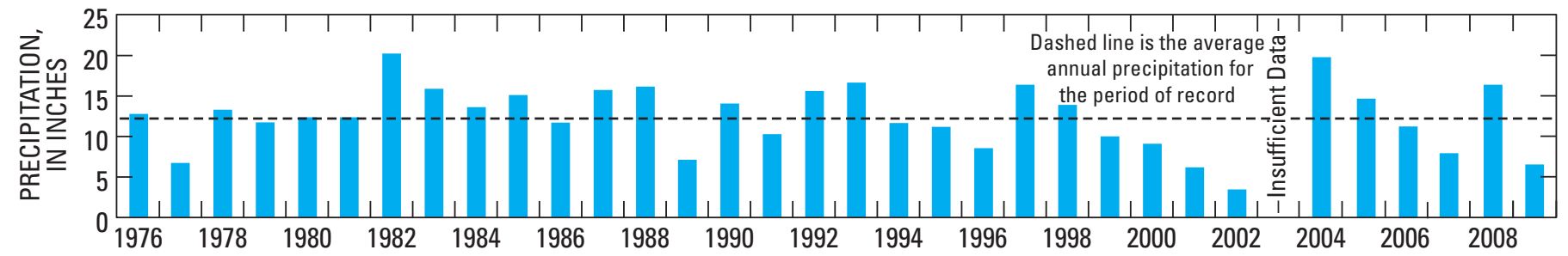

Figure 10. Annual average discharge at Moenkopi Wash at Moenkopi (09401260), Pasture Canyon Springs near Tuba City (09401265), Dinnebito Wash near Sand Springs (09401110), and Polacca Wash near Second Mesa (09400568), and annual precipitation at Betatakin, Arizona, Black Mesa area, northeastern Arizona. A, Annual average discharge for calendar years 1977-2009; $B$, Annual precipitation at Betatakin, northeastern Arizona, calendar years 1976-2009 (National Park Service, Betatakin National Monument, written commun., 2010). 
ranged from $119 \mathrm{mg} / \mathrm{L}$ at Peabody 2 to $607 \mathrm{mg} / \mathrm{L}$ at Keams Canyon PM2, and their chloride concentrations ranged from $1.7 \mathrm{mg} / \mathrm{L}$ at Peabody 6 to $104 \mathrm{mg} / \mathrm{L}$ at Keams Canyon PM2 (table 16 and fig. 13). Forest Lake NTUA 1 had the highest sulfate concentration $(125 \mathrm{mg} / \mathrm{L})$ of the 11 wells, and the concentrations at the other wells ranged from $4.7 \mathrm{mg} / \mathrm{L}$ at Kits'iili NTUA 2 to $114 \mathrm{mg} / \mathrm{L}$ at Rough Rock PM5 (table 16 and fig. 13).

Samples from 1998 to present at Piñon NTUA 1 have shown varying sulfate concentrations, from 4.7 to $83 \mathrm{mg} / \mathrm{L}$ (table 17). Purge times greater than 12 hours from Piñon NTUA 1 appear to induce leakage from the overlying D aquifer and result in higher sulfate concentrations in samples. The confining layer, Carmel Formation, in the area of Piñon is about $120 \mathrm{ft}$ thick and composed of a more sandy siltstone rather than the clayey siltstone observed in the northern part of the study area, where leakage has not been detected (Truini and Macy, 2005). Areas where the Carmel Formation is $120 \mathrm{ft}$ thick or less coincide with areas where ${ }^{87} \mathrm{Sr} /{ }^{86} \mathrm{Sr}$ values and major-ion data for groundwater indicate that $\mathrm{D}$ aquifer water has mixed with $\mathrm{N}$ aquifer water as a result of leakage (Truini and Longsworth, 2003). Both the lithologic difference in the Carmel Formation near Piñon and the thickness of the Carmel Formation near Piñon indicate that leakage could be possible. Purge times may have an effect on samples taken from Piñon NTUA 1 and will be more closely monitored during future sampling.

Chemical constituents analyzed from the 11 wells were compared to the U.S. Environmental Protection Agency (USEPA) primary and secondary drinking water standards (U.S. Environmental Protection Agency, 2003). Maximum Contaminant Levels (MCLs), which are the primary regulations, are legally enforceable standards that apply to public water systems. MCLs protect drinking-water quality by limiting the levels of specific contaminants that can adversely affect public health. Secondary Maximum Contaminant Levels (SMCLs) provide guidelines for the control of contaminants that may cause cosmetic effects (such as skin or tooth discoloration) or aesthetic effects (such as taste, odor, or color) in drinking water. The USEPA recommends compliance with SMCLs for public water systems, however, compliance is not enforced.

In 2010, most of the analyzed constituents from the 11 wells were below the USEPA MCL or SMCL for drinking water. Three of the 11 wells sampled exceeded the USEPA MCL for arsenic $(10.0 \mu \mathrm{g} / \mathrm{L})$ : Second Mesa PM2 with a concentration of $19.1 \mu \mathrm{g} / \mathrm{L}$, Rough Rock PM5 with a concentration of $48.5 \mu \mathrm{g} / \mathrm{L}$, and Keams Canyon PM2 with a concentration of $47.6 \mu \mathrm{g} / \mathrm{L}$. The USEPA SMCL for concentration of dissolved solids $(500 \mathrm{mg} / \mathrm{L})$ was exceeded at Keams Canyon PM2 (607 mg/L), Forest Lake NTUA 1 (503 mg/L), and Rough Rock PM5 $(635 \mathrm{mg} / \mathrm{L})$. In addition, the USEPA SMCL for $\mathrm{pH}$ (6.5 to 8.5) was exceeded at Keams Canyon PM2, Kykotsmovi PM2, Piñon NTUA 1, Forest Lake NTUA 1, Kits'iili NTUA 2, Rough Rock PM5, Peabody 2, Peabody 6, and Dennehotso PM2 (U.S. Environmental Protection Agency, 2003; table 16).

\section{Water-Chemistry Data for Springs that Discharge from the N Aquifer}

In 2010, water samples were collected from Burro Spring, Moenkopi School Spring, Pasture Canyon Spring, and Unnamed Spring near Dennehotso (fig. 8). These four springs discharge water from the unconfined part of the $\mathrm{N}$ aquifer. At Moenkopi School Spring, samples were collected from a horizontal metal pipe that is developed into the hillside. At Pasture Canyon Spring, samples were collected from a pipe at the end of a channel that is approximately $50 \mathrm{ft}$ away from the spring. At Burro Spring, samples were collected from the end of a pipe that fills a trough for cattle. At Unnamed Spring near Dennehotso samples were collected from a pool along the bedrock wall from which the spring discharges.

The samples from all four springs yielded a calcium bicarbonate-type water (fig. 12 and table 18). Samples from Burro Spring, Moenkopi School Spring, Pasture Canyon Spring, and Unnamed Spring near Dennehotso had dissolved solid concentrations of $355 \mathrm{mg} / \mathrm{L}, 217 \mathrm{mg} / \mathrm{L}, 157 \mathrm{mg} / \mathrm{L}$, and $155 \mathrm{mg} / \mathrm{L}$, respectively (tables 18 and 19). Concentration of chloride was highest at Moenkopi School Spring $(26 \mathrm{mg} / \mathrm{L}$; tables 18 and 19). Concentration of sulfate was highest at Burro Spring (71.5 mg/L; tables 18 and 19). Concentrations of all the analyzed constituents in samples from all four springs were less than current USEPA MCLs and SMCLs (U.S. Environmental Protection Agency, 2003).

There are significant increasing trends in concentrations of dissolved solids, chloride, and sulfate in water from Moenkopi School Spring ( $<<0.05$; table 19 and fig. 14). Concentrations of the same constituents in Pasture Canyon Spring, Burro Spring, and Unnamed Spring near Dennehotso did not show any significant trends ( $p>0.05$; table 19 and fig. 14).

\section{Summary}

The $\mathrm{N}$ aquifer is an extensive aquifer and the primary source of groundwater for industrial and municipal users in the Black Mesa area of northeastern Arizona. Availability of water is an important issue in the Black Mesa area because of continued industrial and municipal use, a growing population, and limited precipitation of about 6 to 14 inches per year.

This report presents results of groundwater, surfacewater, and water-chemistry monitoring in the Black Mesa area from January 2009 to September 2010. The monitoring data for 2009-10 are compared to data for 2008-09 and to historical data from the 1950s to September 2010.

In 2009, total groundwater withdrawals were 4,230 acre-ft, industrial withdrawals were 1,390 acre-ft, and municipal withdrawals were 2,840 acre-ft. From 2008 to 2009, total withdrawals from the $\mathrm{N}$ aquifer increased by 3 percent, industrial withdrawals increased by approximately 15 percent, and total municipal withdrawals decreased by 2 percent. 
A. Median winter flow for November, December, January, February, 1977-2009, Moenkopi Wash at Moenkopi (09401260).

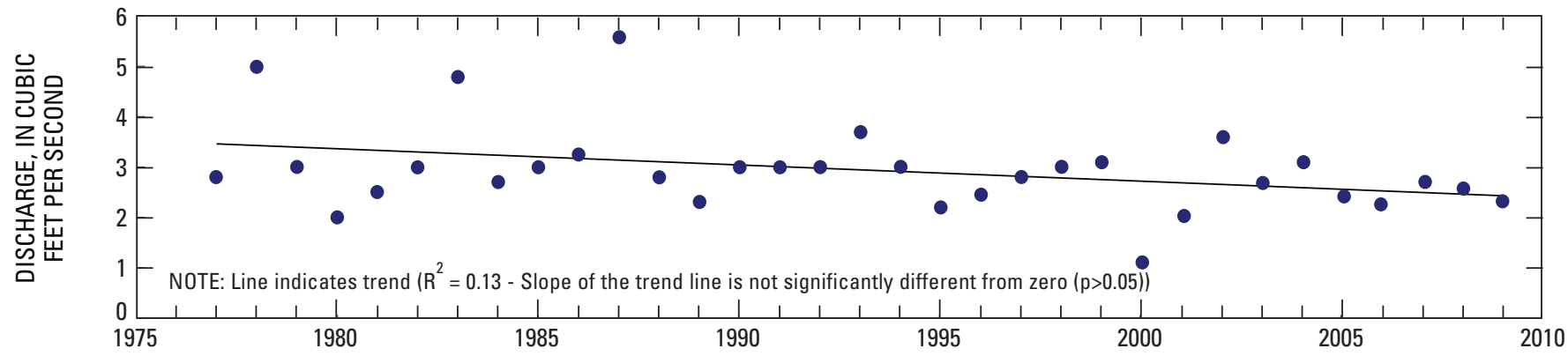

B. Median winter flow for November, December, January, February, 1996-2009, Dinnebito Wash near Sand Springs (09401110).

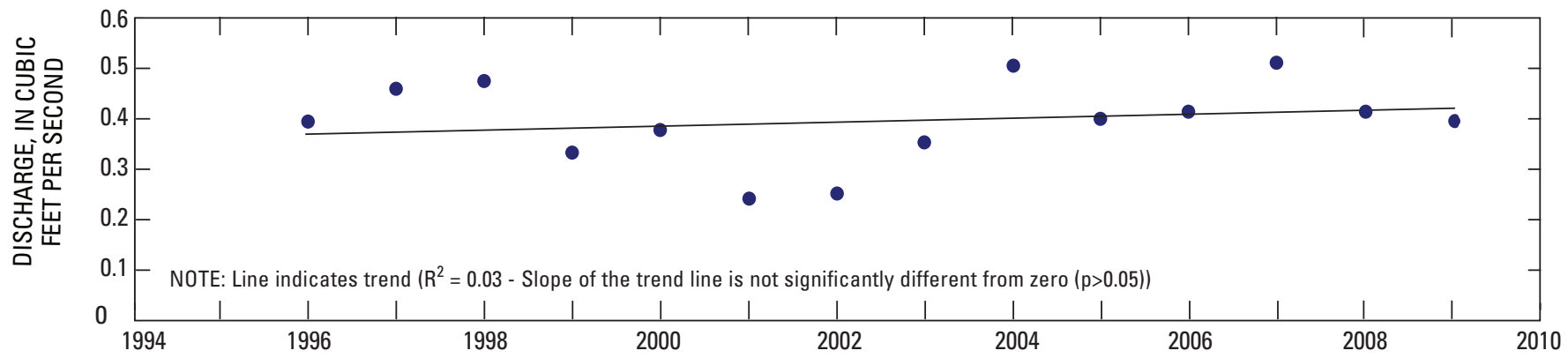

C. Median winter flow for November, December, January, February, 1996-2009, Polacca Wash near Second Mesa (09400568).

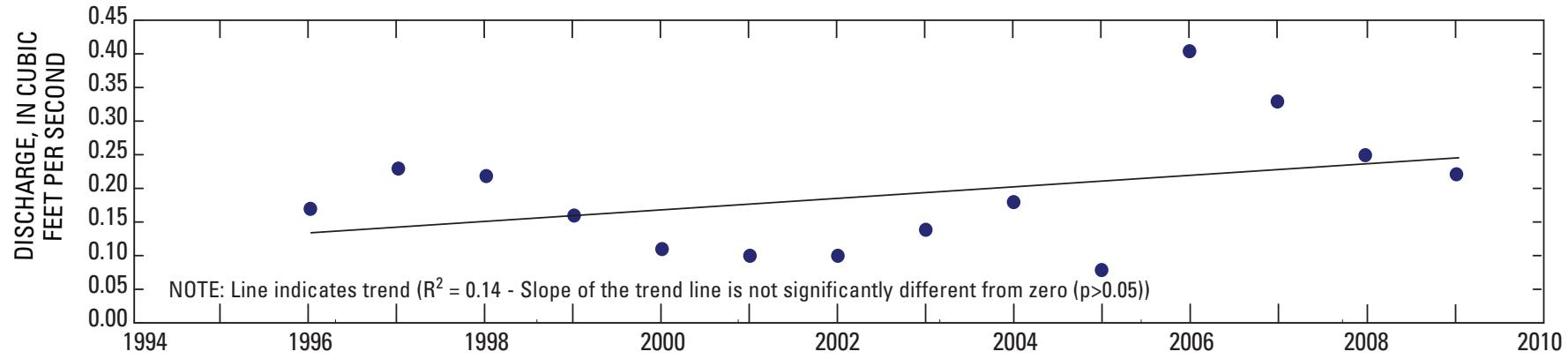

D. Median winter flow for November, December, January, February, 2004-09, Pasture Canyon Springs (09401265).

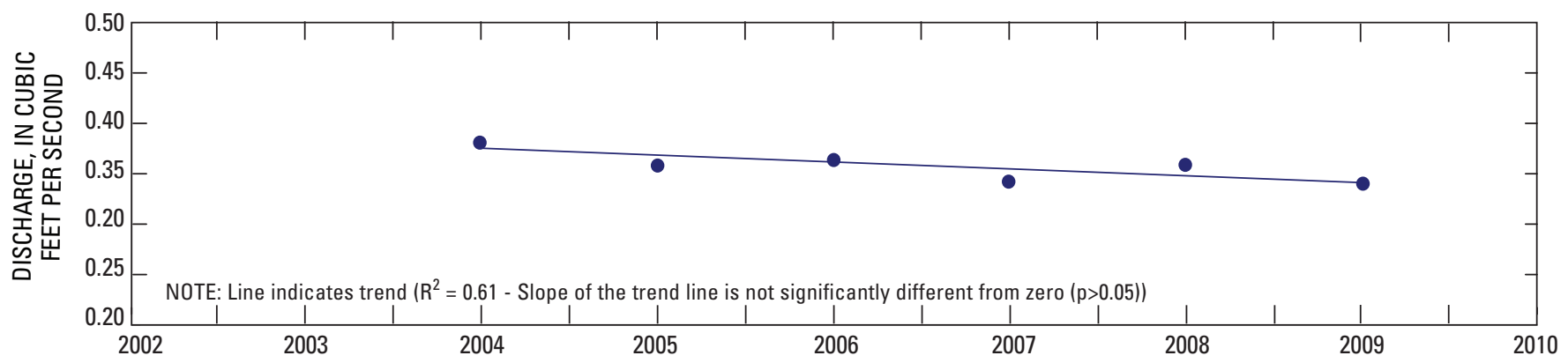

Figure 11. Median winter flow for November, December, January, and February for water years 1977-2009 for $A$, Moenkopi Wash at Moenkopi (09401260), B, Dinnebito Wash near Sand Springs (09401110), C, Polacca Wash near Second Mesa (09400568), and D, Pasture Canyon Springs (09401265), Black Mesa area, northeastern Arizona. Median winter flow is calculated by computing the median flow for 120 consecutive daily mean flows for winter months—November, December, January, and February. Note: Trend lines were generated by using the method of least squares. 


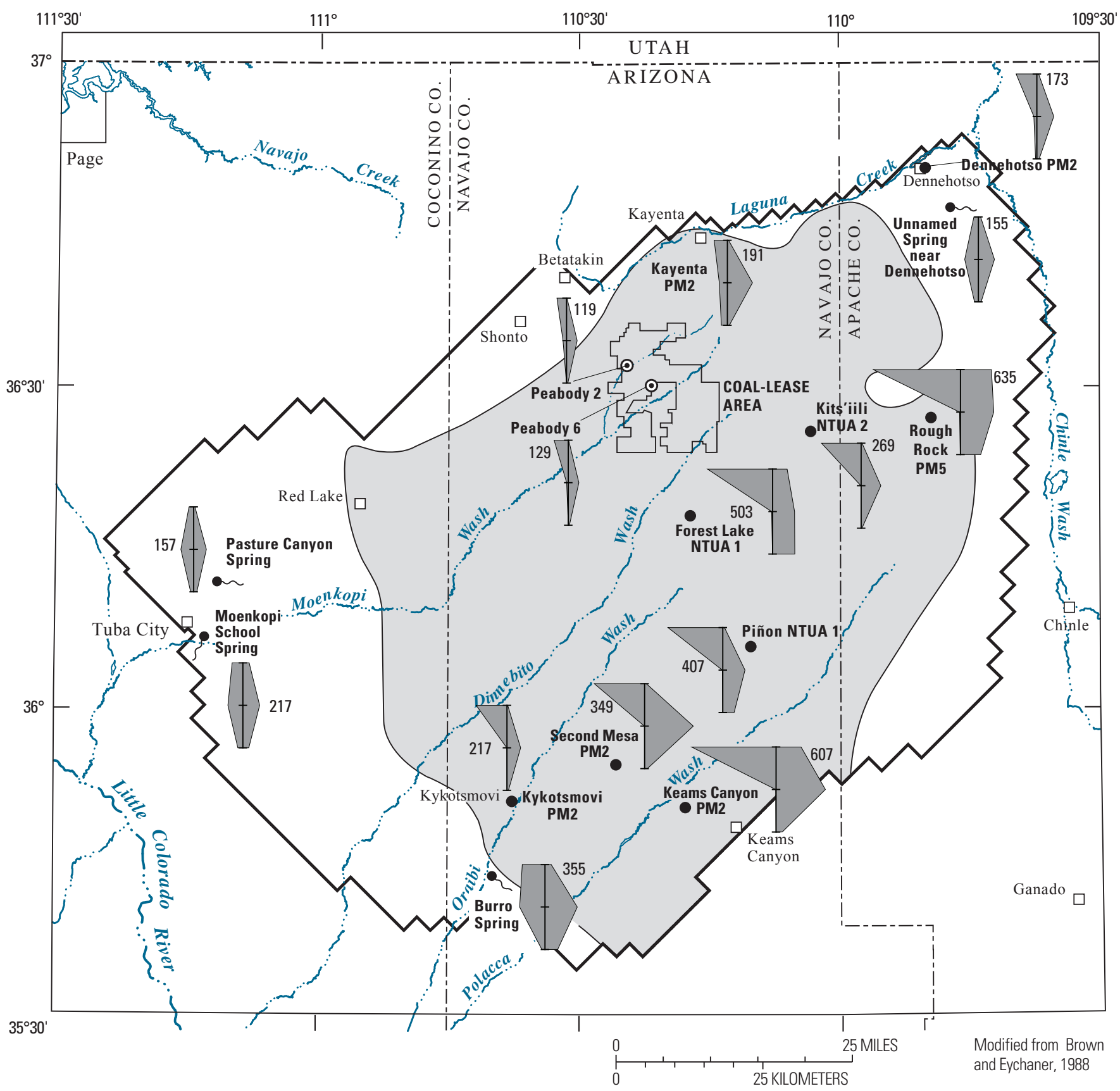

EXPLANATION

CONFINED AND UNCONFINED CONDITIONS IN THE N AQUIFER WITHIN MODEL BOUNDARY

\begin{tabular}{|c|c|}
\hline & Confined \\
\hline & Unconfined \\
\hline & $\begin{array}{l}\text { APPROXIMATE BOUNDARY BETWEEN } \\
\text { CONFINED AND UNCONFINED CONDITIONS- } \\
\text { From Brown and Eychaner (1988) }\end{array}$ \\
\hline & $\begin{array}{l}\text { BOUNDARY OF MATHEMATICAL MODEL- } \\
\text { From Brown and Eychaner (1988) }\end{array}$ \\
\hline
\end{tabular}

\begin{tabular}{|c|c|}
\hline$\underset{\substack{\text { Kykotsmovi } \\
\text { PM2 }}}{\bullet}$ & $\begin{array}{l}\text { MUNICIPAL WELL FROM WHICH } \\
\text { WATER-CHEMISTRY SAMPLE } \\
\text { WAS COLLECTED-Kykotsmovi } \\
\text { PM2 is well name }\end{array}$ \\
\hline 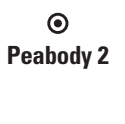 & $\begin{array}{l}\text { INDUSTIAL WELL FROM WHICH } \\
\text { WATER-CHEMISTRY SAMPLE WAS } \\
\text { COLLECTED-Peabody } 2 \text { is a well } \\
\text { number }\end{array}$ \\
\hline $\begin{array}{l}\text { Pasture } \\
\text { Canyon } \\
\text { Spring }\end{array}$ & $\begin{array}{l}\text { SPRING AT WHICH DISCHARGE WAS } \\
\text { MEASURED AND WATER-CHEMISTRY } \\
\text { SAMPLE WAS COLLECTED }\end{array}$ \\
\hline
\end{tabular}

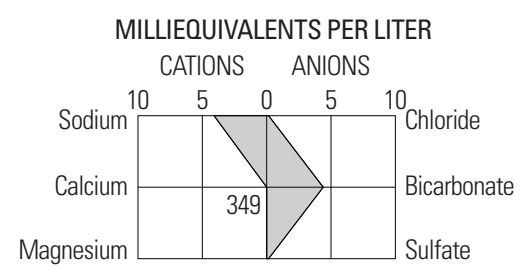

Water-chemistry Diagram-Shows major chemical constituents in milliequivalents per liter (meq/L). The diagram can be used to compare and characterize types of water. Number, 349, is dissolved-solids

Figure 12. Water chemistry and distribution of dissolved solids in the N aquifer, Black Mesa area, northeasern Arizona, 2010. 
Table 16. Physical properties and chemical analyses of water samples from selected industrial and municipal wells completed in the $\mathrm{N}$ aquifer, Black Mesa area, northeastern Arizona, 2010.

$\left[{ }^{\circ} \mathrm{C}\right.$, degrees Celsius; $\mu \mathrm{S} / \mathrm{cm}$, microsiemens per centimeter at $25^{\circ} \mathrm{C} ; \mathrm{mg} / \mathrm{L}$, milligrams per liter; E, estimated; $\mu \mathrm{g} / \mathrm{L}$, micrograms per liter; $<$, less than]

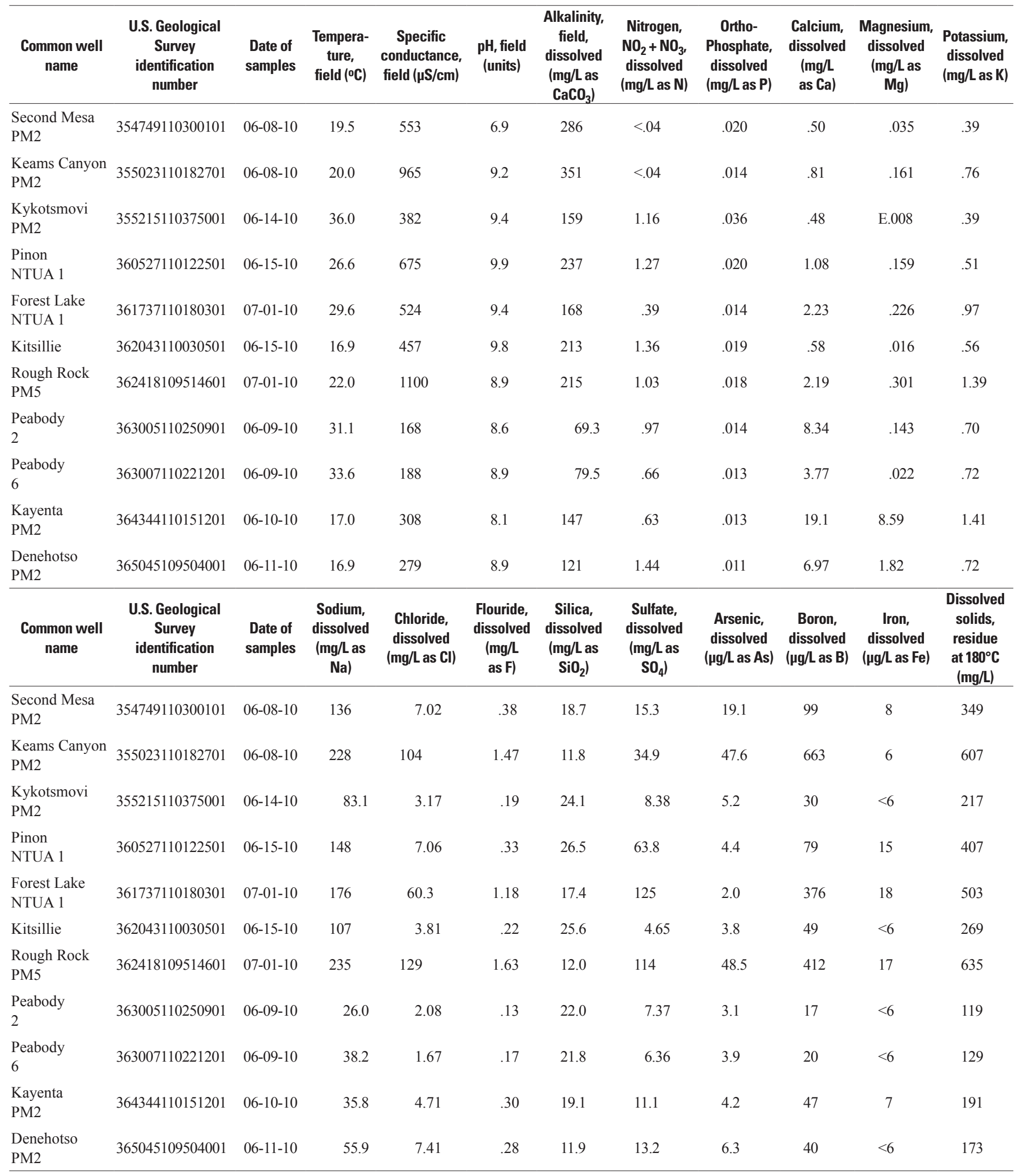


Table 17. Specific conductance and concentrations of selected chemical constituents in water samples from selected industrial and municipal wells completed in the N aquifer, Black Mesa area, northeastern Arizona, 1974-2010.

$\left[\mu \mathrm{S} / \mathrm{cm}\right.$, microsiemens per centimeter at $25^{\circ} \mathrm{C} ;{ }^{\circ} \mathrm{C}$, degrees Celsius; $\mathrm{mg} / \mathrm{L}$, milligram per liter; $<$, less than. Dashes indicate no data]

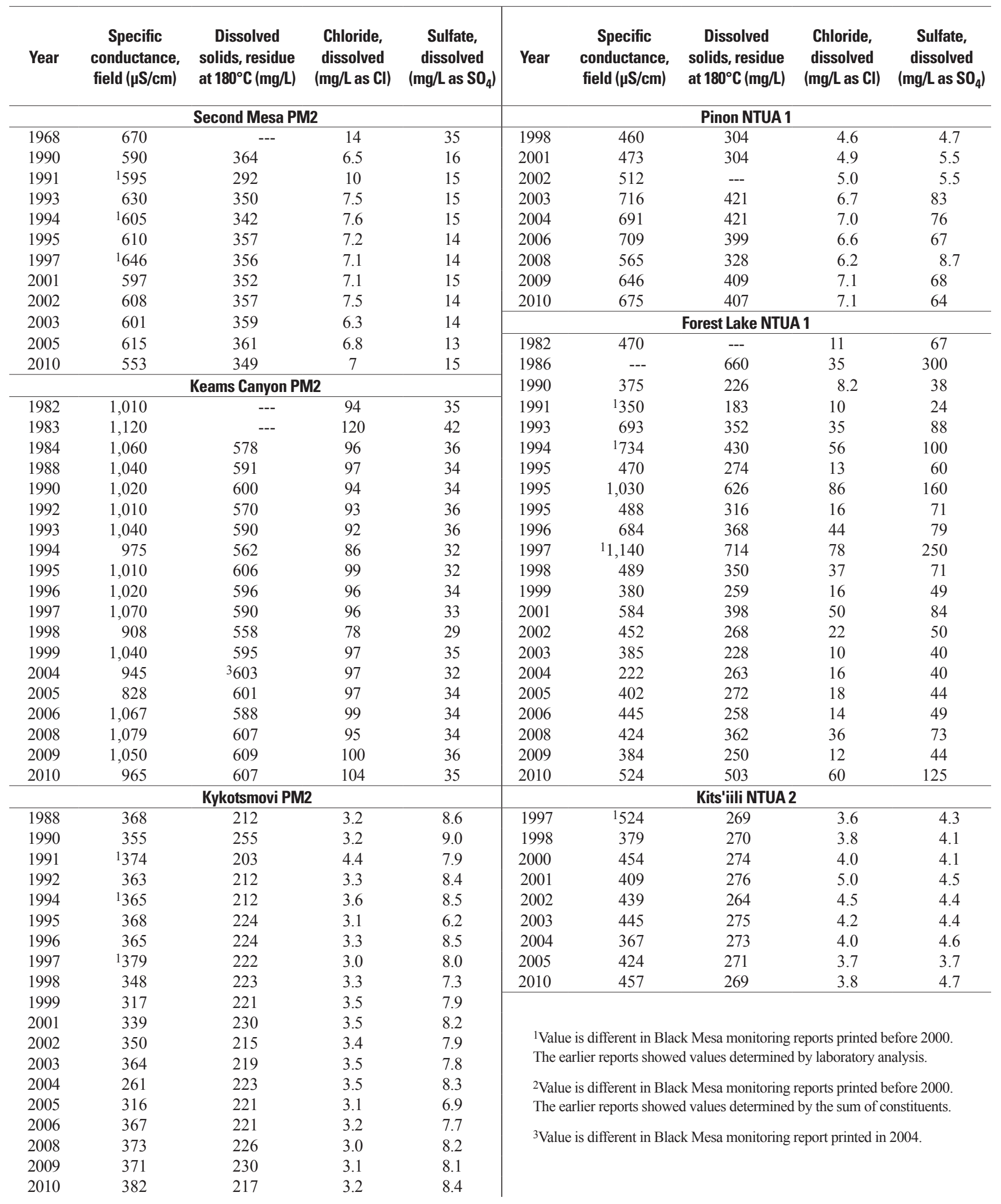


Table 17. Specific conductance and concentrations of selected chemical constituents in water samples from selected industrial and municipal wells completed in the N aquifer, Black Mesa area, northeastern Arizona, 1974-2010.—Continued

$\left[\mu \mathrm{S} / \mathrm{cm}\right.$, microsiemens per centimeter at $25^{\circ} \mathrm{C} ;{ }^{\circ} \mathrm{C}$, degrees Celsius; $\mathrm{mg} / \mathrm{L}$, milligram per liter; $<$, less than. Dashes indicate no data $]$

\begin{tabular}{|c|c|c|c|c|c|c|c|c|c|}
\hline Year & $\begin{array}{c}\text { Specific } \\
\text { conductance, } \\
\text { field ( } \mathrm{S} / \mathrm{cm})\end{array}$ & $\begin{array}{l}\text { Dissolved solids, } \\
\text { residue at } 180^{\circ} \mathrm{C} \\
\text { (mg/L) }\end{array}$ & $\begin{array}{c}\text { Chloride, } \\
\text { dissolved } \\
\text { (mg/L as Cl) }\end{array}$ & $\begin{array}{c}\text { Sulfate, } \\
\text { dissolved } \\
\left(\mathrm{mg} / \mathrm{L} \text { as } \mathrm{SO}_{4}\right)\end{array}$ & Year & $\begin{array}{c}\text { Specific } \\
\text { conductance, } \\
\text { field }(\mu \mathrm{S} / \mathrm{cm})\end{array}$ & $\begin{array}{c}\text { Dissolved } \\
\text { solids, residue } \\
\text { at } 180^{\circ} \mathrm{C}(\mathrm{mg} / \mathrm{L})\end{array}$ & $\begin{array}{l}\text { Chloride, } \\
\text { dissolved } \\
\text { (mg/L as Cl) }\end{array}$ & $\begin{array}{c}\text { Sulfate, } \\
\text { dissolved } \\
\left.\text { (mg/Las } \mathrm{SO}_{4}\right)\end{array}$ \\
\hline \multicolumn{5}{|c|}{ Rough Rock PM5 } & \multicolumn{5}{|c|}{ Peabody 6} \\
\hline 1964 & 1120 & (2) & 100 & 110 & 1968 & 201 & -- & 3.0 & 13 \\
\hline 1970 & 610 & $\left({ }^{2}\right)$ & 13 & 50 & 1974 & 500 & 333 & 11.0 & 40 \\
\hline 1983 & 1,090 & $\left({ }^{2}\right)$ & 130 & 110 & 1977 & 240 & -- & 3.2 & 13 \\
\hline 1984 & ${ }^{1} 1,100$ & 613 & 130 & 99 & 1979 & 260 & -- & 3.2 & 19 \\
\hline 1986 & 1,010 & 633 & 140 & 120 & 1980 & 260 & 160 & 3.5 & 15 \\
\hline 1988 & 1,120 & 624 & 130 & ${ }^{3} 110$ & 1986 & 182 & -- & 2.3 & 9.6 \\
\hline 1991 & ${ }^{1} 1,210$ & 574 & 130 & 110 & 1988 & 173 & 127 & 2.4 & 9.1 \\
\hline 1993 & 1,040 & 614 & 130 & 110 & 1993 & 181 & 126 & 1.9 & 6.6 \\
\hline 1994 & ${ }^{1} 1,180$ & 626 & 130 & 110 & 1996 & 177 & 122 & 1.5 & 6 \\
\hline 1995 & 1,110 & 648 & 140 & 110 & 2005 & 174 & 122 & 1.5 & 5.7 \\
\hline 1996 & 1,100 & 634 & 130 & 110 & 2010 & 188 & 129 & 1.7 & 6.7 \\
\hline 1997 & ${ }^{1} 1,060$ & 628 & 130 & 112 & \multicolumn{5}{|c|}{ Kayenta PM2 } \\
\hline 1998 & 894 & 637 & 133 & 112 & 1982 & 360 & $(2)$ & 4.5 & 58 \\
\hline 1999 & 1,050 & 630 & 129 & 110 & 1983 & 375 & ${ }^{(2)}$ & 5.9 & 60 \\
\hline 2001 & 980 & 628 & 125 & 110 & 1984 & 1370 & 209 & 4.2 & 51 \\
\hline 2002 & 1,120 & 636 & 129 & 109 & 1986 & 300 & 181 & 8.2 & 30 \\
\hline 2003 & 1,080 & 642 & 127 & 110 & 1988 & 358 & 235 & 3.8 & 74 \\
\hline 2004 & 653 & 649 & 128 & 109 & 1992 & 383 & 210 & 5.6 & 78 \\
\hline 2005 & 1053 & 639 & 128 & 113 & 1993 & 374 & 232 & 3.7 & 78 \\
\hline 2010 & 1101 & 635 & 129 & 114 & 1994 & 1371 & 236 & 4.2 & 77 \\
\hline \multicolumn{5}{|c|}{ Peabody 2} & 1995 & 371 & 250 & 4.2 & 72 \\
\hline 1967 & 221 & --- & 5.0 & 21 & 1996 & 370 & 238 & 3.8 & 76 \\
\hline 1971 & 211 & --- & 2.8 & 18 & 1997 & 379 & 230 & 3.9 & 77 \\
\hline 1974 & 210 & 144 & 2.8 & 17 & 1998 & 349 & 236 & 3.7 & 71 \\
\hline 1975 & 230 & 163 & 5.0 & 20 & 1999 & 364 & 236 & 4.0 & 72 \\
\hline 1976 & 260 & 133 & 3.6 & 16 & 2001 & 331 & 234 & 5.0 & 73 \\
\hline 1979 & 220 & --- & 3.4 & 24 & 2002 & 363 & 237 & 5.1 & 67 \\
\hline 1980 & 225 & 145 & 11.0 & 20 & 2003 & 378 & 273 & 5.9 & 88 \\
\hline 1986 & 172 & --- & 2.6 & 8.1 & 2004 & 303 & 241 & 4.0 & 72 \\
\hline 1987 & 149 & 113 & 5.0 & 9.1 & 2005 & 374 & 231 & 3.7 & 76 \\
\hline 1993 & 163 & 124 & 1.7 & 8.9 & 2010 & 308 & 191 & 4.7 & 11 \\
\hline 1998 & 93 & 119 & 2.2 & 7.9 & \multicolumn{5}{|c|}{ Dennehotso PM2 } \\
\hline 1999 & 167 & 115 & 2.3 & 8.1 & 1964 & 350 & --- & 12 & 31 \\
\hline 2005 & 134 & 124 & 2.1 & 8.2 & 1992 & 226 & 131 & 9.8 & 19 \\
\hline 2006 & 167 & 118 & 2.2 & 8.2 & 1993 & 298 & 164 & 8.2 & 16 \\
\hline 2008 & 160 & 120 & 2.0 & 7.5 & 1997 & 1305 & 190 & 11 & 14 \\
\hline 2009 & 146 & 113 & 2.1 & 7.2 & 1999 & 314 & 196 & 14 & 15 \\
\hline \multirow[t]{2}{*}{2010} & 168 & 119 & 2.1 & 7.4 & 2005 & 339 & 205 & 10.5 & 14 \\
\hline & & & & & 2010 & 279 & 173 & 7.4 & 13 \\
\hline
\end{tabular}

${ }^{1}$ Value is different in Black Mesa monitoring reports printed before 2000. The earlier reports showed values determined by laboratory analysis.

${ }^{2}$ Value is different in Black Mesa monitoring reports printed before 2000. The earlier reports showed values determined by the sum of constituents.

${ }^{3}$ Value is different in Black Mesa monitoring report printed in 2004. 
Table 18. Physical properties and chemical analyses of water samples from four springs in the Black Mesa area, northeastern Arizona, 2010.

$\left[{ }^{\circ} \mathrm{C}\right.$, degree Celsius; $\mu \mathrm{S} / \mathrm{cm}$, microsiemens per centimeter at $25^{\circ} \mathrm{C} ; \mathrm{mg} / \mathrm{L}$, milligrams per liter; $\mu \mathrm{g} / \mathrm{L}$, micrograms per liter; $<$, less than.

Dashes indicate no data; e, estimated]

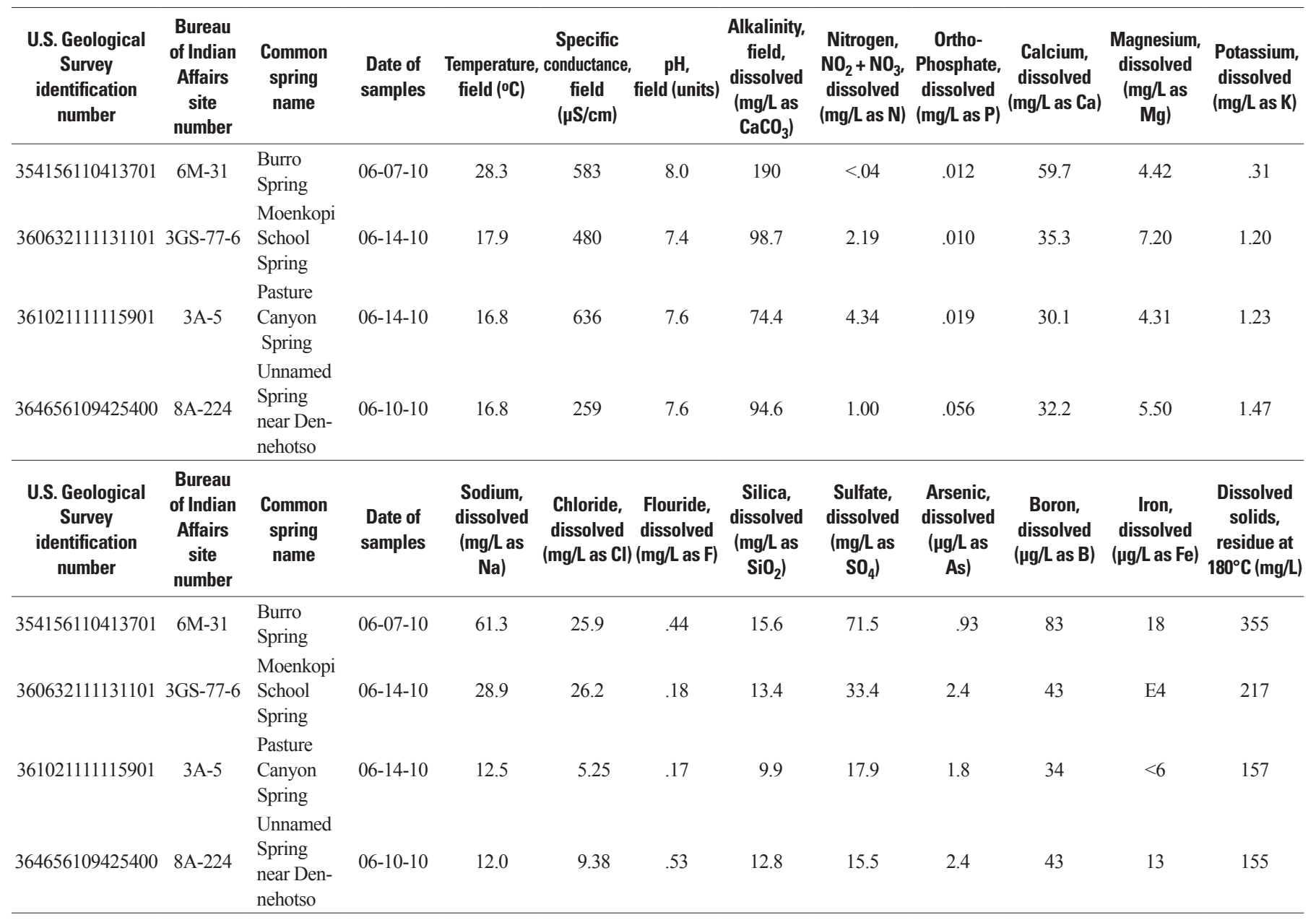

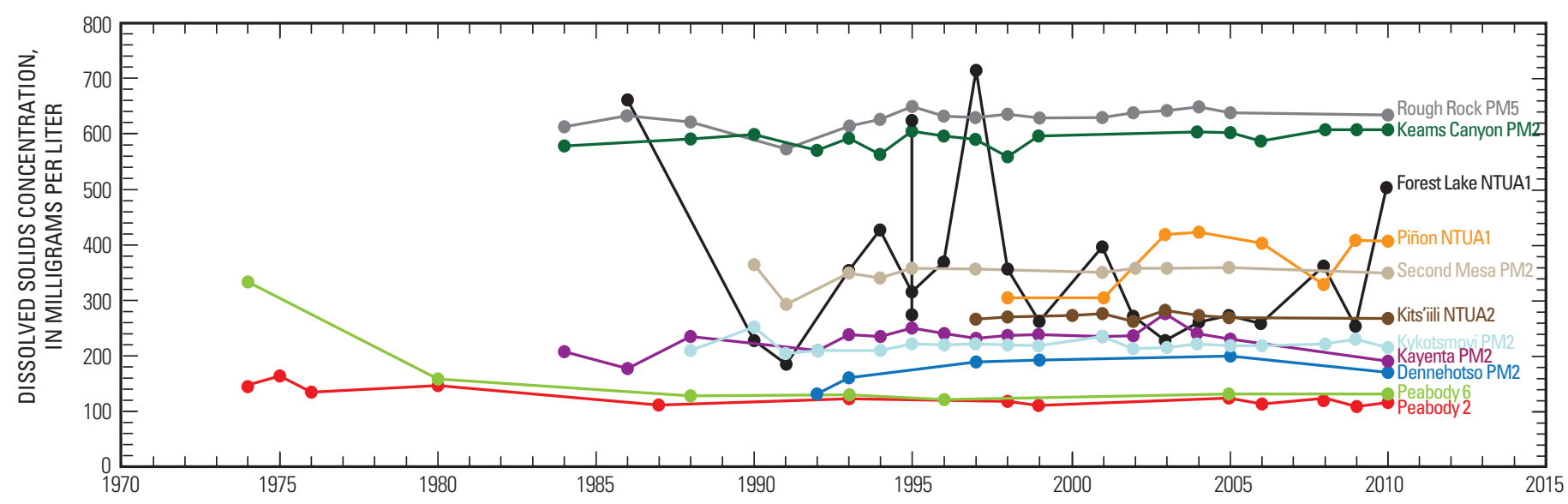

Figure 13. Dissolved-solids concentrations for water samples from selected wells, $\mathrm{N}$ aquifer, Black Mesa area, northeastern Arizona, 1974-2010: Rough Rock PM5, 1984-2010; Keams Canyon PM2, 1984-2010; Forest Lake NTUA 1, 1986-2010; Piñon NTUA 1, 1998-2010; Second Mesa PM2, 1990-2010; Kits'illi NTUA 2, 1997-2010; Kykotsmovi, 1988-2010; Kayenta PM2, 1984-2010; Dennehotso PM2, 1992-2010; Peabody 6, 1974-2010; and Peabody 2, 1974-2010. 
Table 19. Specific conductance and concentrations of selected chemical constituents in $N$ aquifer water samples from four springs in the Black Mesa area, northeastern Arizona, 1948-2010.

$\left[\mu \mathrm{S} / \mathrm{cm}\right.$, microsiemens per centimeter at $25^{\circ} \mathrm{C} ;{ }^{\circ} \mathrm{C}$, degrees Celsius; $\mathrm{mg} / \mathrm{L}$, milligram per liter; $<$, less than. Dashes indicate no data]

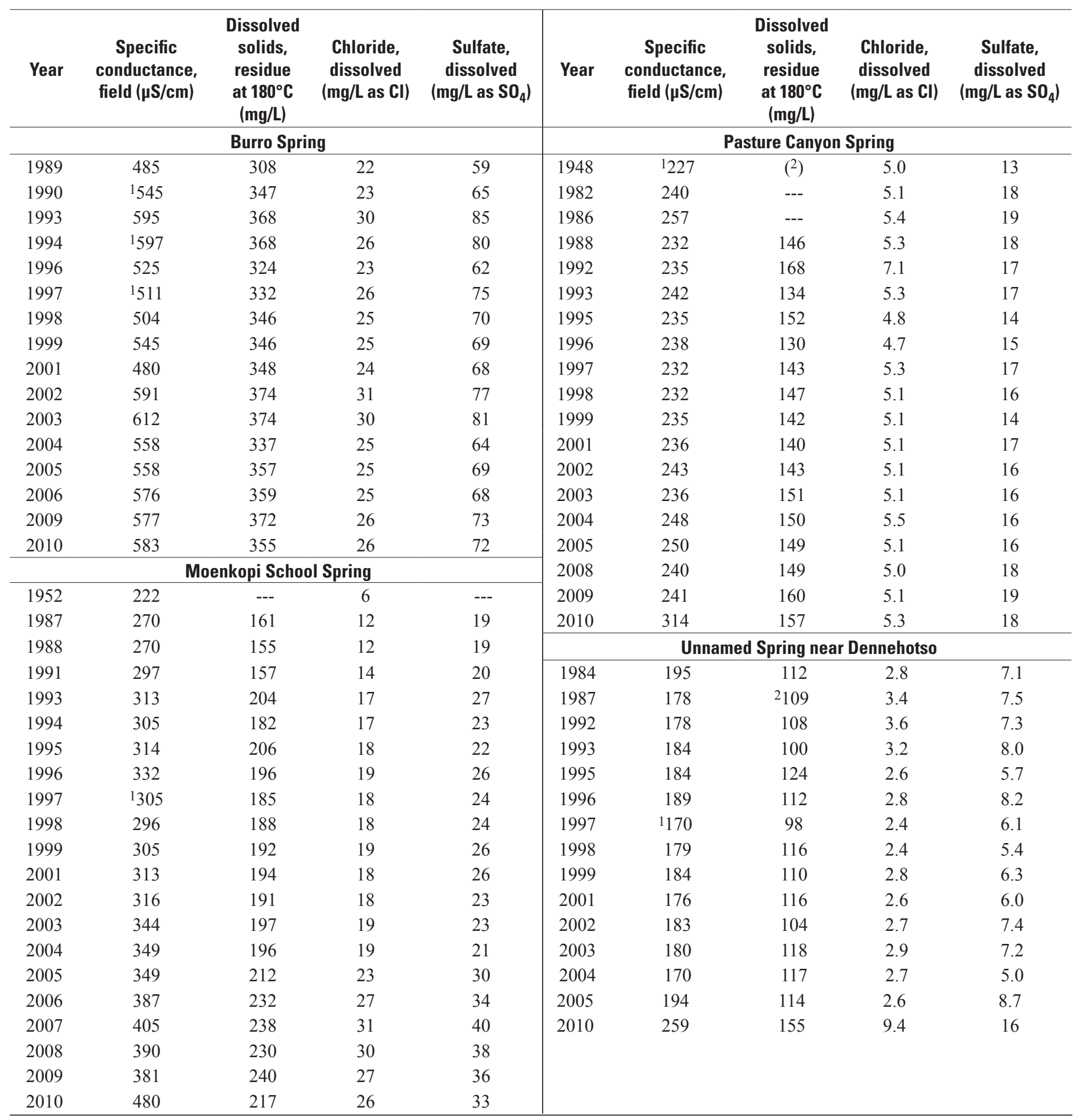

${ }^{1}$ Value is different in Black Mesa monitoring reports before 2000. Earlier reports showed values determined by laboratory analysis.

${ }^{2}$ Value is different in Black Mesa monitoring reports before 2000. Earlier reports showed values determined by the sum of constituents. 
A. Dissolved Solids

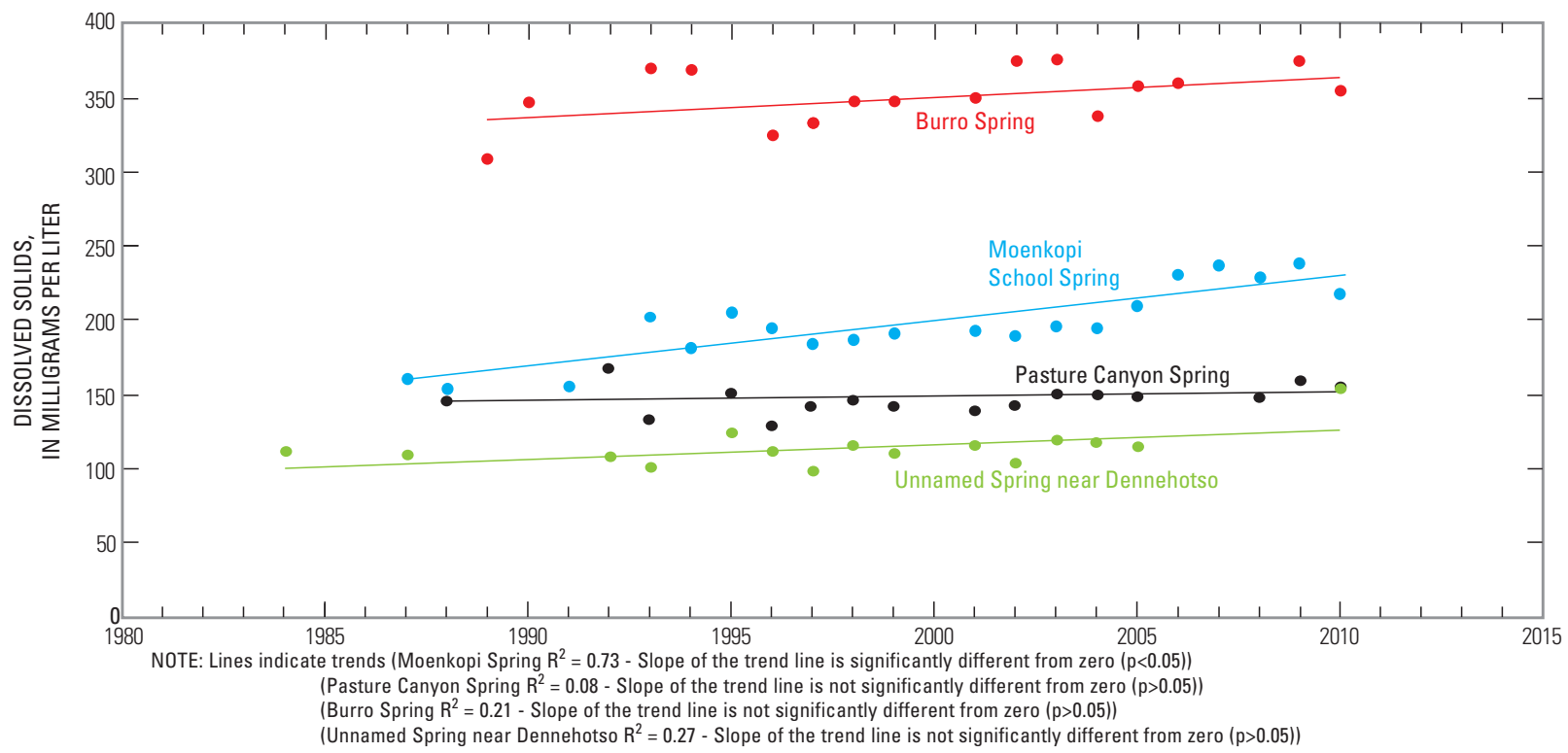

B. Chloride

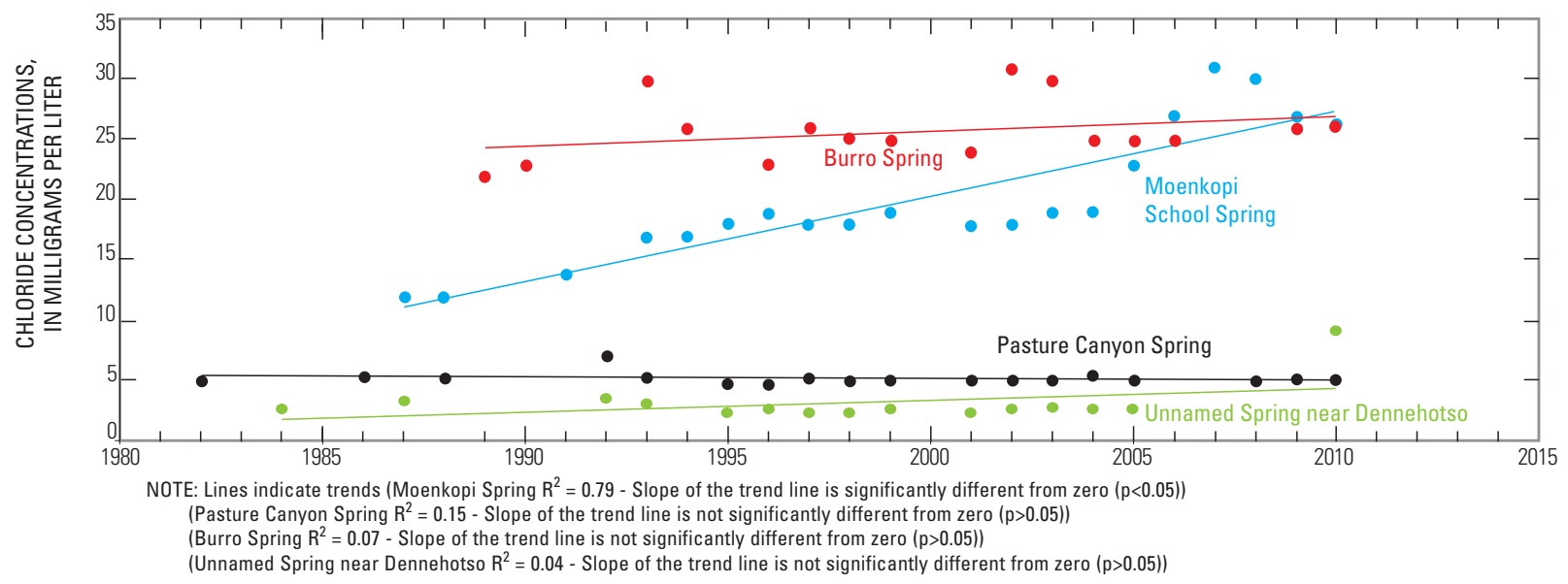

C. Sulfate

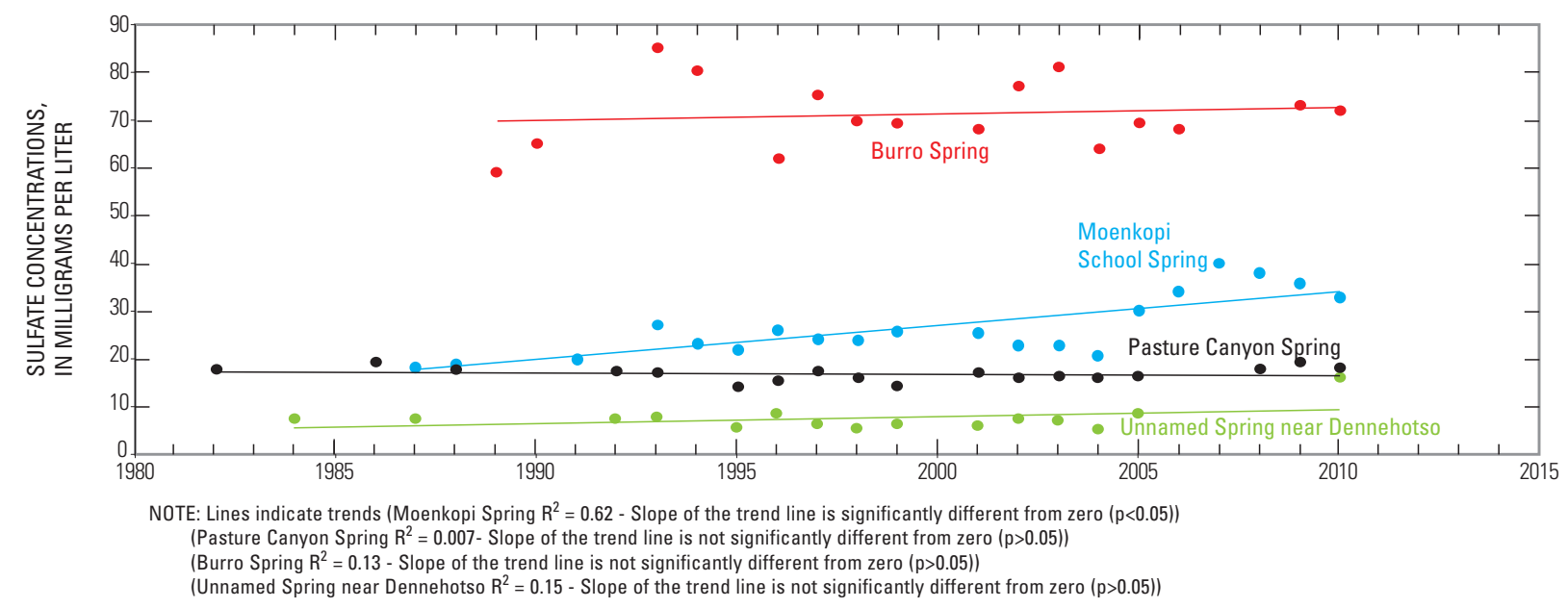

Figure 14. Concentrations of dissolved solids, chloride, and sulfate for water samples from Moenkopi School Spring, Pasture Canyon Sping, Burro Spring and Unnamed Sping near Dennehotso, N aquifer, Black Mesa area, northeastern Arizona, 1982-2010. A, Dissolved solids; $B$, Chloride; $C$, Sulfate. (Trend lines were generated by using the method of least squares). 
From 2009 to 2010, annually measured groundwater levels declined in 19 of 34 wells available for comparison. The median water-level change for the 34 wells was -0.2 $\mathrm{ft}$. In unconfined areas of the $\mathrm{N}$ aquifer, water levels declined in 7 of 16 annual wells available for comparison, and the median change was $0.1 \mathrm{ft}$. In the confined area of the $\mathrm{N}$ aquifer, water levels declined in 12 of 18 wells, and the median change was $-0.3 \mathrm{ft}$. From the prestress period (before 1965) to 2010, the median groundwater level change in 34 wells was $-13.9 \mathrm{ft}$. Water levels in the 16 wells in the unconfined areas of the $\mathrm{N}$ aquifer had a median change of $-0.8 \mathrm{ft}$, and the changes ranged from $-43.9 \mathrm{ft}$ to $+12.9 \mathrm{ft}$. Water levels in the 18 wells in the confined area of the $\mathrm{N}$ aquifer had a median change of $-38.7 \mathrm{ft}$, and the changes ranged from $-212.5 \mathrm{ft}$ to $+14.6 \mathrm{ft}$.

Discharge has been measured annually at Moenkopi School Spring and Pasture Canyon Spring and intermittently at Burro Spring and Unnamed Spring near Dennehotso. Between 2009 and 2010, spring flow decreased by 7.5 percent at Moenkopi School Spring, and spring flow increased by

10 percent at Pasture Canyon Spring. Discharge at Burro Spring and Unnamed Spring near Dennehotso has remained relatively constant since it was first measured. For the period of record, discharge at Moenkopi School Spring and Pasture Canyon Spring has fluctuated, and the data indicate a decreasing trend in discharge for both springs; however, no trend is apparent for either Burro Spring or Unnamed Spring near Dennehotso.

Annual average discharges at four streamflow-gaging stations-Moenkopi Wash, Dinnebito Wash, Pasture Canyon Springs, and Polacca Wash - vary during the periods of record. No trends are apparent in streamflow at the four streamflow-gaging stations. Median flows for November, December, January, and February of each water year are used as an indicator of groundwater discharge to those streams. For the period of record at each streamflowgaging station, the median winter flows have generally remained constant, showing neither a significant increase nor decrease.

In 2010, water samples were collected from 11 wells and 4 springs and analyzed for selected chemical constituents. In the 11 wells, concentrations of dissolved solids, chloride, and sulfate have varied for the period of record, and the data do not indicate a trend.

Dissolved-solids concentrations in water samples from Burro Spring, Moenkopi School Spring, Pasture Canyon Spring, and Unnamed Spring near Dennehotso were 355 $\mathrm{mg} / \mathrm{L}, 217 \mathrm{mg} / \mathrm{L}, 157 \mathrm{mg} / \mathrm{L}$, and $155 \mathrm{mg} / \mathrm{L}$, respectively. From the mid 1980s to 2010, long-term data from Moenkopi School Spring indicate increasing trends in concentrations of dissolved solids, chloride, and sulfate. Concentrations of dissolved solids, chloride, and sulfate from Pasture Canyon Spring, Burro Spring and Unnamed Spring near Dennehotso do not indicate a trend for the period of record.

\section{References}

Boner, F.C., Davis, R.G., and Duet, N.R., 1992, Waterresources data, Arizona, water year 1991: U.S. Geological Survey Water-Data Report AZ-91-1, 411 p.

Boner, F.C., Garrett, W.B., and Konieczki, A.D., 1989, Waterresources data, Arizona, water year 1988: U.S. Geological Survey Water-Data Report AZ-88-1, 391 p.

Boner, F.C., Konieczki, A.D., and Davis, R.G., 1991, Waterresources data, Arizona, water year 1990: U.S. Geological Survey Water-Data Report AZ-90-1, 381 p.

Boner, F.C., Smith, C.F., Garrett, W.B., and Konieczki, A.D., 1990, Water-resources data, Arizona, water year 1989: U.S. Geological Survey Water-Data Report AZ-89-1, 383 p.

Brown, J.G., and Eychaner, J.H., 1988, Simulation of five ground-water withdrawal projections for the Black Mesa area, Navajo and Hopi Indian Reservations, Arizona: U.S. Geological Survey Water-Resources Investigations Report 88-4000, 51 p.

Cooley, M.E., Harshbarger, J.W., Akers, J.P., and Hardt, W.F., 1969, Regional hydrogeology of the Navajo and Hopi Indian Reservations, Arizona, New Mexico, and Utah: U.S. Geological Survey Professional Paper 521-A, 61 p.

Davis, G.E., Hardt, W.F., Thompson, L.K., and Cooley, M.E., 1963, Records of ground-water supplies, part 1 of geohydrologic data in the Navajo and Hopi Indian Reservations, Arizona, New Mexico, and Utah: Arizona State Land Department Water-Resources Report 12-A, 159 p.

Eychaner, J.H., 1983, Geohydrology and effects of water use in the Black Mesa area, Navajo and Hopi Indian Reservations, Arizona: U.S. Geological Survey Water-Supply Paper 2201, 26 p.

Fishman, M.J., ed., 1993, Methods of analysis by the U.S. Geological Survey National Water Quality Laboratory--Determination of inorganic and organic constituents in water and fluvial sediments: U.S. Geological Survey Open-File Report 93-125, 217 p.

Fishman, M.J., and Friedman, L.C., 1989, Methods for determination of inorganic substances in water and fluvial sediments: U.S. Geological Survey Techniques of WaterResources Investigations, book 5, chap. A1, 545 p.

Fisk, G.G., Duet, N.R., Evans, D.W., Angeroth, C.E., Castillo, N.K., and Longsworth, S.A., 2004, Water-resources data, Arizona, water year 2003: U.S. Geological Survey WaterData Report AZ-03-1, 326 p.

Fisk, G.G., Duet, N.R., McGuire, E.H., Angeroth, C.E., Castillo, N.K., and Smith, C.F., 2005, Water-resources data, Arizona, water year 2004: U.S. Geological Survey WaterData Report AZ-04-1, 415 p. 
Fisk, G.G., Duet, N.R., McGuire, E.H., Roberts, W.P., Castillo, N.K., and Smith, C.F., 2006, Water-resources data, Arizona, water year 2005: U.S. Geological Survey Water-Data Report AZ-05-1, 347 p.

Fisk, G.G., Duet, N.R., McGuire, E.H., Castillo, N.K., and Smith, C.F., 2007, Water-resources data, Arizona, water year 2006: U.S. Geological Survey Water-Data Report AZ-06-1.

Fisk, G.G., Duet, N.R., McGuire, E.H., Castillo, N.K., and Smith, C.F., 2008, Water-resources data, Arizona, water year 2007:

U.S. Geological Survey Water-Data Report AZ-07-1.

Fisk, G.G., Duet, N.R., McGuire, E.H., Castillo, N.K., and Smith, C.F., 2009, Water-resources data, Arizona, water year 2008 : U.S. Geological Survey Water-Data Report AZ-08-1.

Fisk, G.G., Duet, N.R., McGuire, E.H., Castillo, N.K., and Smith, C.F., 2010, Water-resources data, Arizona, water year 2009: U.S. Geological Survey Water-Data Report AZ-09-1.

Friedman, L.C., and Erdmann, D.E., 1982, Quality Assurance practices for the chemical and biological analyses of water and fluvial sediments: U.S. Geological Survey Techniques of Water-Resources Investigations, book 5, chap. A6, 181 p.

Garbarino, J.R., Kanagy, L.K., and Cree, M.E., 2006, Determination of elements in natural-water, biota, sediment and soil samples using collision/reaction cell inductively coupled plasma-mass spectrometry: U.S. Geological Survey Techniques and Methods, book 5, sec. B, chap.1, 88 p.

GeoTrans, Inc., 1987, A two-dimensional finite-difference flow model simulating the effects of withdrawals to the $\mathrm{N}$ aquifer, Black Mesa area, Arizona: Boulder, Colorado, GeoTrans, Inc., report prepared for Peabody Western Coal Company.

Harshbarger, J.W., Lewis, D.D., Skibitzke, H.E., Heckler, W.L., and Krister, L.R., 1966, Arizona water: U.S. Geological Survey Water-Supply Paper 1648, 85 p.

Hart, R.J., and Sottilare, J.P., 1988, Progress report on the ground-water, surface-water, and quality-of-water monitoring program, Black Mesa area, northeastern Arizona-1987-88: U.S. Geological Survey Open-File Report 88-467, 27 p.

Hart, R.J., and Sottilare, J.P., 1989, Progress report on the ground-water, surface-water, and quality-of-water monitoring program, Black Mesa area, northeastern Arizona-1988-89: U.S. Geological Survey Open-File Report 89-383, 33 p.

Hill, G.W., 1985, Progress report on Black Mesa monitoring program-1984: U.S. Geological Survey Open-File Report 85-483, 24 p.

Hill, G.W., and Sottilare, J.P., 1987, Progress report on the ground-water, surface-water, and quality-of-water monitoring program, Black Mesa area, northeastern Arizona-1987: U.S. Geological Survey Open-File Report 87-458, 29 p.
Hill, G.W., and Whetten, M.I., 1986, Progress report on Black Mesa monitoring program-1985-86: U.S. Geological Survey Open-File Report 86-414, 23 p.

HSIGeoTrans, Inc., 1993, Investigation of the N- and D-aquifer geochemistry and flow characteristics using major ion and isotopic chemistry, petrography, rock stress analyses, and dendrochronology in the Black Mesa area, Arizona: Boulder, Colo., HSIGeoTrans, Inc., report prepared for Peabody Coal Company, 400 p.

HSIGeoTrans, Inc., and Waterstone Environmental Hydrology and Engineering, Inc., 1999, A three-dimensional flow model of the D and N aquifers, Black Mesa Basin, Arizona: Boulder, Colo., HSIGeoTrans, Inc., and Waterstone Environmental Hydrology and Engineering, Inc., report prepared for Peabody Western Coal Company, 75 p.

Kister, L.R., and Hatchett, J.L., 1963, Selected chemical analyses of the ground water, part 2 of Geohydrologic data in the Navajo and Hopi Indian Reservations, Arizona, New Mexico, and Utah: Arizona State Land Department Water-Resources Report 12-B, 58 p.

Koterba, M.T., Wilde, F.D., and Lapham, W.W., 1995, Groundwater data-collection protocols and procedures for the National Water-Quality Assessment Program- Collection and documentation of water-quality samples and related data: U.S. Geological Survey Open-File Report 95-399, 113 p.

Lane, S.L., Flanagan, Sarah, and Wilde, F.D., 2003, Selection of equipment for water sampling (ver. 2.0): U.S. Geological Survey Techniques of Water-Resources Investigations, book 9, chap. A2, March 2003, available at http://pubs.water.usgs. gov/twri9A2.

Littin, G.R., 1992, Results of ground-water, surface-water, and water-quality monitoring, Black Mesa area, northeastern Arizona-1990-91: U.S. Geological Survey WaterResources Investigations Report 92-4045, 32 p.

Littin, G.R., 1993, Results of ground-water, surface-water, and water-quality monitoring, Black Mesa area, northeastern Arizona-1991-92: U.S. Geological Survey WaterResources Investigations Report 93-4111, 23 p.

Littin, G.R., Baum, B.M., and Truini, Margot, 1999, Groundwater, surface-water, and water-chemistry data, Black Mesa area, northeastern Arizona_-1997: U.S. Geological Survey Open-File Report 98-653, 27 p.

Littin, G.R., and Monroe, S.A., 1995a, Results of ground-water, surface-water, and water-quality monitoring, Black Mesa area, northeastern Arizona-1992-93: U.S. Geological Survey Water-Resources Investigations Report 95-4156, 37 p.

Littin, G.R., and Monroe, S.A., 1995b, Results of ground-water, surface-water, and water-chemistry monitoring, Black Mesa area, northeastern Arizona-1994: U.S. Geological Survey Water-Resources Investigations Report 95-4238, 25 p. 
Littin, G.R., and Monroe, S.A., 1996, Ground-water, surfacewater, and water-chemistry data, Black Mesa area, northeastern Arizona-1995: U.S. Geological Survey Open-File Report 96-616, 22 p.

Littin, G.R., and Monroe, S.A., 1997, Ground-water, surfacewater, and water-chemistry data, Black Mesa area, northeastern Arizona-1996: U.S. Geological Survey Open-File Report 97-566, $27 \mathrm{p}$.

Lopes, T.J., and Hoffmann, J.P., 1997, Geochemical analyses of ground-water ages, recharge rates, and hydraulic conductivity of the N Aquifer, Black Mesa area, Arizona: U.S. Geological Survey Water-Resources Investigations Report 96-4190, $42 \mathrm{p}$.

Macy, J.P., 2009, Groundwater, surface-water, and waterchemistry data, Black Mesa area, northeastern Arizona-2007-2008: U.S. Geological Survey Open-File Report 2009-1148, 43 p.

Macy, J.P., 2010, Groundwater, surface-water, and waterchemistry data, Black Mesa area, northeastern Arizona-2008-2009: U.S. Geological Survey Open-File Report 2010-1038, 43 p.

McCormack, H.F., Fisk, G.G., Duet, N.R., Evans, D.W., and Castillo, N.K., 2002, Water-resources data, Arizona, water year 2001: U.S. Geological Survey Water-Data Report AZ-01-1, 399 p.

McCormack, H.F., Fisk, G.G., Duet, N.R., Evans, D.W., Roberts, W.P., and Castillo, N.K., 2003, Water-resources data, Arizona, water year 2002: U.S. Geological Survey WaterData Report AZ-02-1, 337 p.

Smith, C.F., Anning, D.W., Duet, N.R., Fisk, G.G., McCormack, H.F., Pope, G.L., Rigas, P.D., and Wallace, B.L., 1995, Water-resources data, Arizona, water year 1994: U.S. Geological Survey Water-Data Report AZ-94-1, 320 p.

Smith, C.F., Boner, F.C., Davis, R.G., Duet, N.R., and Rigas, P.D., 1993, Water-resources data, Arizona, water year 1992: U.S. Geological Survey Water-Data Report AZ-92-1, 360 p.

Smith, C.F., Duet, N.R., Fisk, G.G., McCormack, H.F., Partin, C.K., Pope, G.L., Rigas, P.D., and Tadayon, Saeid, 1996, Water-resources data, Arizona, water year 1995: U.S. Geological Survey Water-Data Report AZ-95-1, 306 p.

Smith, C.F., Duet, N.R., Fisk, G.G., McCormack, H.F., Partin, C.K., Pope, G.L., and Rigas, P.D., 1997, Water-resources data, Arizona, water year 1996: U.S. Geological Survey Water-Data Report AZ-96-1, 328 p.

Smith, C.F., Rigas, P.D., Ham, L.K., Duet, N.R., and Anning, D.W., 1994, Water-resources data, Arizona, water year 1993: U.S. Geological Survey Water-Data Report AZ-93-1, 360 p.

Sottilare, J.P., 1992, Results of ground-water, surface-water, and water-quality monitoring, Black Mesa area, northeastern Arizona-1989-90: U.S. Geological Survey WaterResources Investigations Report 92-4008, 38 p.
Struzeski, T.M., DeGiacomo, W.J., and Zayhowski, E.J., 1996, Methods of analysis by the U.S. Geological Survey National Water Quality Laboratory - Determination of dissolved aluminum and boron in water by inductively coupled plasmaatomic emission spectrometry: U.S. Geological Survey Open-File Report 96-149, 17 p.

Tadayon, Saeid, Duet, N.R., Fisk, G.G., McCormack, H.F., Partin, C.K., Pope, G.L., and Rigas, P.D., 1999, Waterresources data, Arizona, water year 1998: U.S. Geological Survey Water-Data Report AZ-98-1, 454 p.

Tadayon, Saeid, Duet, N.R., Fisk, G.G., McCormack, H.F., Partin, C.K., Pope, G.L., and Rigas, P.D., 2000, Waterresources data, Arizona, water year 1999: U.S. Geological Survey Water-Data Report AZ-99-1, 389 p.

Tadayon, Saeid, Duet, N.R., Fisk, G.G., McCormack, H.F., Partin, C.K., Pope, G.L., and Rigas, P.D., 2001, Waterresources data, Arizona, water year 2000: U.S. Geological Survey Water-Data Report AZ-00-1, 390 p.

Tadayon, Saeid, Duet, N.R., Fisk, G.G., McCormack, H.F., Pope, G.L., and Rigas, P.D., 1998, Water-resources data, Arizona, water year 1997: U.S. Geological Survey Water-Data Report AZ-97-1, 416 p.

Thomas, B.E., 2002a, Ground-water, surface-water, and water-chemistry data, Black Mesa area, northeastern Arizona-2000-2001, and performance and sensitivity of the 1988 USGS numerical model of the N aquifer: U.S. Geological Survey Water-Resources Investigations Report 02-4211, 75 p.

Thomas, B.E., 2002b, Ground-water, surface-water, and water-chemistry data, Black Mesa area, northeastern Arizona-2001-02: U.S. Geological Survey Open-File Report $02-485,43 \mathrm{p}$.

Thomas, B.E., and Truini, Margot, 2000, Ground-water, surface-water, and water-chemistry data, Black Mesa area, northeastern Arizona-1999: U.S. Geological Survey Open-File Report 00-453, 42 p.

Truini, Margot, Baum, B.M., Littin, G.R., and ShingoitewaHonanie, Gayl, 2000, Ground-water, surface-water, and waterchemistry data, Black Mesa area, northeastern Arizona-1998: U.S. Geological Survey Open-File Report 00-66, 37 p.

Truini, Margot, and Longsworth, S.A., 2003, Hydrogeology of the D aquifer and movement and ages of ground water determined from geochemical and isotopic analyses, Black Mesa area, northeastern Arizona: U.S. Geological Survey Water-Resources Investigations Report 03-4189, 38 p.

Truini, Margot, and Macy, J.P., 2005, Lithology and thickness of the Carmel Formation as related to leakage between the D and N aquifer, Black Mesa, Arizona: U.S. Geological Survey Scientific Investigations Report 2005-5187, 7 p. 
Truini, Margot, and Macy, J.P., 2006, Ground-water, surfacewater, and water-chemistry data, Black Mesa area, northeastern Arizona-2004-05: U.S. Geological Survey Open-File Report 2006-1058, 42 p.

Truini, Margot, and Macy, J.P., 2007, Ground-water, surfacewater, and water-chemistry data, Black Mesa area, northeastern Arizona-2005-06: U.S. Geological Survey Open-File Report 2007-1041, 42 p.

Truini, Margot, and Macy, J.P., 2008, Ground-water, surfacewater, and water-chemistry data, Black Mesa area, northeastern Arizona-2006-07: U.S. Geological Survey Open-File Report 2008-1324, 33 p.

Truini, Margot, Macy, J.P., and Porter T.J., 2005, Groundwater, surface-water, and water-chemistry data, Black Mesa area, northeastern Arizona-2003-04: U.S. Geological Survey Open-File Report 2005-1080, 44 p.

Truini, Margot, and Thomas, B.E., 2004, Ground-water, surface-water, and water-chemistry data, Black Mesa area, northeastern Arizona - 2002-03: U.S. Geological Survey Open-File Report 03-503, 43 p.

U.S. Department of Agriculture, Natural Resources Conservation Service, 1999, Arizona annual precipitation: Fort Worth, Texas, USDA-NRCS National Cartography \& Geospatial Center, scale 1:1,300,000.

U.S. Environmental Protection Agency, 2003, Current drinking water standards, national primary and secondary drinking water regulations: Washington, D.C., U.S. Environmental Protection Agency, accessed October 5, 2010, at http:// www.epa.gov/safewater/mcl.html 08:30A.

U.S. Geological Survey, 1963-64a, Surface-water records of Arizona: $91 \mathrm{p}$.

U.S. Geological Survey, 1963-64b, Ground-water records of Arizona: $80 \mathrm{p}$.

U.S. Geological Survey, 1965-74a, Water-resources data for Arizona-Part 1, surface-water records: 212 p.

U.S. Geological Survey, 1965-74b, Water-resources data for Arizona-Part 2, ground-water records: $89 \mathrm{p}$.

U.S. Geological Survey, 1976-83, Water-resources data for Arizona, water years 1975-81: U.S. Geological Survey WaterData Reports AZ-75-1 to AZ-81-1, [pagination varies].

U.S. Geological Survey, 1978, Progress report on Black Mesa monitoring program - 1977: U.S. Geological Survey OpenFile Report 78-459, 38 p.

U.S. Geological Survey, 2006, Collection of water samples (ver. 2.0): U.S. Geological Survey Techniques of WaterResources Investigations, book 9, chap. A4, September 2006, available at http://pubs.water.usgs.gov/twri9A4/.
White, N.D., and Garrett, W.B., 1984, Water resources data, Arizona, water year 1982: U.S. Geological Survey Water-Data Report AZ-82-1, 440 p.

White, N.D., and Garrett, W.B., 1986, Water resources data, Arizona, water year 1983: U.S. Geological Survey Water-Data Report AZ-83-1, 387 p.

White, N.D., and Garrett, W.B., 1987, Water resources data, Arizona, water year 1984: U.S. Geological Survey Water-Data Report AZ-84-1, 381 p.

White, N.D., and Garrett, W.B., 1988, Water resources data, Arizona, water year 1985: U.S. Geological Survey Water-Data Report AZ-85-1, 343 p.

Wilde, F.D., ed., variously dated, Field measurements: U.S. Geological Survey Techniques of Water-Resources Investigations, book 9, chap. A6, with sec. 6.0-6.8, available at http://pubs.water.usgs.gov/twri9A6/[

Wilde, F.D., 2005, Preparations for water sampling: U.S. Geological Survey Techniques of Water-Resources Investigations, book 9, chap. A1, January 2005, available at http:// pubs.water.usgs.gov/twri9A1/.

Wilde, F.D., ed., 2004, Cleaning of Equipment for water sampling (ver. 2.0): U.S. Geological Survey Techniques of Water-Resources Investigations, book 9, chap. A3, April 2004, available at http://pubs.water.usgs.gov/twri9A3/ .

Wilde, F.D., Radtke, D.B., Gibs, Jacob, and Iwatsubo, R.T., eds., 2004 with updates through 2009, Processing of water samples (ver. 2.2): U.S. Geological Survey Techniques of Water-Resources Investigations, book 9, chap. A5, April 2004, available at http://pubs.water.usgs.gov/twri9A5/.

Wilson, R.P., and Garrett, W.B., 1988, Water resources data, Arizona, water year 1986: U.S. Geological Survey Water-Data Report AZ-86-1, 341 p.

Wilson, R.P., and Garrett, W.B., 1989, Water-resources data, Arizona, water year 1987: U.S. Geological Survey Water-Data Report AZ-87-1, 385 p.

Zhu, Chen; Waddell, R.K., Jr.; Star, Ira; and Ostrander, Murray, 1998, Responses of ground water in the Black Mesa basin, northeastern Arizona, to paleoclimatic changes during the late Pleistocene and Holocene: Geology, v. 26, no. 2, p. $127-130$.

Zhu, Chen, 2000, Estimate of recharge from radiocarbon dating of groundwater and numerical flow and transport modeling: Water Resources Research, v. 36, no. 9, p. 2607-2620. 
Produced in the Western Region, Menlo Park, California Manuscript approved for publication, June 24, 2011

Edited by Tracey Suzuki

Layout and Design by Jeanne S. DiLeo 
